This volume is a product of the staff of the International Bank for Reconstruction and Development / The World Bank. The World Bank does not guarantee the accuracy of the data included in this work. The findings, interpretations, and conclusions expressed in this paper do not necessarily reflect the views of the Executive Directors of the World Bank or the governments they represent.

The material in this publication is copyrighted.

\title{
FinANCIAL SECTOR ASSESSMENT PROGRAM
}

\section{REPUBLIC OF INDONESIA}

\section{BASEL CORE PRINCIPLES ASSESSMENT}

\section{DETAILED ASSESSMENT OF COMPLIANCE}

\section{DECEMBER 2010}

THE WORLD BANK

FINANCIAL AND PRIVATE SECTOR DEVELOPMENT

VICE PRESIDENCY

EAST ASIA AND PACIFIC REGION VICE PRESIDENCY
INTERNATIONAL MONETARY FUND MONETARY AND CAPITAL MARKETS DEPARTMENT 
I. Summary, Principal Comments, and Recommendations..........................................

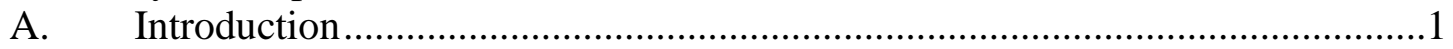

B. Information and Methodology Used .......................................................

C. Overview of the Institutional and Macro-economic Framework and the Structure of the Financial Markets.............................................................................

D. Review of the Preconditions for Effective Banking Supervision .....................4

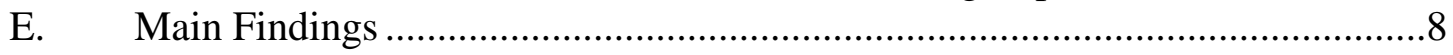

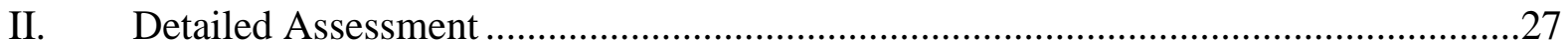

Tables

1. Summary Compliance with the Basel Core Principles - ROSCs ............................................12

2. Summary Compliance with the Basel Core Principles —-Detailed ...........................................17

3. Recommended Plan of Action to Improve Compliance with the Basel...................................22

4. Detailed Assessment of Compliance with the Basel Core Principles.......................................29 


\section{ACRONYMS AND ABBREVIATIONS}

$\begin{array}{ll}\text { AMA } & \text { Advanced measurement approach } \\ \text { AML } & \text { Anti-money laundering } \\ \text { AFS } & \text { Available for sale } \\ \text { Bapepam-LK } & \text { Indonesian regulator for NBFIs } \\ \text { BCBS } & \text { Basel Committee on Banking Supervision } \\ \text { BCP } & \text { Basel Core Principles for Effective Banking Supervision } \\ \text { BI } & \text { Bank Indonesia } \\ \text { BIA } & \text { Basic indicator approach } \\ \text { BoC } & \text { Board of Commissioners } \\ \text { BoD } & \text { Board of Directors } \\ \text { C } & \text { Compliant } \\ \text { CAMELS } & \text { A bank supervisory rating methodology } \\ \text { CD } & \text { Compliance director } \\ \text { CDD } & \text { Customer due diligence } \\ \text { CFP } & \text { Contingency funding plan } \\ \text { CFT } & \text { Combating the financing of terrorism } \\ \text { CP } & \text { Core Principle } \\ \text { DSAK } & \text { Indonesian Financial Accounting Standards Board } \\ \text { DTA } & \text { Deferred tax assets } \\ \text { EaR } & \text { Earnings at risk } \\ \text { EC } & \text { Essential criterion } \\ \text { ELA } & \text { Emergency liquidity assistance } \\ \text { EVE } & \text { Economic value of equity } \\ \text { FASB } & \text { Federal Accounting Standards Board } \\ \text { FATF } & \text { Financial Action Task Force } \\ \text { FDIC } & \text { Federal Deposit Insurance Corporation (US) } \\ \text { FSAP } & \text { Financial Sector Assessment Program } \\ \text { FSSK } & \text { Financial System Stability Forum } \\ \text { FSSN } & \text { Financial system safety net } \\ \text { GCG } & \text { Good corporate governance } \\ \text { GDP } & \text { Gross Domestic Product } \\ \text { GoI } & \text { Government of Indonesia } \\ \text { HR } & \text { Human resources } \\ \text { IAI } & \text { Indonesian Institute of Accountants } \\ \text { IAS } & \text { International accounting standard } \\ \text { IDIC or LPS } & \text { Indonesia Deposit Insurance Corporation } \\ \text { IDR } & \text { Indonesian Rupiah } \\ \text { IFRS } & \text { International financial reporting standards } \\ \text { IRB } & \text { Internal ratings based } \\ \text { IRRBB } & \text { Interest rate risk in the banking book } \\ \text { IT } & \text { Information technology } \\ \text { KYB } & \text { Know your bank } \\ \text { KYC } & \text { Know your customer } \\ \text { LC } & \text { Largely compliant } \\ & \end{array}$




$\begin{array}{ll}\text { LDR } & \text { Loan to deposit ratio } \\ \text { LLL } & \text { Legal lending limit } \\ \text { MDA } & \text { Multilateral development agency } \\ \text { MIS } & \text { Management information system } \\ \text { ML } & \text { Money laundering } \\ \text { MNC } & \text { Materially non compliant } \\ \text { MOF } & \text { Ministry of Finance } \\ \text { MOU } & \text { Memorandum of understanding } \\ \text { MTM } & \text { Mark to market } \\ \text { NBFI } & \text { Non bank financial institution } \\ \text { NC } & \text { Non compliant } \\ \text { NIM } & \text { Net interest margin } \\ \text { NOP } & \text { Net open position } \\ \text { NPL } & \text { Non-performing loans } \\ \text { NPV } & \text { Net present value } \\ \text { OR } & \text { Operational risk } \\ \text { PAPI } & \text { Indonesian banking accounting guidelines } \\ \text { PEP } & \text { Politically exposed person } \\ \text { PPPATK } & \text { Indonesian Financial Transactions Reporting and Analysis Center } \\ & \text { (Indonesian Financial Intelligence Unit) } \\ \text { PSAK } & \text { Financial accounting standards statement } \\ \text { ROA } & \text { Return on assets } \\ \text { ROSC } & \text { Report on the Observance of Standards and Codes } \\ \text { SA } & \text { Standardized approach } \\ \text { SBIs } & \text { BI bonds } \\ \text { SID } & \text { Debtor information system } \\ \text { SIMWAS } & \text { Surveillance management information system } \\ \text { SOE } & \text { State owned enterprise } \\ \text { STR } & \text { Suspicious transaction report } \\ \text { TF } & \text { Terrorist financing } \\ \text { USD } & \text { US Dollar } \\ \text { VaR } & \text { Value at risk } \\ \end{array}$




\section{Summary, Principal Comments, And Recommendations}

\section{A. Introduction}

1. The Indonesian financial sector comprises banks, multi-finance companies, capital market companies, insurance companies, and pension funds. The banking sector accounts for about 80 percent of the financial sector assets. It is dominated by 121 commercial banks, which account for about 98.6 percent of total banking assets (including 5 sharia banks accounting for 1.8 percent market share), with rural banks comprising the remainder of the banking system (about 1.4 percent market share). Bank Indonesia (BI), the central bank, is responsible for regulation and supervision of the banking system.

\section{B. Information and Methodology Used}

2. The assessment of compliance with the Basel Core Principles for Effective Banking Supervision (BCP) was carried out within the framework of the Financial Sector Assessment Program (FSAP) between September 29 and October 16, 2009. The assessment was conducted by a team comprising Damodaran Krishnamurti (senior financial sector specialist, World Bank), and William Ryback (consultant, International Monetary Fund). The team used the October 2006 Core Principles Methodology document of the Basel Committee on Banking Supervision (BCBS), but by agreement with BI the team limited its work to a study of the essential criteria. In view of the small share of sharia and rural banks, the assessment was confined to regulation and supervision as applicable to commercial banks.

3. BI performed a self-assessment of its compliance with the $\mathrm{BCP}$, and also responded to the questionnaire on banking supervision that had been sent to it prior to the mission. The examiners studied the laws and regulations governing the BI, banking activity in Indonesia, and its supervision. The mission had numerous meetings with senior BI officials involved in licensing, regulation, and supervision of banks (including BI supervisors); senior officials of six selected banks (from the public sector, the private sector, and foreign banks); and representatives of the Indonesian bankers' association, FITCH ratings, Ernst \& Young, and the Indonesian Financial Intelligence Unit (PPATK). The assessors have also relied on (i) the findings of the ROSC on Accounting and Auditing (2009), and (ii) the Asia / Pacific Group on Money Laundering's (APG's) $2^{\text {nd }}$ Mutual Evaluation Report (July 2008) on the level of compliance of the Indonesian anti-money laundering and combating the financing of terrorism (AML / CFT) regime with the AML and CFT standard. All parties involved, and more particularly the BI representatives, cooperated to the fullest extent with the assessors. The assessors are grateful for the significant inputs from all stakeholders, which have helped them in the assessment.

\section{Overview of the Institutional and Macro-economic Framework and the Structure of the Financial Markets}

4. During 2008, the performance of the Indonesian economy remained satisfactory amid global turmoil. Overall economic growth reached 6.1 percent in 2008, slightly below the 6.3 percent recorded in the previous year. However, in the last quarter of 2008, the economy began to slow in all sectors, with the tradable sectors worst affected due to the fall in global 
demand. The increasing integration of the global economy and the slowing of economies across all countries during 2009 have impacted Indonesia also. BI projects a drop in economic growth in 2009 to around $4.0 \%$ with downside risk if the global economic downturn is greater than predicted.

\section{Indonesia fared fairly well in the external sector during 2008 , despite the slowing} growth in the global economy. Indonesia's exports managed a 9.5 percent growth in 2008 , while imports grew by 10.0 percent. For 2008, the estimated balance of payments deficit was USD 5.3 billion and the current account surplus was USD 0.1 billion. At end- December 2008, international reserves stood at USD 51.6 billion. This represented a level equivalent to 4.0 months of imports and servicing of official debt. For the most part, the rupiah maintained relative stability until mid-September 2008. Thereafter, the deteriorating global crisis put pressure on the rupiah causing it to fall 15.5 percent. However, looking at 2008 overall, the average value of the rupiah depreciated by only 5.4 percent vis-à-vis the US Dollar.

6. The responsibility for supervising the financial sector in Indonesia is shared largely between two institutions. The responsibilities and objectives of each of the authorities are clearly defined in the relevant legislation. BI, the central bank, has authority to regulate and supervise the banking sector, and Bapepam-LK is authorized to regulate and supervise the leasing and finance companies, insurance companies, pension funds, and securities companies. The primary role of the Indonesia Deposit Insurance Corporation (IDIC/LPS) is to insure customer deposits in banks and carry out the resolution of failed banks. An amendment to the BI Act in 2004 envisages establishment of a supervisory board as a separate entity by December 31, 2010 to conduct supervision of banks and other financial services companies, including insurance companies, pension funds, securities companies, venture capital firms, finance companies, and other entities operating in the management of funds from the public. As the details of the establishment of this new supervisory entity are unclear, this assessment is confined to the bank supervisory framework in effect at the time of the assessment.

7. BI draws its mandate for regulation and supervision of the banking system from the provisions of two major acts - (i) the Act of the Republic of Indonesia Number 7 of 1992 concerning Banking, as amended by the Act of the Republic of Indonesia Number 10 of 1998, (the Banking Act); and (ii) the Act of the Republic of Indonesia Number 23 of 1999 concerning Bank Indonesia, as amended by Act of the Republic of Indonesia Number 3 of 2004 (the BI Act). BI's independence is contained in the BI Act, which also requires annual disclosure to the public along with intended goals and financial reporting. Though BI's operational budget needs parliamentary approval, it does not appear to be constrained in performing its regulatory or supervisory functions. The BI has sufficient powers to ensure compliance with laws, regulations, prudential standards, and guidelines.

8. Indonesia's financial system is dominated by the banking sector, which represents approximately 80 percent of total financial sector assets. Other players in the financial industry, such as insurance companies, pension funds, finance companies, securities companies, and pawn shops, have small shares within the market. 


Financial System - Market share (Assets) (\%)
\begin{tabular}{|l|r|}
\hline Commercial Banks & 79.5 \\
\hline Rural Banks & 1.1 \\
\hline Insurance Companies & 8.8 \\
\hline Pension Funds & 3.1 \\
\hline Finance Companies & 4.4 \\
\hline Securities Companies & 2.7 \\
\hline Pawn Shops & 0.4 \\
\hline Source: Bl's Financial Stability Review No.13, September 2009 \\
\hline
\end{tabular}

9. At end-September 2009, there were 121 commercial banks (98.6 percent market share) and 1,765 rural banks (1.4 percent market share) under BI's supervision. The commercial banks consist of 4 state banks, 26 regional government banks, 86 private banks (including 16 joint venture banks, 16 significantly foreign owned local banks, and branches of 10 foreign banks), and 5 Sharia banks. The 30 state owned banks (including Bank Mandiri, Indonesia's largest bank) account for about 45 percent market share in the banking sector. Foreign banks (including branches, joint venture banks, and significantly foreign owned local banks) have about 30 percent market share. In contrast, Sharia banks hold a relatively small portion of assets within the banking industry (about 2 percent). While fourteen major banks account for about 70 percent market share, the share of the top 5 banks is about 50 percent.

Indonesian Banking Sector (September 2009)

\begin{tabular}{|c|c|c|}
\hline Bank & Number & $\begin{array}{l}\text { Market share in } \\
\text { assets ( percent) }\end{array}$ \\
\hline Commercial banks & 121 & 98.6 \\
\hline $\begin{array}{ll}\text { - } & \text { State owned banks (including regional } \\
\text { government banks) }\end{array}$ & 30 & 45.2 \\
\hline $\begin{array}{l}\text { Foreign banks (including } 10 \text { foreign bank } \\
\text { branches, joint venture banks and } \\
\text { significantly foreign owned local banks) }\end{array}$ & 42 & 30.0 \\
\hline - $\quad$ Private banks & 44 & 23.0 \\
\hline Sharia banks & 5 & 1.8 \\
\hline Rural banks & 1,765 & 1.4 \\
\hline Source: Bank Indonesia & & \\
\hline
\end{tabular}

10. In 2008, the banking industry performed well, despite significant pressures from the global market turmoil. The relatively high levels of capital adequacy combined with credit expansion underpin the performance of the banking industry, as reflected in its profitability. The global crisis did not directly impact the Indonesian banking system as it mainly conducts "conservative and traditional" banking activities. Their source of funds is primarily deposits (78 percent of liabilities), shareholder funds (10 percent), and dues to banks and BI (6 percent). The deployment of funds is credit (57 percent of assets), BI (13 percent), government securities (13 
percent), and cash and bank balances (13 percent). Banks' exposure to equities is limited by regulations. Indonesian banks' risk profile mainly consists of credit risk as banking activities focus on the credit area.

11. The Indonesian banking system's performance indicators reflect a relatively healthy and sound banking system. The capital ratio of banks was well above the regulatory minimum, but had declined slightly in 2008 due to strong credit expansion. In addition, other performance indicators for commercial banks, such as profitability and liquidity, are also relatively good despite the pressure from global risk. In September 2009, the total assets of commercial banks reached IDR 2,386 trillion (approximately USD 239 billion). The main indicators of the health of the Indonesian banking industry are given below:

Banking Sector - Performance parameters

\begin{tabular}{|l|c|c|c|}
\hline Parameter & Dec 2007 & Dec 2008 & Sep 2009 \\
\hline $\begin{array}{l}\text { Total assets } \\
\text { (IDR Trillion) }\end{array}$ & 1,987 & 2,311 & 2,386 \\
\hline Total assets as percent of GDP & 50.3 & 46.6 &.. \\
\hline Capital adequacy ratio & 19.3 & 16.2 & 17.9 \\
\hline Gross NPL ratio & 4.6 & 3.8 & 3.9 \\
\hline Net NPL ratio & 1.9 & 1.5 & 1.7 \\
\hline Credit growth (\%) & 26.5 & 30.5 & 4.4 \\
\hline Loan to Deposit ratio & 69.2 & 77.2 & 73.6 \\
\hline $\begin{array}{l}\text { Liquid assets (as percent of total } \\
\text { deposits) }\end{array}$ & 30.1 & 25.8 & 26.1 \\
\hline NIM & 5.7 & 5.4 & 5.4 \\
\hline ROA & 2.8 & 2.3 & 2.6 \\
\hline Source: Bank Indonesia & & & \\
\hline
\end{tabular}

12. Within BI, bank regulation and supervision are conducted by several directorates. Commercial bank regulations, including licensing, are handled in two Directorates, while supervision, including investigation, is handled in four Directorates. Regulation and supervision of the Islamic banks and the rural banks are handled in two dedicated Directorates. In all, the eight directorates dealing with the banking system report directly to the Board of Governors through three Deputy Governors.

\section{Review of the Preconditions for Effective Banking Supervision}

\section{Quality of supervision relies not only on the supervisory institution, but also on the} establishment of certain preconditions. These include sound and sustainable macroeconomic policies; a well-developed public infrastructure; effective market discipline; and mechanisms for providing an appropriate level of systemic protection. While these are largely beyond the control of the supervisor, nevertheless they significantly affect the supervisor's ability to conduct effective supervision. 


\section{Macroeconomic policies}

14. BI contributes to sustaining macroeconomic soundness by maintaining a stable internal and external value of the Rupiah. This objective is pursued by implementing effective monetary policies, and conducting effective bank supervision. Under the inflation targeting framework that the BI follows, it can establish intermediate targets, including interest rates, use an array of monetary instruments, including: (i) open market operations in the rupiah and foreign exchange money markets; (ii) statutory reserve requirements; and (iii) regulations for credit or financing. BI can also operate monetary instruments on Sharia principles. BI sets the BI rate (overnight rate), conducts monetary operations, and uses standing facilities to achieve the inflation target, which is set by the government in consultation with BI.

\section{The sustainability and soundness of macroeconomic policies have been demonstrated.}

Despite the severe slowdown in the global economy due to the global financial crisis, Indonesia's economy experienced 6.1 percent growth in 2008, which is better than most countries in the region and is only slightly below the growth during 2007 (6.3 percent). BI has taken initiatives to prevent an increase in banking system risks due to the deteriorating economy, including increased monitoring. Additionally, several policies have been initiated or amended to maintain financial stability through regulations including a limitation on speculative currency transactions involving the Indonesian Rupiah (IDR), an emergency credit facility, a short-term credit facility, and a reduction of the BI rate.

\section{Public infrastructure}

16. There are several weaknesses in the accounting and auditing standards and practices in Indonesia. The Indonesian financial accounting standards are mandatorily applicable for financial reporting by public companies, banks, and financial institutions. The Indonesian Institute of Accountants (IAI) is the professional body of accountants and the Indonesian Institute of Public Accountants (IAPI) is the professional body for public accountants. The IAPI is an association member of IAI. The IAI develops and disseminates accounting standards through the Indonesian Financial Accounting Standards Board (DSAK), and IAPI develops and disseminates audit and ethics standards in line with international good practice. A recent ROSC assessment reveals several weaknesses in the accounting and auditing standards and practices in Indonesia, a few of which are mentioned below. This has implications for the quality of audited financial information used by market participants in Indonesia.

- Although most financial accounting standards statement (PSAK) are based on international financial reporting standards (IFRS), gaps in the standards still exist. 23 PSAK are uniquely local standards with no counterpart in IFRS; 8 PSAK have no gaps with IFRS; 19 PSAK have minor gaps with IFRS; and 2 PSAK have moderate gaps with IFRS.

- The auditing standard setter, IAPI, has expressed the intention to converge local auditing standards with International Standards on Auditing (ISA) by 2011; however, no practical arrangement has yet been put in place for achieving this goal.

- Since internationally comparable accounting and reporting requirements for financial instruments are not being implemented, the reported results and financial condition of banks and similar financial institutions tend to be distorted. 
- A review of the financial statements of selected companies revealed gaps in compliance with the PSAKs, including gaps in the area of segment information, related party transactions, consolidated financial statements, employee benefits, and derivative transactions.

- Instances of practicing accountants and auditors giving in to undue pressure from corporate management, leading to compliance with standards "in appearance" rather than "in substance", were observed.

- There is no mechanism to proactively ensure that practicing accountants and auditors comply with the requirements of the code of ethics for professional accountants.

- Of the more than 400 accounting firms in the country, only 6 to 8 firms appear to have a very high level of compliance with the applicable auditing standards. The small and medium-size audit practices generally lack the necessary resources to put in place arrangements for audit quality control.

17. The payment and settlement system, managed by BI, provides the industry with a real time gross settlement system in addition to a standard clearing process. BI set up a Debtor Information System (SID) in June 2006, in which bank participation is mandatory but NBFI participation is optional. Despite an MOU signed with the MOF to mandate the NBFIs to participate, the result has been weak. At present, all 121 commercial banks, 576 of the 1765 rural banks with assets of more than IDR 10 billion (1200 of the 3454 rural offices), and seven finance companies are participating.

\section{The legal framework and accompanying enforcement machinery needs to be} strengthened. Shortcomings in the system of corporate, bankruptcy, contract, and private property laws, their consistent enforcement, the reliability of the legal profession, and the effectiveness and reliability of the judiciary can seriously undermine the quality and effectiveness of banking supervision. Though the legal framework relevant for the financial system of Indonesia has undergone substantive improvement in the last decade, including the passage of improved bankruptcy laws, there are weaknesses in the enforcement of collateral and creditor rights that are reflected in poor recovery rates. According to the World Bank Doing Business indicators, Indonesia exhibits one of the lowest recovery rates in the region at below 15 percent and the cost of bankruptcy procedures is about 18 percent of the estate. In addition, due to lengthy court proceedings, bankruptcies in Indonesia take between 5 and 6 years to be resolved. Enforcement of contracts takes about 570 days and the associated costs are about 123 percent of the claim. The Indonesian legal system is still characterized by (a) inadequacies, absence, and overlaps observed in certain laws; (b) difficulties in enforcement of movable securities; and (c) difficulties in enforcement of legal rights, especially in unsecured lending. Banks are generally seen to be hesitant to resort to the court process because of the unpredictability of legal decisions in the court. While progress has been made since the advent of recent legal reforms, the capacity and professionalism of the implementing institutions and the level of recovery reflect the lack of efficient administration to deal with rehabilitation and insolvency. Arbitration is generally resorted to, but does not seem to be an attractive option as the court's assistance is ultimately required for enforcement of the award. 


\section{Market Discipline}

\section{BI regulations seek to establish good corporate governance and internal control} functions in banks and a minimum set of disclosures. BI regulations require banks to ensure implementation of good corporate governance (GCG) principles in each business activity at all organizational levels or hierarchy. BI regulations also require banks to ensure the creation, maintenance, and oversight of an effective internal control mechanism. In an effort to establish market discipline, BI has published a regulation concerning minimum disclosure by banks, which includes ownership details, strategies and management policies, a set of audited financial statements, the level of risk exposures, and the risk management procedures implemented by the bank. Additionally, BI has applied an interest rate cap on deposits to be eligible for deposit insurance, with a view to increasing the level of market discipline. The cap is intended to make the market more cautious in their dealings with banks offering very high deposit rates, by making these deposits ineligible for deposit insurance.

\section{Public Safety nets}

20. BI and the Deposit Insurance Corporation (LPS) have strived to set up mechanisms to provide appropriate safety nets. BI has in place a short-term (up to a maximum limit of 90 days) liquidity facility against the collateral of government bonds, BI certificates, and loans classified as 'current' (where the bank does not possess eligible government bonds or BI certificates). This facility is in addition to the traditional central bank overnight and intraday facilities. Thus, as the lender of last resort, BI caters to illiquid, but solvent institutions that are not deemed to be systemically important. For systemically important solvent banks, the emergency liquidity assistance (ELA) facility allows for longer term extensions of credit (up to a maximum limit of 180 days). BI will provide ELA to a solvent bank deemed systemically important only with a guarantee from the Government of Indonesia. The compensation for any losses that may be experienced by BI on such lending will therefore come from the government. Indonesia has a deposit insurance regime that is in line with good international practice, modeled after the U.S. FDIC. The LPS insures deposits and is also responsible for resolving failed banks. In response to the global crisis, the deposit insurance coverage limit was raised in Indonesia from IDR 100 million (USD 10,000) to IDR 2 billion (USD 200,000) in October 2008 to promote financial stability. The revised limit covers about 90 percent of the depositors. The premia for deposit insurance are not risk related, though this is under discussion. Resolution of all failed banks is the responsibility of the LPS.

\section{In the light of its past experience, Indonesia has been developing a crisis management} framework for dealing with financial sector crises. The LPS Law of 2004 established a Coordination Committee comprising the Ministry of Finance, BI, and the LPS to determine the policy for the resolution and handling of a failing bank that is predicted to have a systemic effect. A joint decree by BI, MOF, and the LPS in June 2007 established the Financial System Stability Forum (FSSK) to serve as a forum for cooperation, coordination, and exchange of information at a technical level among the three agencies. This was designed to enhance the agencies' ability to submit the inputs and information required by the Coordination Committee. Pending passage of a law, the President promulgated an Ordinance in lieu of the law in October 2008, establishing the Financial System Stability Committee comprising the Minister of Finance as the Chairperson and Member, and the Governor, Bank Indonesia, as Member. The Committee could determine whether a systemically important financial institution would receive BI emergency liquidity 
assistance, as well as other measures to resolve the troubled institution. This Committee decided on the systemic importance of a bank that was in difficulty during the crisis. The government, in collaboration with BI, drafted a Financial System Safety Net (FSSN) Law to establish in law the Financial System Stability Committee that was created under the above Ordinance. The draft FSSN law was intended to address issues pertaining to institutional coordination in determining the banks and non-bank financial institutions that are considered to have a systemic impact. The draft law contemplated establishing a committee comprising at least the Minister of Finance and the BI Governor to jointly determine which institutions are considered to be systemically important. Crisis prevention measures could be undertaken by providing temporary liquidity assistance or by injecting temporary capital to the bank (or NBFI) bearing a systemic impact and facing a liquidity problem or a solvency problem. The draft law was rejected by the Parliament and the authorities are contemplating resubmission of the bill for establishment of the FSSN. The ordinance promulgated in October 2008 has also since lapsed. In these circumstances, pending passage of the law, the Coordination Committee constituted under the LPS law serves as the mechanism for cooperation and coordination for handling crisis management in the banking sector.

\section{E. Main Findings}

\section{Bank regulation and supervision have come a long way since the late 1990s when} Indonesia faced a banking system crisis. The BI has been continually engaged in improving the regulatory and supervisory frameworks and methodologies with the primary aim of maintaining a healthy banking system that effectively plays its role of financial intermediation. The BI has succeeded in effectively addressing some of the shortcomings that prevailed in the banking system in the late 1990s. It has also consciously focused on improving staff competency, which has helped it to establish credibility among the banking community in Indonesia. Notwithstanding the above, the increasing globalization and integration of the Indonesian economy and financial sector, the challenges posed by the secondary impact of the recent global financial crisis, and the need to equip the Indonesian banking sector to play a more significant role in the country's economy require further improvements in regulation and supervision. A summary of the detailed assessment of compliance with the BCPs is presented below.

\section{Objectives, independence, powers, transparency, and cooperation (principle 1).}

23. BI's responsibilities and powers for regulation and supervision of the Indonesian banking system, including licensing and setting of prudential rules, are spelt out in the Bank Indonesia Act (the BI Act) and the Banking Act. The BI Act requires annual disclosure to the public along with intended goals and financial reporting. BI's independence is contained in the BI Act. Legal provisions do not provide adequate protection to BI as the supervisory authority and the supervisory staff against personal prosecution. Although BI's operational budget needs parliamentary approval, BI does not appear to be constrained in performing its regulatory or supervisory functions. BI has sufficient powers to ensure compliance with laws, regulations, prudential standards, and guidelines.

24. The lack of appropriate gateways for information exchanges with domestic and foreign supervisory authorities is an impediment to BI discharging its legal responsibilities of regulating and supervising the banking system. BI, in an attempt to get around this, uses its authority to examine the operations of domestic subsidiaries when the scope of examination so 
warrants. The inability to have free exchange of information prevents the BI from forming a view on whether the conditions in other domestic financially related sectors are having a serious impact on the banking sector and whether examination and supervisory priorities may need to be altered. In light of the increasing significance of foreign banks in the Indonesian banking system, the absence of formal and informal arrangements for cooperation and coordination with foreign home supervisors of systemically relevant foreign financial institutions could pose significant risk to Indonesia in the payment and interbank settlement system if the parent were to encounter sudden and unexpected problems.

\section{Licensing and structure (principles 2 to 5).}

25. The term "bank" is clearly defined in laws and regulations. The Banking Act clearly defines all permitted banking activities and impermissible activities. Although BI has been designated as the licensing authority under the law, and it has the authority to set the licensing criteria, there has been no application for a banking license since 1999. Law and practice combine to ensure that the term "bank" can be used only by those licensed by BI. BI defines significant ownership as equal to or exceeding 25 percent of the total equity and includes parties acting in concert or otherwise connected. Any transfer of ownership above 5 percent must be reported to BI within 10 days. Any transfer resulting in ownership exceeding 25 percent must be reported to BI for prior approval, and these shareholders are subjected to fit and proper tests. The BI has the authority to enforce divestiture or reject any proposals that hinder appropriate supervision.

26. Regulations require banks to obtain BI's prior approval for investment in the equity of financial entities and do not permit investment in the equity of non-financial entities. The BI regulations apply at the bank level and consequently the equity investments undertaken by the banks' subsidiaries/ group entities are not subjected to scrutiny or review. These regulations are also not applicable to banks' equity investments in entities through the debt resolution route.

\section{Due-diligence requirements and framework (principles 6 to 18).}

27. The Indonesian banking system is at present on Basel I. While the framework is broadly in line with these standards, the more liberal definition of capital, coupled with dilution in risk weights on a few items, has resulted in weaknesses that warrant strengthening. Indonesian banks largely do not use internal methodologies for assessing their overall capital adequacy in relation to their risk profile. There is, to date, little focus on internal models, and perhaps no capacity to validate them. BI's risk management regulations cover credit, market, operational, liquidity, legal, strategic, reputational, and compliance risks. BI is yet to issue regulations on the management of interest rate risk in the banking book (IRRBB) and country / transfer risk. There is scope for improvement in the area of liquidity risk and operational risk management. As the Indonesian banking system is commencing Basel II implementation soon, these aspects gain greater importance. While the Indonesian banking system appears to be compliant with the broad elements of risk management, in reality, a number of individual institutions might not be equipped to manage fully their risk exposures effectively, particularly during adverse conditions, as happened recently when the BI had to step in to help guide the banks. Broad components of the asset classification and provisioning framework applied to delinquent loans are in line with 
international standards, but there are weaknesses in some elements. These could collectively lead to understatement of NPLs, under provisioning, and overstatement of income with implications for capital adequacy, and need to be fixed immediately. These elements need to be reviewed to ensure that the banking system is adequately adjusting capital and provisioning levels to reflect institutional, local, regional, and global conditions. Board oversight of NPL management may need strengthening as there is no evidence that Boards are actively managing the problem assets portfolio.

28. The banking system is governed by the single borrower, borrower group, and related party regulations, which prescribe a prudential cap on these exposures. The regulations are close to international standards, but there are shortcomings in the definition of exposure. As a methodology for management of credit risk, the concept of 'large exposures' and 'portfolio concentrations' are either not practiced or are not practiced adequately.

29. Indonesian banks have a good framework of internal control and compliance functions. While these are governed by comprehensive regulations, BI does not seem to undertake an on-site assessment of the internal control function in its entirety. It is generally assessed indirectly on a piecemeal basis. BI regulations do not explicitly require a risk based audit framework in banks. BI regulations on operational risk (OR) do not explicitly capture the following elements: outsourcing risk; business continuity planning in areas other than IT; legal risk in banks below the regulatory threshold; and supervisory reporting of significant OR events.

30. BI regulations detail the responsibilities and powers of the banking supervisor. Banks are required to file regular compliance reports and BI examiners verify compliance. Reports of transactions that appear suspicious from an AML/CFT point of view are filed with the PPATK. At least annually, supervisors conduct an assessment of the implementation of know your customer (KYC) and AML controls, including management oversight, policies, practices and procedures, internal controls and audit MIS systems, and training. According to the APG's 2008 mutual evaluation report, Indonesia has made significant progress in recent years with its implementation of AML measures, but relatively little implementation of CFT measures has occurred. Significant money laundering (ML) and very significant terrorism and terrorist financing (TF) risks exist in Indonesia. In addition to the domestic laundering of the proceeds of crime, Indonesia notes a particular challenge from the movement of funds to regional financial centers. The customer due diligence (CDD) instruments show some degree of compliance with the FATF recommendations; however, major deficiencies remain, notably in the concept of identification and verification of the beneficial owners, and effective implementation of the regime needs to be further pursued. Indonesia has not established comprehensive controls or oversight over the provision of wire transfers. These are significant shortcomings in AML/CFT preventative measures for the financial system. However, BI has already addressed a few gaps identified by the APG 2008 mutual evaluation through revised regulations.

\section{Bank supervision methods (principles 19 to 21).}

31. BI's supervisory system consists of both off-site and on-site supervision along with regular contacts with bank management. BI has an efficient comprehensive off-site supervisory system that includes receipt and analysis of periodic (daily, weekly, monthly, quarterly, and annual) reports on both a solo and consolidated basis. The integrity of supervisory reports is ensured through on-site verification by supervisors as well as the external auditors. 
While the off-site reports are used well at the single institution level, these are not fully utilized to generate efficient system trends and useful peer group analysis. The absence of formal and informal information sharing arrangements with other financial sector supervisory authorities adversely affects the effectiveness of the bank supervision program. The absence of effective legal protection dampens supervisors' willingness to make decisions and deviate from accepted methods listed in the manual.

32. BI supervisors have developed a fairly good understanding of the operations of individual banks and banking groups. BI has in place a system designed to produce a risk profile of each bank (solo and consolidated banks). The process requires a risk assessment of each institution and a quarterly risk profile assessment that influences the examination plan. Supervisory exercises are carried out in accordance with the risk profile.

\section{Requirements with respect to accounting records and financial reporting (principle 22).}

\section{Regulations require that bank financial statements be based on the Financial} Accounting Standards Statement (PSAK) and Indonesian Banking Accounting Guidelines (PAPI), and that the annual financial statements be audited by a public accountant. Weaknesses in accounting and auditing frameworks in Indonesia have implications. Gaps in the reporting of segment information, related party transactions, consolidated financial statements, employee benefits, and derivative transactions have implications for the quality of disclosures by banks. The introduction of new accounting standards that are aligned to IAS 32 and IAS 39 is likely to pose some challenges to the banking system and the supervisor, and needs close monitoring by BI. Since internationally comparable accounting and reporting requirements for financial instruments are not being implemented, reported results and the financial condition of banks and similar financial institutions tend to be distorted.

\section{Corrective measures (principle 23).}

34. Supervisors have a large arsenal of supervisory tools to resolve problem situations. The range of sanctions covers monetary penalties, administrative sanctions, cease and desist orders, change of management, and revocation of the license. Under normal conditions, BI does not appear hesitant to use its substantial powers to require swift curative action by the banks under its supervision. However, it was not always apparent that proper moderation or escalation was in use. The existing prompt corrective action is largely discretionary and BI tends to allow banks to remain under intensive supervision for several years without resolving the underlying weaknesses.

\section{Supervision on a consolidated basis and international cooperation (principles 24 and 25).}

\section{BI performs its oversight through dedicated teams for each commercial bank.}

Regulatory reports are filed on a solo and consolidated basis allowing for a deeper understanding of where the organization is taking risks. In addition, on-site examinations include, where necessary and prudent, examinations of risk taking in the subsidiaries. Consolidated supervision is being accomplished largely by BI taking responsibility for on-site supervision of the consolidated organization to cover for other financial regulators where routine robust 
examinations are not a part of the supervisory process. Lack of formal arrangements to transfer information between domestic supervisors, combined with weaknesses in the supervision of overseas branches, is a serious impediment to consolidated supervision. Exclusions from the scope of consolidated supervision, non application to the consolidated bank of regulations on equity participation and the sale of structured products, and intra-group transactions where the bank is not directly involved can expose the banks to risks that are currently not within the scope of the supervisor. BI should pay increased attention to the oversight of the foreign operations of Indonesian banks by their management. For example, it was not clear in all cases why Indonesian banks were maintaining a Cayman Island branch. These branches are managed primarily by the New York branch. The reason given by the banks was that the branch allows them to gather funds from the Eurodollar market. Since there are very few, if any, loans priced at LIBOR, it is unusual for banks to need access to that market. Both formal and informal arrangements for ongoing information sharing and coordination with the other supervisors (domestic and foreign) are largely absent and hamper supervisory efforts in many ways. Peer group analysis is not always efficient and useful. At some point, a horizontal examination of a cross-section of banks may be useful to make comparisons and spread best practices throughout the industry.

\section{While BI is making efforts to strengthen home-host relationships and one can expect continued improvements, effective supervision of foreign banks requires continuing monitoring of the parent institution and should include reasonably frequent communication with home supervisors. BI lacks a uniform policy with respect to aligning} supervisory requirements with risks. BI does have arrangements for the exchange of information with close-by neighboring supervisors, but the lines of communication for information exchange are less clear with the home supervisors of systemically relevant foreign financial institutions. The lack of formal and informal gateways for information exchange with the home regulators of systemically relevant foreign financial institutions is a serious issue. The foreign bank community in Indonesia is large and some of the institutions will, no doubt, pose some systemic risk to the system. BI needs to set up a program to identify systemically important foreign institutions, make a determination as to whether the home country supervisor is competent and has the authority to enter into an information sharing agreement, and ensure a regular program of visits to the home supervisors of systemically important foreign banks in Indonesia.

37. A principle-by-principle summary of the assessments is given in Tables 1 and 2.

Table 1. Summary Compliance with the Basel Core Principles-ROSCs

\begin{tabular}{|l|l|}
\hline \multicolumn{1}{|c|}{ Core Principle } & \multicolumn{1}{c|}{ Comments } \\
\hline $\begin{array}{l}\text { 1. Objectives, } \\
\text { independence, powers, } \\
\text { transparency, and } \\
\text { cooperation }\end{array}$ & \\
\hline $\begin{array}{l}1.1 \text { Responsibilities and } \\
\text { objectives }\end{array}$ & $\begin{array}{l}\text { Laws and regulations clearly spell out Bl's responsibilities with respect to the } \\
\text { licensing, prudential standards and requirements, supervision of banks, and } \\
\text { sanctioning powers. Regulations and prudential standards are generally } \\
\text { comprehensive and broadly meet minimum requirements. }\end{array}$ \\
\hline $\begin{array}{l}\text { 1.2 Independence, } \\
\text { accountability and }\end{array}$ & $\begin{array}{l}\text { The Bl Act defines the supervisory objectives and provides for the operational } \\
\text { independence of Bl. Bl is accountable to the parliament. In addition to periodic }\end{array}$ \\
\hline
\end{tabular}




\begin{tabular}{|c|c|}
\hline Core Principle & Comments \\
\hline transparency & $\begin{array}{l}\text { visits to the House of Representatives, BI submits a quarterly report to that body } \\
\text { where explanations may be given on matters pertaining to supervision. Removal } \\
\text { procedures and the broad reasons for removal are contained in the BI Act and are } \\
\text { consistent with good practice. While the removal is disclosed, the reason for } \\
\text { removal is not disclosed. }\end{array}$ \\
\hline 1.3 Legal framework & $\begin{array}{l}\text { The } \mathrm{BI} \text { Act provides } \mathrm{BI} \text { with the authority to issue and withdraw banking licenses, } \\
\text { regulate and supervise the banking system, set prudential requirements, gather } \\
\text { periodic and ad hoc information from the industry, and conduct examinations to } \\
\text { verify the adequacy and veracity of the information submitted. BI consults with the } \\
\text { industry over all major regulatory initiatives. }\end{array}$ \\
\hline 1.4 Legal powers & $\begin{array}{l}\text { The BI Act contains sufficient powers for BI to ensure compliance with prudential } \\
\text { standards and regulations, laws, and guidelines. BI has full powers to enforce } \\
\text { compliance and has a range of powers sufficient to address any given situation up } \\
\text { to and including revocation of the license. }\end{array}$ \\
\hline 1.5 Legal protection & $\begin{array}{l}\text { The BI Act contains provisions under Article } 45 \text { that protect supervisory staff from } \\
\text { legal prosecution for any actions or decisions made in 'good faith' when performing } \\
\text { their supervisory duties. The law does not explicitly state presumption of good faith } \\
\text { in favor of supervisory staff and consequently the existing provisions cast a heavy } \\
\text { burden of proof on them, which together does not provide effective protection. } \\
\text { Legal provisions/ regulations provide neither adequate protection to supervisory } \\
\text { staff against omissions nor costs for defending their actions. Protection to BI as the } \\
\text { supervisory authority is absent. }\end{array}$ \\
\hline 1.6 Cooperation & $\begin{array}{l}\mathrm{BI} \text { and LPS have signed a formal MOU, which covers regular information sharing } \\
\text { in respect of all banks. These cooperative efforts are also encased in a BI } \\
\text { regulation and the LPS Act. There is no formal MOU or regulation with regard to } \\
\text { information sharing between } \mathrm{BI} \text { and Bapepam-LK or the MOF; this is also the case } \\
\text { with the foreign supervisors. }\end{array}$ \\
\hline 2. Permissible activities & $\begin{array}{l}\text { The Banking Act clearly defines the term 'banking', all permitted banking activities, } \\
\text { and impermissible activities. Deposit taking in cooperatives and micro finance } \\
\text { institutions is governed by appropriate laws. Law and practice combine to ensure } \\
\text { that the term bank is used only by those licensed by Bl. }\end{array}$ \\
\hline 3. Licensing criteria & $\begin{array}{l}\text { BI, as the licensing authority, has the authority to set criteria for licensing, to reject } \\
\text { applications that do not meet the set standards, and to revoke a license if it was } \\
\text { issued on the basis of false information. The criteria for issuing a license are similar } \\
\text { to those used in ongoing supervision. As there have been no applications for } \\
\text { opening a new bank in Indonesia since 1999, the effectiveness of the licensing } \\
\text { process could not be assessed. }\end{array}$ \\
\hline $\begin{array}{l}\text { 4. Transfer of significant } \\
\text { ownership }\end{array}$ & $\begin{array}{l}\text { BI defines significant ownership as equal to or exceeding } 25 \text { percent and includes } \\
\text { parties acting in concert or otherwise connected. While the transfer of shares } \\
\text { resulting in ownership exceeding } 25 \text { percent requires Bl's prior approval, any } \\
\text { transfer of ownership above } 5 \text { percent and up to } 25 \text { percent must be reported to BI } \\
\text { within } 10 \text { days. BI has the authority to enforce divestiture or reject any proposals } \\
\text { that hinder appropriate supervision. BI has adequate authority to take appropriate } \\
\text { action to modify, reverse or otherwise address a change of control that has taken } \\
\text { place without the necessary notification to or approval from the supervisor. }\end{array}$ \\
\hline 5. Major acquisitions & $\begin{array}{l}\text { BI regulations prohibit banks' equity participation in a company in the non-financial } \\
\text { sector and require Bl's prior approval for any form of equity participation in the } \\
\text { financial sector. BI regulations apply at a solo bank level and prescribe a cap on } \\
\text { bank's aggregate 'equity participation' at } 25 \text { percent of the bank's capital. BI is } \\
\text { empowered to enforce divestment of any existing equity participation, or reject any } \\
\text { equity participation proposal made by banks, if the participation will impede the } \\
\text { supervisory process. There is a gap in regulations as these do not apply to equity } \\
\text { investments through the debt resolution route and those undertaken by the banks' } \\
\text { subsidiaries/ group entities. }\end{array}$ \\
\hline
\end{tabular}




\begin{tabular}{|c|c|}
\hline Core Principle & Comments \\
\hline 6. Capital adequacy & $\begin{array}{l}\text { Banks in Indonesia are required to maintain minimum capital on the lines of Basel I } \\
\text { methodology requiring at least } 8 \text { percent of total risk weighted assets, both at solo } \\
\text { and consolidated levels. Market risk capital charge is applicable only to certain } \\
\text { banks that meet specified criteria relating to the bank's trading book size or total } \\
\text { assets, and covers } 95 \text { percent of banking system assets and } 99 \text { percent of trading } \\
\text { book assets. The capital adequacy norms are inconsistent with Basel principles } \\
\text { with regard to definition of capital and dilution of risk weights and warrant } \\
\text { immediate strengthening. Full implementation of Basel II is expected from January } \\
2014 \text {. }\end{array}$ \\
\hline $\begin{array}{l}\text { 7. Risk management } \\
\text { process }\end{array}$ & $\begin{array}{l}\text { BI regulations on the risk management process in banks require non-complex } \\
\text { banks to establish risk management policies and procedures for at least credit risk, } \\
\text { market risk, operational risk, and liquidity risk, while complex banking } \\
\text { organizations, must additionally consider other material risks, including legal, } \\
\text { reputational, strategic, and compliance risks. Regulations require adequate board } \\
\text { and senior management level involvement. Banks are required to perform quarterly } \\
\text { risk profile self-assessments of their solo and consolidated positions and provide } \\
\text { them to BI. Banks in Indonesia largely lack internal methodologies for assessing } \\
\text { their overall capital adequacy in relation to their risk profile and there is inadequate } \\
\text { capacity and focus on the validation of internal models. Recent events suggest that } \\
\text { the Indonesian banking system is not fully equipped to manage its risk exposures } \\
\text { effectively, particularly during adverse situations, and that supervisory capacity } \\
\text { needs to be enhanced. }\end{array}$ \\
\hline 8. Credit risk & $\begin{array}{l}\text { BI regulations require banks to effectively manage risks arising from their credit } \\
\text { and investment activities, including establishing policies and developing } \\
\text { procedures to identify, measure, monitor, and control credit risk. Regulations also } \\
\text { emphasize the importance of Board involvement in the process. While the } \\
\text { framework for credit risk management in Indonesian banks is broadly in } \\
\text { compliance with the requirements under this principle, there are gaps in aspects } \\
\text { such as large exposures, related party exposures, asset classification and } \\
\text { provisioning requirements, and country risk. }\end{array}$ \\
\hline $\begin{array}{l}\text { 9. Problem assets, } \\
\text { provisions, and reserves }\end{array}$ & $\begin{array}{l}\text { BI regulations require banks to establish minimum standards for the identification } \\
\text { and classification of problem assets, the establishment of general and specific loan } \\
\text { loss provisions, loan write-offs, and debt restructuring. The asset classification and } \\
\text { provisioning norms applied for non performing loans show several weaknesses, } \\
\text { which collectively could lead to understatement of NPLs, under provisioning, and } \\
\text { overstatement of income with implications for capital adequacy; these need to be } \\
\text { fixed immediately. There is a requirement that NPLs be reported to banks' Boards, } \\
\text { but there is no evidence that BoCs are actively managing the problem assets } \\
\text { portfolio. }\end{array}$ \\
\hline 10. Large exposure limits & $\begin{array}{l}\text { BI regulations (on legal lending limits - (LLL)) prescribe the ground rules for } \\
\text { identifying a borrower group, and supervisors have sufficient discretion to exercise } \\
\text { judgment in determining groups of connected counterparties. BI regulations need } \\
\text { to address shortcomings in the definition of exposure, and promote the concept of } \\
\text { 'large exposures' and 'portfolio concentrations', with appropriate prudential limits, } \\
\text { and reduce the time presently allowed for rectifying breaches. Further, from the } \\
\text { perspective of risk concentration, it would be relevant for BI to consider (a) gross } \\
\text { exposures without any deductions, and (b) SOEs as a group. }\end{array}$ \\
\hline $\begin{array}{l}\text { 11. Exposure to related } \\
\text { parties }\end{array}$ & $\begin{array}{l}\text { The definition and limits applicable to related parties are stipulated in BI regulations } \\
\text { and are applied both at solo and consolidated levels. BI regulations stipulate that } \\
\text { the processes, criteria, and controls for assuming exposures on related parties and } \\
\text { the terms of sanctions must be at least as stringent as the procedures/underwriting } \\
\text { standards for non related counterparties, and requires that any related party } \\
\text { exposure is assumed only with prior approval from the Board of Commissioners } \\
\text { (BoC). Regulations allow exemptions from the definition of 'related party' and }\end{array}$ \\
\hline
\end{tabular}




\begin{tabular}{|c|c|}
\hline Core Principle & Comments \\
\hline & $\begin{array}{l}\text { 'exposures', and do not address non-credit transactions with related parties; this } \\
\text { results in some gaps, and hence the regulations do not fully address conflicts of } \\
\text { interest. Regulations do not explicitly require the exclusion of interested persons } \\
\text { from the process of granting, managing, and resolving related party exposures, and } \\
\text { do not cover handling of NPLs in related party transactions. }\end{array}$ \\
\hline $\begin{array}{l}\text { 12. Country and transfer } \\
\text { risks }\end{array}$ & $\begin{array}{l}\text { BI regulations do not address country and transfer risk. The supervisory process } \\
\text { does not devote adequate resources to this element during either the off-site or on- } \\
\text { site processes. As a result, this risk is largely absent from the supervisory radar. BI } \\
\text { must address this regulatory gap and enhance supervisory capacity. }\end{array}$ \\
\hline 13. Market risks & $\begin{array}{l}\text { BI regulations on the risk management framework, among others, address market } \\
\text { risk management and require banks to manage risks in an effective manner that } \\
\text { encompasses active supervision by the Board of Commissioners (BoC) and the } \\
\text { Board of Directors (BoD). The guidelines address interest rate risk and foreign } \\
\text { exchange risk under market risk for solo banks and include equity risk and } \\
\text { commodities risk for consolidated banks. Only banks above a certain threshold are } \\
\text { required to maintain capital for market risks. Stress testing outcomes are not } \\
\text { explicitly required to feed into banks' risk management policies and practices, } \\
\text { including contingency planning. }\end{array}$ \\
\hline 14. Liquidity risk & $\begin{array}{l}\text { BI regulations require banks to manage liquidity risk in a manner that is } \\
\text { commensurate with the bank's size and complexity, on a solo and consolidated } \\
\text { basis. BI has issued revised guidelines on liquidity risk management that become } \\
\text { operational on October } 30,2009 \text {, to better align Bl's regulatory expectations with } \\
\text { the Principles for Sound Liquidity Risk Management and Supervision } \\
\text { recommended by BCBS in September } 2008 \text {. BI regulations have some } \\
\text { shortcomings with regard to standards or benchmarks for slotting the various items } \\
\text { of assets and liabilities, making aggregation and inter-bank comparison difficult. } \\
\text { Banks are not explicitly required to manage liquidity currency-wise, or to inform the } \\
\text { BI when their contingency funding plans (CFPs) are triggered or when they are } \\
\text { facing liquidity problems. }\end{array}$ \\
\hline 15. Operational risk & $\begin{array}{l}\text { BI regulations define operational risk, but do not include legal risk, which is } \\
\text { addressed separately for selected banks, and require banks to develop an } \\
\text { operational risk management framework that is commensurate with their size and } \\
\text { complexity, on a solo and consolidated basis. BI regulations do not explicitly } \\
\text { capture the following elements related to operational risk, viz. outsourcing of risk, } \\
\text { business continuity planning in areas other than IT, legal risk in banks below a } \\
\text { certain threshold, and supervisory reporting of significant operational risk events. }\end{array}$ \\
\hline $\begin{array}{l}\text { 16. Interest rate risk in } \\
\text { the banking book }\end{array}$ & $\begin{array}{l}\text { BI regulations on risk management in banks do not explicitly cover interest rate risk } \\
\text { in the banking book (IRRBB); banks do not actively manage this risk and the } \\
\text { supervisors do not adequately focus on this risk. BI must address this regulatory } \\
\text { gap and enhance supervisory capacity. }\end{array}$ \\
\hline $\begin{array}{l}17 . \text { Internal control and } \\
\text { audit }\end{array}$ & $\begin{array}{l}\mathrm{BI} \text { regulations require the } \mathrm{BoC} \text { and the } \mathrm{BoD} \text { to ensure the creation, maintenance, } \\
\text { and oversight of an effective internal control mechanism that aims at safeguarding } \\
\text { and securing the property and assets of the bank; ensuring greater accuracy in } \\
\text { reporting; strengthening legal and regulatory compliance; minimizing financial } \\
\text { irregularities and fraud; and improving efficiency. Further, banks are required to } \\
\text { designate a compliance director and establish an independent internal audit unit. BI } \\
\text { regulations do not explicitly require a risk based audit framework in banks. BI does } \\
\text { not assess the internal control function as a separate function, in its entirety. } \\
\text { Banks' internal control functions lack the capacity as well as methodologies for } \\
\text { validating internal models and stress testing. }\end{array}$ \\
\hline $\begin{array}{l}\text { 18. Abuse of financial } \\
\text { services }\end{array}$ & $\begin{array}{l}\text { BI regulations detail the responsibilities and powers of the banking supervisor. } \\
\text { Banks are required to file regular compliance reports and BI examiners verify } \\
\text { compliance. At least annually, supervisors conduct an assessment of the }\end{array}$ \\
\hline
\end{tabular}




\begin{tabular}{|c|c|}
\hline Core Principle & Comments \\
\hline & $\begin{array}{l}\text { implementation of KYC and anti-money laundering controls including management } \\
\text { oversight, policies, practices and procedures, internal controls and audit MIS } \\
\text { systems, and training. The APG } 2008 \text { mutual evaluation has revealed several gaps } \\
\text { that can expose the banking system either directly or indirectly to abuse. BI has } \\
\text { addressed a few of these gaps through revised regulations. }\end{array}$ \\
\hline $\begin{array}{l}\text { 19. Supervisory } \\
\text { approach }\end{array}$ & $\begin{array}{l}\text { BI has in place a system designed to produce risk focused supervision. } \\
\text { Supervisory exercises are carried out in accordance with the risk profile. At least } \\
\text { once a year, banks are subject to an on-site inspection. Other on-site supervisory } \\
\text { exercises are carried out during the year depending on an individual bank's risk } \\
\text { assessment. While supervisors seem to have a good understanding of individual } \\
\text { banks and banking groups, the absence of a formal and encompassing review of } \\
\text { banking system trends might lead to a failure to detect an emerging problem. The } \\
\text { existing risk based framework would benefit from a sharper focus on consolidated } \\
\text { supervision methods, techniques, and procedures, and information sharing } \\
\text { agreements with Bapepam-LK and the Ministry of Finance. }\end{array}$ \\
\hline $\begin{array}{l}\text { 20. Supervisory } \\
\text { techniques }\end{array}$ & $\begin{array}{l}\text { Bl employs a satisfactory combination of on-site and off-site surveillance combined } \\
\text { with frequent communication with the banks they monitor. Weaknesses in banking } \\
\text { institutions are identified and pursued. The absence of formal information sharing } \\
\text { arrangements with other financial sector supervisory authorities adversely affects } \\
\text { the effectiveness of the bank supervision program. The absence of effective legal } \\
\text { protection dampens supervisors' willingness to make decisions and deviate from } \\
\text { accepted methods listed in the manual. }\end{array}$ \\
\hline 21. Supervisory reporting & $\begin{array}{l}\text { The BI Act requires all banks to submit detailed information covering the range of } \\
\text { prudential risks. Where pertinent, such information applies to the bank, } \\
\text { subsidiaries, and related or affiliated counterparties. Banks file returns on a solo } \\
\text { and consolidated basis. The off-site reports are subjected to verification during on- } \\
\text { site examinations. The off-site reports are not fully utilized to generate efficient and } \\
\text { useful peer group analysis. }\end{array}$ \\
\hline $\begin{array}{l}\text { 22. Accounting and } \\
\text { disclosure }\end{array}$ & $\begin{array}{l}\text { While BI requirements on accounting, auditing, valuation, maintenance of accounts } \\
\text { and public disclosure of financial statements are broadly in line with requirements, } \\
\text { weaknesses in accounting and auditing frameworks raise serious concerns, with } \\
\text { implications for the quality of financial statements and disclosures. While bank } \\
\text { disclosure requirements are broadly in consonance with this principle, there is } \\
\text { scope for improvement to promote the availability and comparability of banks' } \\
\text { audited financial condition. There is also value in increasing the scope of BI } \\
\text { disclosures. The introduction of new accounting standards is likely to pose some } \\
\text { challenges to the banking system and the supervisor, and needs close monitoring } \\
\text { by Bl. }\end{array}$ \\
\hline $\begin{array}{l}\text { 23. Corrective and } \\
\text { remedial powers of } \\
\text { supervisors }\end{array}$ & $\begin{array}{l}\text { There is clear evidence of the active monitoring of each commercial bank. } \\
\text { Supervisors are not hesitant to raise issues with the bank and demand corrective } \\
\text { action where appropriate. Regular progress reports on addressing deficiencies are } \\
\text { required. Supervisors have a large arsenal of powers, but it was not always } \\
\text { apparent that proper moderation or escalation was in use. Supervisory actions } \\
\text { range from administrative sanctions to removal of management and revocation of } \\
\text { licenses. The existing prompt corrective action is largely discretionary and BI tends } \\
\text { to allow banks to remain under intensive supervision for several years without } \\
\text { resolving the underlying weaknesses. }\end{array}$ \\
\hline $\begin{array}{l}\text { 24. Consolidated } \\
\text { supervision }\end{array}$ & $\begin{array}{l}\text { BI performs its oversight through dedicated teams for each commercial bank. } \\
\text { Regulatory reports are filed on a solo and consolidated basis, allowing for a deeper } \\
\text { understanding of where the organization is taking risk. On-site examinations } \\
\text { include, where necessary and prudent, examinations of risk taking in the } \\
\text { subsidiaries. Consolidated supervision is being accomplished largely by BI taking } \\
\text { responsibility for on-site supervision of the consolidated organization to cover for } \\
\text { other financial regulators where routine robust examinations are not a part of the }\end{array}$ \\
\hline
\end{tabular}




\begin{tabular}{|c|c|}
\hline Core Principle & Comments \\
\hline & $\begin{array}{l}\text { supervisory process. Lack of formal arrangements to transfer information between } \\
\text { domestic supervisors, combined with weaknesses in supervision of overseas } \\
\text { branches, can be a serious impediment to consolidated supervision. Present } \\
\text { exclusions allowed in the scope of consolidated supervision, non- application of } \\
\text { regulations on equity participation and sale of structured products at the } \\
\text { consolidated bank level, and lack of focus on intra-group transactions where the } \\
\text { bank is not directly involved, can expose the financial system to risks that are not } \\
\text { presently being monitored adequately. BI pays close attention to branches of } \\
\text { Indonesian banks located in the region. Frequent on-site visits and exchanges of } \\
\text { views with the host supervisor are routine. There is room for improvement, } \\
\text { however, in the supervision of other foreign branches like New York, London, and } \\
\text { Cayman Islands. Both formal and informal arrangements for ongoing information } \\
\text { sharing and coordination with the other supervisors (domestic and foreign) need to } \\
\text { be strengthened. }\end{array}$ \\
\hline $\begin{array}{l}25 \text {. Home-host } \\
\text { relationships }\end{array}$ & $\begin{array}{l}\text { BI maintains relationships with home and host supervisors on an ad-hoc basis. } \\
\text { While BI is making efforts to strengthen home-host relationships and one can } \\
\text { expect continued improvements, effective supervision of foreign banks requires the } \\
\text { continuous monitoring of the parent institution and includes reasonably frequent } \\
\text { communication with the home supervisors. BI lacks a uniform policy with respect to } \\
\text { aligning supervisory requirements with risks. BI has arrangements for the } \\
\text { exchange of information with close-by neighboring supervisors, but the lines of } \\
\text { communication for information exchange are less clear with the home supervisors } \\
\text { of systemically relevant foreign financial institutions. This also reflects the larger } \\
\text { issue of a non-cooperative attitude by some of the home supervisors. Information } \\
\text { exchanges that take place during routine examinations are usually at low levels } \\
\text { and without a structured agenda. For legal reasons, many jurisdictions can provide } \\
\text { supervisory information to a host country only if a formal information exchange } \\
\text { agreement is in place. This could place Bl at a significant disadvantage. BI must } \\
\text { identify systemically important foreign institutions, make a determination as to } \\
\text { whether the home country supervisor is competent and has the authority to enter } \\
\text { into information sharing agreements, and ensure a regular program of visits to the } \\
\text { home supervisors. }\end{array}$ \\
\hline
\end{tabular}

\section{Table 2. Summary Compliance with the Basel Core Principles-Detailed Assessments}

\begin{tabular}{|c|c|c|}
\hline Core Principle & Grading & Comments \\
\hline $\begin{array}{l}\text { 1. Objectives, } \\
\text { independence, powers, } \\
\text { transparency, and } \\
\text { cooperation }\end{array}$ & & \\
\hline $\begin{array}{l}\text { 1.1 Responsibilities and } \\
\text { objectives }\end{array}$ & C & $\begin{array}{l}\text { Laws and regulations clearly spell out Bl's responsibilities with } \\
\text { respect to licensing, prudential standards and requirements, } \\
\text { supervision of banks, and sanctioning powers. Regulations and } \\
\text { prudential standards are generally comprehensive and broadly meet } \\
\text { minimum requirements. }\end{array}$ \\
\hline $\begin{array}{l}1.2 \text { Independence, } \\
\text { accountability and } \\
\text { transparency }\end{array}$ & $\mathrm{C}$ & $\begin{array}{l}\text { The } \mathrm{BI} \text { Act defines the supervisory objectives and provides for the } \\
\text { operational independence of the } \mathrm{BI} \text {. } \mathrm{BI} \text { is accountable to the } \\
\text { parliament. Removal procedures are contained in the } \mathrm{BI} \text { Act and are } \\
\text { consistent with good practice. While the removal is disclosed, the } \\
\text { reason for removal is not disclosed. }\end{array}$ \\
\hline
\end{tabular}




\begin{tabular}{|c|c|c|}
\hline Core Principle & Grading & Comments \\
\hline 1.3 Legal framework & C & $\begin{array}{l}\text { The } \mathrm{BI} \text { Act provides } \mathrm{BI} \text { with adequate authority to regulate and } \\
\text { supervise the banking system. }\end{array}$ \\
\hline 1.4 Legal powers & $\mathrm{C}$ & $\begin{array}{l}\text { The BI Act contains sufficient powers for } \mathrm{BI} \text { to ensure compliance with } \\
\text { prudential standards and regulations, laws, and guidelines. BI has full } \\
\text { powers to enforce compliance and has a range of powers sufficient to } \\
\text { address any given situation up to and including revocation of the } \\
\text { license. }\end{array}$ \\
\hline 1.5 Legal protection & MNC & $\begin{array}{l}\text { The BI Act contains provisions under Article } 45 \text { that protect } \\
\text { supervisory staff from legal prosecution for any actions or decisions } \\
\text { made in 'good faith' when performing their supervisory duties. The } \\
\text { law does not explicitly state presumption of good faith in favor of } \\
\text { supervisory staff and consequently the existing provisions cast a } \\
\text { heavy burden of proof on them, which together do not provide } \\
\text { effective protection. Legal provisions/ regulations provide neither } \\
\text { adequate protection to supervisory staff against omissions nor costs } \\
\text { for defending their actions. Protection to BI as the supervisory } \\
\text { authority is absent. }\end{array}$ \\
\hline 1.6 Cooperation & MNC & $\begin{array}{l}\mathrm{BI} \text { and LPS have signed a formal MOU which covers regular } \\
\text { information sharing in respect of all banks. These cooperative efforts } \\
\text { are also encased in a BI regulation and the LPS Act. There is no } \\
\text { formal MOU or regulation with regard to information sharing between } \\
\mathrm{BI} \text { and Bapepam-LK or the MOF; this is also the case with the foreign } \\
\text { supervisors. }\end{array}$ \\
\hline 2. Permissible activities & $\mathrm{C}$ & $\begin{array}{l}\text { The Banking Act clearly defines the term 'banking,' all other permitted } \\
\text { banking activities, and impermissible activities. Law and practice } \\
\text { combine to ensure that the term 'bank' is used only by those licensed } \\
\text { by the Bl. Deposit taking in cooperatives and micro finance } \\
\text { institutions is governed by appropriate laws. }\end{array}$ \\
\hline 3. Licensing criteria & LC & $\begin{array}{l}\mathrm{BI} \text {, as the licensing authority, has the authority to set criteria for } \\
\text { licensing, to reject applications that do not meet the set standards and } \\
\text { to revoke a license, if it was issued on the basis of false information. } \\
\text { The criteria for issuing a license are similar to those used in ongoing } \\
\text { supervision. As there have been no applications for opening a new } \\
\text { bank in Indonesia since } 1999 \text {, the effectiveness of the licensing } \\
\text { process could not be assessed. }\end{array}$ \\
\hline $\begin{array}{l}\text { 4. Transfer of significant } \\
\text { ownership }\end{array}$ & $\mathrm{C}$ & $\begin{array}{l}\text { BI clearly defines the threshold for significant ownership at } 25 \text { percent } \\
\text { and includes parties acting in concert or otherwise connected, } \\
\text { requiring its approval. While the transfer of shares resulting in } \\
\text { ownership exceeding } 25 \text { percent requires Bl's prior approval, transfer } \\
\text { of shares resulting in ownership above } 5 \text { percent and up to } 25 \text { percent } \\
\text { must be reported to } \mathrm{BI} \text { within } 10 \text { days. BI has the authority to (i) } \\
\text { enforce divestiture or reject any proposals that hinder appropriate } \\
\text { supervision, and (ii) take appropriate action to modify, reverse or } \\
\text { otherwise address a change of control that has taken place without } \\
\text { the necessary notification to or approval from the supervisor. The BI } \\
\text { may consider reducing the threshold of } 25 \text { percent for obtaining prior } \\
\text { approval of transfers or consider applying the same level of detailed } \\
\text { scrutiny to all transfers of } 5 \text { percent or more. }\end{array}$ \\
\hline 5. Major acquisitions & LC & $\begin{array}{l}\text { BI regulations and supervision prohibit banks' equity participation in } \\
\text { the non-financial sector and require BI's prior approval for equity } \\
\text { participation in the financial sector. BI is empowered to enforce } \\
\text { divestment, or reject any proposal, if the participation will hinder the }\end{array}$ \\
\hline
\end{tabular}




\begin{tabular}{|c|c|c|}
\hline Core Principle & Grading & Comments \\
\hline & & $\begin{array}{l}\text { supervisory process. These regulations do not apply to equity } \\
\text { investments through the debt resolution route and those undertaken } \\
\text { by the banks' subsidiaries/ group entities. }\end{array}$ \\
\hline 6. Capital adequacy & $\mathrm{LC}$ & $\begin{array}{l}\text { Banks are required to maintain minimum capital on the lines of Basel I } \\
\text { methodology requiring at least } 8 \text { percent of total risk weighted assets, } \\
\text { both at solo and consolidated levels. The market risk capital charge is } \\
\text { applicable only to certain banks that meet specified criteria, and } \\
\text { covers } 95 \text { percent of banking system assets and } 99 \text { percent of trading } \\
\text { book assets. The capital adequacy norms are inconsistent with Basel } \\
\text { principles with regard to definition of capital and dilution of risk } \\
\text { weights and warrant immediate strengthening. BI plans to implement } \\
\text { Basel II for all commercial banks by adopting the simple approaches } \\
\text { in stages, reaching full implementation in } 2014 \text {. }\end{array}$ \\
\hline $\begin{array}{l}\text { 7. Risk management } \\
\text { process }\end{array}$ & $\mathrm{LC}$ & $\begin{array}{l}\text { Non-complex banks are required to establish risk management } \\
\text { policies and procedures for at least credit risk, market risk, } \\
\text { operational risk, and liquidity risk, while complex banks must } \\
\text { additionally consider legal, reputational, strategic, and compliance } \\
\text { risks. Regulations require adequate board and senior management } \\
\text { level involvement. Banks in Indonesia largely lack internal } \\
\text { methodologies for assessing their overall capital adequacy in relation } \\
\text { to their risk profile and there is inadequate capacity and focus on } \\
\text { validation of internal models. Recent events suggest that the } \\
\text { Indonesian banking system is not fully equipped to manage its risk } \\
\text { exposures effectively, particularly during adverse situations. These } \\
\text { events also indicate the need to enhance supervisory capacity in this } \\
\text { area. }\end{array}$ \\
\hline 8. Credit risk & LC & $\begin{array}{l}\text { BI regulations require banks to effectively manage risks arising from } \\
\text { their credit and investment activities, and also emphasize the } \\
\text { importance of Board involvement in the process. There are gaps in } \\
\text { certain credit risk aspects such as large exposures, related party } \\
\text { exposures, asset classification and provisioning requirements, and } \\
\text { country risk. }\end{array}$ \\
\hline $\begin{array}{l}\text { 9. Problem assets, } \\
\text { provisions, and } \\
\text { reserves }\end{array}$ & MNC & $\begin{array}{l}\text { BI regulations require banks to establish minimum standards for the } \\
\text { identification and classification of problem assets, the establishment } \\
\text { of general and specific loan loss provisions, loan write-offs, and debt } \\
\text { restructuring. The norms applied for non performing loans show } \\
\text { several weaknesses, which collectively lead to the understatement of } \\
\text { NPLs, under provisioning, and overstatement of income with } \\
\text { implications for capital adequacy. There is a requirement that NPLs } \\
\text { be reported to banks' Boards, but there is no evidence that BoCs are } \\
\text { actively managing the problem assets portfolio. }\end{array}$ \\
\hline $\begin{array}{l}\text { 10. Large exposure } \\
\text { limits }\end{array}$ & $\mathrm{LC}$ & $\begin{array}{l}\text { BI regulations prescribe the ground rules for identifying a borrower } \\
\text { group and supervisors have sufficient discretion to exercise judgment } \\
\text { in determining groups of connected counterparties. BI needs to } \\
\text { address shortcomings in the definition of exposure, promote the } \\
\text { concept of 'large exposures' and 'portfolio concentrations', with } \\
\text { appropriate prudential limits, and reduce the time allowed to rectify } \\
\text { breaches of current limits. Further, from the perspective of risk } \\
\text { concentration, it would be relevant for BI to consider (a) gross } \\
\text { exposures without any deductions, and (b) SOEs as a group. }\end{array}$ \\
\hline $\begin{array}{l}\text { 11. Exposure to related } \\
\text { parties }\end{array}$ & LC & $\begin{array}{l}\text { The definition and limits applicable to related parties are stipulated in } \\
\text { BI regulations and are applied both at solo and consolidated levels. } \\
\text { Exemptions allowed by the regulations result in gaps, and conflicts of }\end{array}$ \\
\hline
\end{tabular}




\begin{tabular}{|c|c|c|}
\hline Core Principle & Grading & Comments \\
\hline & & interest are not fully addressed. \\
\hline $\begin{array}{l}\text { 12. Country and } \\
\text { transfer risks }\end{array}$ & $\mathrm{NC}$ & $\begin{array}{l}\text { BI regulations do not address country and transfer risk. The } \\
\text { supervisory process does not devote adequate resources to this } \\
\text { element during either the off-site or on-site processes. As a result, } \\
\text { this risk is largely unaddressed in the banking system. }\end{array}$ \\
\hline 13. Market risks & LC & $\begin{array}{l}\text { BI regulations on the risk management framework address market } \\
\text { risk management and require banks to manage risks in an effective } \\
\text { manner that encompasses active supervision by the BoC and the } \\
\text { BoD. The guidelines address interest rate risk and foreign exchange } \\
\text { risk under market risk for solo banks and also include equity risk and } \\
\text { commodities risk for consolidated banks. Stress testing outcomes are } \\
\text { not explicitly required to feed into banks' risk management policies } \\
\text { and practices, including contingency planning. }\end{array}$ \\
\hline 14. Liquidity risk & LC & $\begin{array}{l}\text { BI regulations require banks to manage liquidity risk in a manner that } \\
\text { is commensurate with their size and complexity, on a solo and } \\
\text { consolidated basis. BI regulations fall short on standards or } \\
\text { benchmarks for slotting the various items of assets and liabilities, } \\
\text { making aggregation and inter-bank comparison difficult. Banks are } \\
\text { not explicitly required to manage liquidity currency-wise, or to inform } \\
\text { the BI when their contingency funding plans (CFPs) are triggered or } \\
\text { when they are facing liquidity problems. }\end{array}$ \\
\hline 15. Operational risk & $\mathrm{LC}$ & $\begin{array}{l}\text { BI regulations define operational risk, but do not include legal risk, } \\
\text { which is addressed separately for selected banks, and require banks } \\
\text { to develop an operational risk management framework that is } \\
\text { commensurate with their size and complexity on a solo and } \\
\text { consolidated basis. BI regulations do not explicitly capture the } \\
\text { following elements related to operational risk: outsourcing risk, } \\
\text { business continuity planning in areas other than IT, legal risk in banks } \\
\text { below a certain threshold, and supervisory reporting of significant } \\
\text { operational risk events. }\end{array}$ \\
\hline $\begin{array}{l}\text { 16. Interest rate risk in } \\
\text { the banking book }\end{array}$ & $\mathrm{NC}$ & $\begin{array}{l}\text { BI regulations on risk management in banks do not explicitly cover } \\
\text { interest rate risk in the banking book (IRRBB); banks do not actively } \\
\text { manage this risk and the supervisors do not adequately focus on this } \\
\text { risk. }\end{array}$ \\
\hline $\begin{array}{l}\text { 17. Internal control and } \\
\text { audit }\end{array}$ & LC & $\begin{array}{l}\text { BI regulations require the BoC and the BoD to ensure the creation, } \\
\text { maintenance, and oversight of an effective internal control } \\
\text { mechanism. Banks are required to designate a compliance director } \\
\text { and establish an independent internal audit unit. Shortcomings } \\
\text { include (a) the internal audit is not risk-based; (b) the internal control } \\
\text { function is not assessed independently; and (c) banks lack the } \\
\text { capacity as well as methodologies for validating internal models and } \\
\text { stress testing. }\end{array}$ \\
\hline $\begin{array}{l}\text { 18. Abuse of financial } \\
\text { services }\end{array}$ & LC & $\begin{array}{l}\text { BI regulations detail the responsibilities and powers of the banking } \\
\text { supervisor. Banks are required to file regular compliance reports and } \\
\text { BI examiners verify compliance. At least annually, supervisors } \\
\text { conduct an assessment of the implementation of KYC and anti-money } \\
\text { laundering controls including management oversight, policies, } \\
\text { practices and procedures, internal controls and audit MIS systems, } \\
\text { and training. The APG } 2008 \text { mutual evaluation has revealed several } \\
\text { gaps that can expose the banking system either directly or indirectly } \\
\text { to abuse. BI has addressed a few gaps identified by the APG } 2008 \\
\text { mutual evaluation through revised regulations. }\end{array}$ \\
\hline
\end{tabular}




\begin{tabular}{|c|c|c|}
\hline Core Principle & Grading & Comments \\
\hline $\begin{array}{l}\text { 19. Supervisory } \\
\text { approach }\end{array}$ & LC & $\begin{array}{l}\text { BI has in place a system designed to produce risk focused } \\
\text { supervision. Supervisory exercises are carried out in accordance with } \\
\text { the risk profile. At least once a year banks are subject to an on-site } \\
\text { inspection. The absence of a formal and encompassing review of } \\
\text { banking system trends might lead to a failure to detect an emerging } \\
\text { problem. The existing risk based framework would benefit from a } \\
\text { sharper focus on consolidated supervision. }\end{array}$ \\
\hline $\begin{array}{l}\text { 20. Supervisory } \\
\text { techniques }\end{array}$ & $\mathrm{LC}$ & $\begin{array}{l}\text { Bl employs a reasonable combination of on-site and off-site } \\
\text { surveillance along with frequent communication with the banks they } \\
\text { monitor. The absence of formal information sharing arrangements } \\
\text { with other financial sector supervisory authorities adversely affects } \\
\text { the effectiveness of the bank supervision program. The absence of } \\
\text { effective legal protection dampens supervisors' willingness to make } \\
\text { decisions and deviate from accepted methods listed in the manual. }\end{array}$ \\
\hline $\begin{array}{l}\text { 21. Supervisory } \\
\text { reporting }\end{array}$ & $\mathrm{LC}$ & $\begin{array}{l}\text { The BI Act requires all banks to submit detailed information covering } \\
\text { the full and complete range of prudential risks on a solo and } \\
\text { consolidated basis. The off-site reports are subjected to verification } \\
\text { during on-site examinations. The off-site reports are not prepared on a } \\
\text { consolidated basis for all risks, and they are not fully utilized to } \\
\text { generate efficient and useful peer group analysis. }\end{array}$ \\
\hline $\begin{array}{l}\text { 22. Accounting and } \\
\text { disclosure }\end{array}$ & $\mathrm{LC}$ & $\begin{array}{l}\text { While BI requirements on accounting, auditing, valuation, } \\
\text { maintenance of accounts and public disclosure of financial statements } \\
\text { are broadly in line with requirements, weaknesses in accounting and } \\
\text { auditing frameworks raise serious concerns, with implications for the } \\
\text { quality of financial statements and disclosures. While bank disclosure } \\
\text { requirements are broadly in consonance with this principle, there is } \\
\text { scope for improvement to promote the availability and comparability } \\
\text { of banks' audited financial condition. There is also value in increasing } \\
\text { the scope of BI disclosures. The introduction of new accounting } \\
\text { standards is likely to pose some challenges to the banking system } \\
\text { and the supervisor, and needs close monitoring by BI. }\end{array}$ \\
\hline $\begin{array}{l}\text { 23. Corrective and } \\
\text { remedial powers of } \\
\text { supervisors }\end{array}$ & $\mathrm{LC}$ & $\begin{array}{l}\text { There is evidence of the active monitoring of each commercial bank. } \\
\text { Supervisors are not hesitant to raise issues with the bank and } \\
\text { demand corrective action where appropriate. Supervisors have a } \\
\text { large arsenal of powers, but it was not always apparent that } \\
\text { consistency, proper moderation or escalation was in use. The } \\
\text { existing prompt corrective action is largely discretionary and BI tends } \\
\text { to allow banks to remain under intensive supervision for several } \\
\text { years without resolving the underlying weaknesses. One efficient way } \\
\text { to promote a less discretionary approach and portray BI as a } \\
\text { responsive institution is to build certain objective and automatic } \\
\text { triggers into this framework. }\end{array}$ \\
\hline $\begin{array}{l}\text { 24. Consolidated } \\
\text { supervision }\end{array}$ & $\mathrm{LC}$ & $\begin{array}{l}\text { BI performs its oversight through dedicated teams for each } \\
\text { commercial bank. Regulatory reports are filed on a solo and } \\
\text { consolidated basis allowing for a deeper understanding of where the } \\
\text { organization is taking risk. On-site examinations include, where } \\
\text { necessary and prudent, examinations of risk taking in the } \\
\text { subsidiaries. Consolidated supervision is being accomplished largely } \\
\text { by Bl taking responsibility for on-site supervision of the consolidated } \\
\text { organization to cover for other financial regulators where routine } \\
\text { robust examinations are not a part of the supervisory process. Lack of } \\
\text { formal arrangements to transfer information between domestic } \\
\text { supervisors, combined with weaknesses in supervision of overseas }\end{array}$ \\
\hline
\end{tabular}




\begin{tabular}{|c|c|c|}
\hline Core Principle & Grading & Comments \\
\hline & & $\begin{array}{l}\text { branches, is a serious impediment to consolidated supervision. } \\
\text { Exclusions from the scope of consolidated supervision, non } \\
\text { application of regulations on equity participation and sale of structured } \\
\text { products at the consolidated bank level, and intra-group transactions } \\
\text { where the bank is not directly involved can expose the banks to risks } \\
\text { that are currently not under the supervisory radar. BI pays limited } \\
\text { attention to the oversight of foreign operations by the banks' } \\
\text { management. Both formal and informal arrangements for ongoing } \\
\text { information sharing and coordination with the other supervisors } \\
\text { (domestic and foreign) are largely absent. }\end{array}$ \\
\hline $\begin{array}{l}25 . \text { Home-host } \\
\text { relationships }\end{array}$ & MNC & $\begin{array}{l}\text { BI maintains relationships with home and host supervisors on an ad- } \\
\text { hoc basis. While BI is making efforts to strengthen home-host } \\
\text { relationships and one can expect continued improvements, effective } \\
\text { supervision of foreign banks requires continuous monitoring of the } \\
\text { parent institution and includes reasonably frequent communication } \\
\text { with the home supervisors. BI lacks a uniform policy with respect to } \\
\text { aligning supervisory requirements with risks. BI has arrangements for } \\
\text { the exchange of information with close-by neighboring supervisors, } \\
\text { but the lines of communication for information exchange are less } \\
\text { clear with the home supervisors of systemically relevant foreign } \\
\text { financial institutions. Non-compliance with the principle also reflects } \\
\text { the non-cooperative attitude of some of the home supervisors. } \\
\text { Information exchanges that take place during routine examinations } \\
\text { are usually at low levels and without a structured agenda. As many } \\
\text { jurisdictions can provide supervisory information to a host country } \\
\text { only if a formal information exchange agreement is in place, BI is at a } \\
\text { significant disadvantage. }\end{array}$ \\
\hline & & $\begin{array}{l}\text { mpliant (C) - 6, Largely compliant (LC) }-18 \\
\text { VC) }-4, \text { Noncompliant (NC) }-2, \text { Not applicable }(\mathrm{N} / \mathrm{A})-\text { nil }\end{array}$ \\
\hline
\end{tabular}

\section{Recommended action plan and authorities' response}

\section{Recommended plan of action}

38. On the basis of the above assessment, an action plan for achieving full compliance with each of the core principles has been recommended to the authorities. This is provided below.

\section{Table 3. Recommended Plan of Action to Improve Compliance with the Basel Core Principles}

\begin{tabular}{|l|l|}
\hline Core Principles & Comments \\
\hline 1.5 Legal protection & $\begin{array}{l}\text { Urgent amendments to the BI Act are required to explicitly state presumption of } \\
\text { good faith in favor of supervisory staff; to protect supervisory staff from omissions } \\
\text { and provide all costs for defending their actions; and to grant protection to BI as a } \\
\text { supervisory authority. }\end{array}$ \\
\hline 1.6 Cooperation & $\begin{array}{l}\text { Bl should put in place effective information exchange arrangements with other } \\
\text { domestic financial sector supervisors and foreign supervisors. }\end{array}$ \\
\hline
\end{tabular}




\begin{tabular}{|c|c|}
\hline Core Principles & Comments \\
\hline $\begin{array}{l}\text { 4. Transfer of } \\
\text { significant ownership }\end{array}$ & $\begin{array}{l}\text { Banks should be required to notify } \mathrm{Bl} \text { as soon as they become aware of any } \\
\text { material information that might affect the suitability of major shareholders, } \\
\text { including controlling shareholders. The } \mathrm{BI} \text { may consider reducing the threshold of } \\
25 \text { percent for obtaining prior approval of transfers or consider applying the same } \\
\text { level of detailed scrutiny to all transfers of } 5 \text { percent or more. }\end{array}$ \\
\hline 5. Major acquisitions & $\begin{array}{l}\text { As banks can be exposed to equity risks through temporary equity participation } \\
\text { and through group entities' equity investments, these need to be brought within } \\
\text { the purview of the BI regulations. The accounting norms for equity participation } \\
\text { need to be reviewed and brought in line with the intent to hold. }\end{array}$ \\
\hline 6. Capital adequacy & $\begin{array}{l}\text { BI should review its current regulations with respect to risk weights and Tier } 1 \\
\text { capital to ensure consistency with the Basel I framework. BI may consider } \\
\text { formally requiring systemically important banks and banking groups to maintain } \\
\text { capital above the minimum prescribed in the Basel framework. BI should also } \\
\text { consider encouraging banks to adopt a forward looking approach and factor } \\
\text { stress test outcomes into their capital planning framework. BI should require } \\
\text { banks to maintain capital adequacy in line with the Basel I norms until Pillar } 2 \text { and } \\
\text { Pillar } 3 \text { of the Basel II framework become effectively operational in } 2014 \text {. }\end{array}$ \\
\hline $\begin{array}{l}\text { 7. Risk management } \\
\text { process }\end{array}$ & $\begin{array}{l}\text { As the Indonesian banking system is moving to Basel II soon, internal } \\
\text { methodologies for assessing their overall capital adequacy and validation of } \\
\text { internal models gain greater importance. BI must issue appropriate regulations as } \\
\text { well as guidelines to banks on these aspects and on management of interest rate } \\
\text { risk in the banking book. BI must also improve its supervisory capacity with regard } \\
\text { to oversight of risk management systems in banks, particularly with regard to new } \\
\text { business lines and new products. }\end{array}$ \\
\hline 8. Credit risk & $\begin{array}{l}\text { BI should aim at removing all significant gaps in credit risk related aspects like } \\
\text { large exposures, related party exposures, asset classification and provisioning } \\
\text { requirements, and country risk. }\end{array}$ \\
\hline $\begin{array}{l}\text { 9. Problem assets, } \\
\text { provisions, and } \\
\text { reserves }\end{array}$ & $\begin{array}{l}\text { The asset classification and provisioning norms for NPLs should be reviewed and } \\
\text { revised to ensure that the banking system is adequately identifying and managing } \\
\text { problem assets, including provisioning, in line with newly emerging risks. Matrix } \\
\text { provisioning requires frequent review to make sure it is aligned with actual system } \\
\text { experience. Regulations may need to be enhanced to ensure the BoC is actively } \\
\text { managing problem assets. }\end{array}$ \\
\hline $\begin{array}{l}\text { 10. Large exposure } \\
\text { limits }\end{array}$ & $\begin{array}{l}\text { BI regulations need to address the shortcomings in the definition of exposure, } \\
\text { ensure adoption of the concept of large exposures and portfolio concentrations } \\
\text { including prescription of appropriate prudential limits, and reduce the time allowed } \\
\text { to banks to rectify breaches and comply with prudential limits. Further, from the } \\
\text { perspective of risk concentration, it would be relevant for BI to consider (a) gross } \\
\text { exposures without any deductions, and (b) SOEs as a group. It would also be } \\
\text { useful for the BI to review the concept of 'market developments' on account of } \\
\text { which banks may breach the limits, and make it more restrictive to ensure better } \\
\text { credit risk management discipline in banks. }\end{array}$ \\
\hline $\begin{array}{l}\text { 11. Exposure to related } \\
\text { parties }\end{array}$ & $\begin{array}{l}\text { Regulations need to be reviewed to fully address conflict of interest by (a) } \\
\text { eliminating exemptions from the definition of 'exposure' and 'related party'; (b) } \\
\text { enhancing the scope of regulation to include non-credit transactions with related } \\
\text { parties; (c) ensuring that all interested parties not only disclose their interests but } \\
\text { also exclude themselves from the process of granting, managing, and resolving } \\
\text { related party exposures; and (d) explicitly laying down the requirements for } \\
\text { managing and reporting NPLs in related party transactions. }\end{array}$ \\
\hline $\begin{array}{l}\text { 12. Country and } \\
\text { transfer risks }\end{array}$ & $\begin{array}{l}\text { BI regulations and supervision do not address country and transfer risk. BI must } \\
\text { address this regulatory gap and enhance supervisory capacity. }\end{array}$ \\
\hline
\end{tabular}




\begin{tabular}{|c|c|}
\hline Core Principles & Comments \\
\hline 13. Market risk & $\begin{array}{l}\text { BI may consider extending the definition of trading portfolio to include the } \\
\text { available for sale (AFS) portfolio, if banks are found to trade from that portfolio. BI } \\
\text { must revise its guidelines on stress testing to explicitly require banks to factor the } \\
\text { outcomes into their risk management practices and policies, and also require } \\
\text { banks to draw up robust contingency plans for dealing with stress situations, } \\
\text { should they arise. }\end{array}$ \\
\hline 14. Liquidity risk & $\begin{array}{l}\text { BI must review the existing regulations and consider (a) explicitly requiring banks } \\
\text { to manage foreign currency liquidity risk, (b) laying down the standards or } \\
\text { benchmarks for slotting the various items of assets and liabilities, to enable } \\
\text { meaningful aggregation and inter-bank comparison; and (c) explicitly requiring } \\
\text { banks to inform the BI when their contingency funding plans (CFPs) are triggered } \\
\text { or when they are facing liquidity problems. Additionally, BI must ensure effective } \\
\text { implementation by banks of various elements of their guidelines issued in July } \\
2009 \text { with particular reference to diversification of funding sources, stress testing, } \\
\text { and validity of their CFPs. }\end{array}$ \\
\hline 15. Operational risk & $\begin{array}{l}\text { BI regulations and supervision of operational risk must be reviewed to include } \\
\text { explicitly outsourcing risk, business continuity planning in areas other than IT, } \\
\text { legal risk in banks below the threshold, and supervisory reporting of significant } \\
\text { operational risk events. }\end{array}$ \\
\hline $\begin{array}{l}\text { 16. Interest rate risk in } \\
\text { the banking book }\end{array}$ & $\begin{array}{l}\text { BI regulations and supervision do not cover this risk explicitly and } \\
\text { comprehensively, and banks are also not actively managing it. BI must address } \\
\text { this regulatory gap and enhance supervisory capacity. }\end{array}$ \\
\hline $\begin{array}{l}\text { 17. Internal control and } \\
\text { audit }\end{array}$ & $\begin{array}{l}\text { BI should adopt appropriate remedial measures to explicitly require a risk based } \\
\text { audit framework in banks, assess the internal control function as a separate } \\
\text { function in its entirety, and ensure that banks' internal control functions have the } \\
\text { capacity as well as methodologies for validating internal models, and stress } \\
\text { testing. }\end{array}$ \\
\hline $\begin{array}{l}\text { 18. Abuse of financial } \\
\text { services }\end{array}$ & $\begin{array}{l}\text { The APG } 2008 \text { mutual evaluation has revealed several gaps that can expose the } \\
\text { banking system either directly or indirectly to abuse. BI has addressed a few gaps } \\
\text { identified by the evaluation through revised regulations. The remaining gaps } \\
\text { identified in the above evaluation and effective implementation of the recent } \\
\text { initiatives by banks need to be addressed. }\end{array}$ \\
\hline $\begin{array}{l}\text { 19. Supervisory } \\
\text { approach }\end{array}$ & $\begin{array}{l}\text { BI needs to undertake formal and comprehensive reviews of banking system } \\
\text { trends that will help to detect emerging problems or to identify areas that may } \\
\text { need a greater supervisory focus. The existing risk based framework would } \\
\text { benefit from a sharper focus on consolidated supervision methods, techniques, } \\
\text { and procedures. Development and internal sharing of supervisory benchmarks } \\
\text { with regard to various performance indicators and the level of compliance with } \\
\text { regulatory requirements at bank level, peer group level, and at the level of } \\
\text { banking system, will immensely improve the quality of supervision. }\end{array}$ \\
\hline $\begin{array}{l}\text { 20. Supervisory } \\
\text { techniques }\end{array}$ & $\begin{array}{l}\text { Specific MOUs with other domestic supervisory agencies and ensuring effective } \\
\text { legal protection to supervisors would enhance supervisory efficiency. }\end{array}$ \\
\hline $\begin{array}{l}\text { 21. Supervisory } \\
\text { reporting }\end{array}$ & $\begin{array}{l}\text { Bl should consider requiring banks to report on a solo and consolidated basis in } \\
\text { respect of all areas of major risks. Peer group analysis should be improved to } \\
\text { make it more efficient and useful. At some point, horizontal examinations of a } \\
\text { cross-section of banks may be useful to make comparisons and spread best } \\
\text { practices throughout the industry. }\end{array}$ \\
\hline
\end{tabular}




\begin{tabular}{|c|c|}
\hline Core Principles & Comments \\
\hline $\begin{array}{l}\text { 22. Accounting and } \\
\text { disclosure }\end{array}$ & $\begin{array}{l}\text { In light of the gaps and weaknesses in the accounting and auditing standards in } \\
\text { Indonesia, BI needs to focus more supervisory resources on ensuring that banks' } \\
\text { financial statements reflect their true financial performance and financial position. } \\
\text { It should also develop a process to ensure a stringent quality assurance review of } \\
\text { bank audits and auditors. The implementation of IAS } 32 \text { and } 39 \text { equivalents in } \\
2010-11 \text { can be tricky and needs close monitoring by BI. There is ample scope for } \\
\text { improving disclosures by both banks and the BI to promote the availability and } \\
\text { comparability of banks' audited financial condition. }\end{array}$ \\
\hline $\begin{array}{l}\text { 23. Corrective and } \\
\text { remedial powers of } \\
\text { supervisors }\end{array}$ & $\begin{array}{l}\text { The existing prompt corrective action is largely discretionary. One efficient way to } \\
\text { promote a less discretionary approach and portray BI as a responsive institution is } \\
\text { to build in certain objective and automatic triggers into this framework. } \\
\text { Supervisors have a large arsenal of powers, but methodologies for consistency, } \\
\text { proper moderation or escalation were not evident. To ensure compliance, BI also } \\
\text { needs to put in place appropriate governance mechanisms. }\end{array}$ \\
\hline $\begin{array}{l}\text { 24. Consolidated } \\
\text { supervision }\end{array}$ & $\begin{array}{l}\text { BI needs to enhance the scope of consolidation, promote consistency in the } \\
\text { application of consolidated supervision, and develop effective operating } \\
\text { arrangements for information sharing and coordination with the relevant } \\
\text { supervisors (domestic and foreign). Prudential requirements and consolidated } \\
\text { reporting in all relevant areas can improve the quality of supervision. BI must pay } \\
\text { greater attention to the oversight of Indonesian banks' foreign operations by the } \\
\text { banks' management. }\end{array}$ \\
\hline $\begin{array}{l}\text { 25. Home-host } \\
\text { relationships }\end{array}$ & $\begin{array}{l}\text { BI must identify systemically important foreign institutions, make a determination } \\
\text { as to whether the home country supervisor is competent and has the authority to } \\
\text { enter into information sharing agreements, and ensure a regular program of visits } \\
\text { to the home supervisors. As many jurisdictions must have a formal agreement in } \\
\text { place to convey privileged supervisory information, BI will need to enter into } \\
\text { formal agreements with the relevant home supervisors to ensure effective } \\
\text { supervision of foreign bank operations. }\end{array}$ \\
\hline
\end{tabular}

\section{Response by the authorities}

39. The Republic of Indonesia welcomes the in-depth assessment by the IMF and World Bank team on the strengths and vulnerabilities of our banking sector. The assessment confirms Indonesia's compliance with a vast majority of the Basel Core Principles for Effective Bank Supervision. We broadly concur with the overall findings - beyond a few exceptions- and we plan to utilize the assessment as a blueprint to enhance our legislative, regulatory, and supervisory framework. Notwithstanding the above, we do have several clarifying remarks as outlined below:

40. Preconditions: The authorities are aware of the issues raised in the "preconditions" section of the assessment in regards to accounting and auditing standards and Indonesia's legal framework governing creditor rights and collateral enforcement. Although both elements are outside of BI's jurisdiction and control, we have proactively taken steps to minimize its consequences for banking sector oversight.

41. Accounting standards. First, there has been a steady trend of convergence between Indonesian and international accounting standards; and by 2012 all remaining gaps will be closed. That said, one should also recognize that "blindly" following the march towards meeting international accounting standards may or may not be in each country's national interests, particularly if local market conditions do not lend itself to a move towards greater use of "fair value" accounting -which implicitly assumes the existence of an underlying, liquid market for 
various asset classes. In this regard, the pressure for each country to converge with international accounting standards - through for example, the publication of ROSC assessments - without a better appreciation of the country context, needs to be re-evaluated. Second, Bank Indonesia has secured a seat within Indonesia's accounting standards setting body, and it uses its unique vantage point as a banking authority, to regularly voice concerns on any identified gaps in the application of accounting practices. Third, we concur that strengthening auditor competency continues to be a work in progress; in the meantime, we have imposed a range of unilateral actions on this issue, including the maintenance of a list of authorized auditors; and a required rotation of external audit firms at the same bank beyond a certain period of time.

42. Legal framework and credit rights: We also concur with the identified shortcomings in the legal-foreclosure framework in Indonesia. At BI, we have taken a number of steps to mitigate the prudential concerns associated with the protracted court resolution process, particularly with respect to the valuation of problem loans. Our loan loss provisioning framework requires banks to establish loss buffers for performing loans -that ignores the value of any collateral; and it applies significant haircuts to collateral - 30 percent up to 100 percent of appraised value- for all other types of loans, for purposes of establishing the minimum amount of required loss provisions. This minimum regulatory standard, is measured against how much loss buffers would be required if banks applied the "time value" concept (e.g., the estimated time it takes to foreclose and liquidate collateral under IAS 39), with the higher of the two approaches, reflected in each banks' capital adequacy calculation (as a deduction to Tier 1 capital). With respect to securing collateral, several prerequisites have been imposed in order to mitigate any legal risk that may arise at the time of foreclosure. These prerequisite covers aspect as valid legal documentation, securing legal rights and first lien to the collateral as well as insurance coverage. Throughout all these processes, BI attempts to explicitly integrate the lengthy foreclosure process into its regulatory and supervisory framework.

43. The lack of appropriate gateways for information exchange with domestic and foreign supervisory authorities: BI has recently signed MOUs with other domestic regulatory authorities to establish a formal mechanism to share supervisory information across the key financial sector regulators. It should be noted, however, that the lack of formal information sharing arrangements did not materially impede our practice of consolidated supervision, as noted in the overall assessment of consolidated supervision. In regards to information sharing with foreign supervisory authorities, we agree that further efforts are needed; but those efforts must be conducted at a multilateral level, given the inherently unequal relationship between the "host" and "home" country authorities.

44. Capital Adequacy. While we concur with the need to strengthen some aspects of our capital regime, a better contextual explanation is warranted. First, the eligibility of certain capital components that are in question, are either immaterial and/or do not have a clear international standard, and practices across jurisdictions vary (e.g. - for example, the inclusion of 50 percent of unaudited profits in Tier 1 capital, and the nature of foreign branch capital). If Indonesia were to unilaterally change its definition of capital -to exclude items that are considered as eligible capital items in other jurisdictions- it raises level playing field concerns. Finally, the noted dilutions to the "risk-weights" are still within the parameters allowed under Basel II.

45. Problem assets, provisions, and reserves. While we concur that there are some gaps in our overall system of classification and provisioning, our application of a minimum regulatory provisioning matrix -that is subject to supervisory review- is well within international norms of 
other countries that apply such a framework. In addition, our supervisory review process assesses and makes necessary modifications to both reported asset quality and adequacy of provisions during the on-site examination process.

46. Definition of single borrower, borrower group, related party exposures. Indonesia has one of the most stringent coverage in terms of the definition of single borrower, borrower group and related party. The coverage is very extensive in that it covers almost all level of the bank's group structure as well is direct and indirect transactions, which in our view is comparable to even the scope utilized by developed economies. To tighten more the definition coverage would have significant consequences with respect to the intermediation function in the Indonesian economy given the fact that the banking sector accounts for almost 80 percent of the total financial system, the level of development of the financial market, and that the structure of companies in the economy is tied within a large conglomeration structure.

47. Liquidity risk. With regards to the recommendations made by the assessor that BI regulations should prescribe standards for slotting various assets and liabilities, from our vantage point, we do not believe there is one "right" method to follow, and it largely depends on one's prevailing regulatory and supervisory philosophy. Meanwhile, with regards to the recommendation on CFP, although this is very formalistic, we will take the recommendation under advisement. In practice our supervisors -through ongoing supervision- will know whether a bank is experiencing liquidity difficulties.

48. IRRBB. Although BI has yet to issue regulations on the management of IRRBB, BI has addressed this under capital adequacy, asset quality, management quality, earnings, liquidity, and sensitivity to market risk (CAMELS) regulation, whereby banks are required to maintain their soundness rating taking into account the sensitivity of market risks, covering interest rate risk in banking and trading book. Some larger banks have developed their framework and system to manage IRRBB for internal management purposes. In the near term, BI will be issuing consultative paper on this particular topic to be further addressed under the Pillar 2 of Basel II.

49. Internal control and audit. While we concur that the framework for internal control and audit needs to be improved, however we are of the view that the "piecemeal" approach generally used in examination comes about as a consequence of the adoption of the risk based framework that BI has started to implement. This is not to say that BI do not undertake comprehensive internal control audit. Assessment of the adequacy of the whole internal audit function is a necessity and form an integral part of the risk control system evaluations of banks performed by supervisors. On top of that BI required auditors to perform an assessment of a bank's internal control function prior to performing internal audit. Banks are also obliged to periodically utilize an independent reviewer to review its overall internal control and audit function, which results are then submitted to BI. Throughout all these processes, BI attempts to explicitly integrate the various approaches in reviewing the internal control and audit function in order for supervisors to have the necessary information with regards to the effectiveness control system of banks.

\section{Detailed ASSESSMENT}

50. The ratings for compliance were awarded according to the methodology prescribed in the BCBS document - Core Principles Methodology (October 2006). This methodology established four levels of compliance: compliant, largely compliant, materially non-compliant, 
and non-compliant. The criteria for awarding these four ratings are as follows:

- Compliant - This rating implies that all essential criteria applicable for this country are met without any significant deficiencies. There may be instances, of course, where a country can demonstrate that the Principle has been achieved by other means. Conversely, due to the specific conditions in individual countries, the essential criteria may not always be sufficient to achieve the objective of the Principle, and therefore other measures may also be needed for the aspect of banking supervision addressed by the Principle to be considered effective.

- Largely compliant - This rating will imply that only minor shortcomings are observed which do not raise any concerns about the authority's ability and clear intent to achieve full compliance with the Principle within a prescribed period of time. The assessment "largely compliant" can be used when the system does not meet all essential criteria, but the overall effectiveness is sufficiently good, and no material risks are left unaddressed.

- Materially non-compliant - This rating implies that there are severe shortcomings, despite the existence of formal rules, regulations and procedures, and there is evidence that supervision has clearly not been effective, that practical implementation is weak, or that the shortcomings are sufficient to raise doubts about the authority's ability to achieve compliance. It is acknowledged that the "gap" between "largely compliant" and "materially non-compliant" is wide, and that the choice may be difficult. On the other hand, the intention has been to force the assessors to make a clear statement.

- Non-compliant - This rating implies that there has been no substantive implementation of the Principle, several essential criteria are not complied with or supervision is manifestly ineffective. 
Table 4. Detailed Assessment of Compliance with the Basel Core Principles

\begin{tabular}{|c|c|}
\hline Principle 1. & $\begin{array}{l}\text { Objectives, independence, powers, transparency, and cooperation. An effective } \\
\text { system of banking supervision will have clear responsibilities and objectives for each } \\
\text { authority involved in the supervision of banks. Each such authority should possess } \\
\text { operational independence, transparent processes, sound governance and adequate } \\
\text { resources, and be accountable for the discharge of its duties. A suitable legal } \\
\text { framework for banking supervision is also necessary, including provisions relating to } \\
\text { authorization of banking establishments and their ongoing supervision; powers to } \\
\text { address compliance with laws as well as safety and soundness concerns; and legal } \\
\text { protection for supervisors. Arrangements for sharing information between supervisors } \\
\text { and protecting the confidentiality of such information should be in place. }\end{array}$ \\
\hline Principle 1(1) & $\begin{array}{l}\text { Responsibilities and objectives: An effective system of banking supervision will have } \\
\text { clear responsibilities and objectives for each authority involved in the supervision of } \\
\text { banks. }\end{array}$ \\
\hline \multirow[t]{8}{*}{ Description } & $\begin{array}{l}\text { Essential Criterion 1: Laws are in place for banking, and for the authority (each of the } \\
\text { authorities) involved in banking supervision. The responsibilities and objectives of each } \\
\text { of the authorities are clearly defined and publicly disclosed. }\end{array}$ \\
\hline & $\begin{array}{l}\text { The Republic Indonesia Act No. } 23 \text { is commonly known as the Bank Indonesia Act. The } \\
\text { Act clearly spells out Bl's responsibilities with respect to the supervision of banks. } \\
\text { Regulations implementing the Act cover licensing, supervision, and sanctioning powers. }\end{array}$ \\
\hline & $\begin{array}{l}\text { Essential Criterion 2: The laws and supporting regulations provide a framework of } \\
\text { minimum prudential standards that banks must meet. }\end{array}$ \\
\hline & $\begin{array}{l}\mathrm{BI} \text { regulations generally cover the range of prudential standards. A review of } \mathrm{BI} \\
\text { regulations confirms that the framework of prudential standards is comprehensive and } \\
\text { broadly meets minimum standards. }\end{array}$ \\
\hline & $\begin{array}{l}\text { Essential Criterion 3: Banking laws and regulations are updated as necessary to ensure } \\
\text { that they remain effective and relevant to changing industry and regulatory practices. }\end{array}$ \\
\hline & $\begin{array}{l}\text { The last amendment to the Banking Act was in } 1998 \text { and is currently in the process of } \\
\text { being revised. It is clear that BI updates regulations and guidelines to keep them relevant } \\
\text { and current. }\end{array}$ \\
\hline & $\begin{array}{l}\text { Essential Criterion 4: The supervisor confirms that information on the financial strength } \\
\text { and performance of the industry under its jurisdiction is publicly available. }\end{array}$ \\
\hline & $\begin{array}{l}\text { Banks are required to make financial and performance information public on a quarterly } \\
\text { basis in line with norms. BI publishes periodically statistical reports on banks and } \\
\text { financial stability reports that contain aggregate information on the banking system. }\end{array}$ \\
\hline Assessment & Compliant \\
\hline Comments & -- \\
\hline Principle 1(2) & $\begin{array}{l}\text { Independence, accountability and transparency. Each such authority should } \\
\text { possess operational independence, transparent processes, sound governance and } \\
\text { adequate resources, and be accountable for the discharge of its duties. }\end{array}$ \\
\hline Description & $\begin{array}{l}\text { Essential Criterion 1: The operational independence, accountability and governance } \\
\text { structures of each supervisory authority are prescribed by law and publicly disclosed. }\end{array}$ \\
\hline
\end{tabular}


There is, in practice, no evidence of government or industry interference which compromises the operational independence of each authority, or in each authority's ability to obtain and deploy the resources needed to carry out its mandate. The head(s) of the supervisory authority can be removed from office during his (their) term only for reasons specified in law. The reason(s) for removal should be publicly disclosed.

Independence is contained in the $\mathrm{BI}$ Act. During the assessment there was no evidence of political interference with respect to operational independence. Removal procedures are consistent with good practice and contained in the $\mathrm{BI}$ act. The broad reasons for which the Governor might be removed from office during his tenure are specified in the law (Article 48(1) of BI Act). While the removal is disclosed, the reason for the removal is not disclosed.

Essential Criterion 2: The supervisor publishes objectives and is accountable through a transparent framework for the discharge of its duties in relation to those objectives.

The $\mathrm{BI}$ act requires annual disclosure to the public of an evaluation of the policies it has adopted to achieve its objectives as defined in law, along with intended goals and financial reporting. In addition, periodic visits to the House of Representatives accompany a quarterly report to that body where explanations may be given on matters pertaining to supervision.

Essential Criterion 3: The supervisory authority and its staff have credibility based on their professionalism and integrity.

The staff of $\mathrm{BI}$ in bank supervision is considered to be very professional and of high moral integrity. This was confirmed by interviews with selected banks.

Essential Criterion 4: The supervisor is financed in a manner that does not undermine its autonomy or independence and permits it to conduct effective supervision and oversight. This includes:

- a budget that provides for staff in sufficient numbers and with skills commensurate with the size and complexity of the institutions supervised;

- salary scales that allow it to attract and retain qualified staff;

- the ability to commission outside experts with the necessary professional skills and independence, and subject to necessary confidentiality restrictions to conduct supervisory tasks;

- a training budget and programme that provide regular training opportunities for staff;

- a budget for computers and other equipment sufficient to equip its staff with the tools needed to review the banking industry and assess individual banks and banking groups; and

- a travel budget that allows appropriate on-site work.

The operational budget of $\mathrm{BI}$ requires the yearly approval of Parliament, while the policy budget requires yearly reporting. While discussions may be contentious, the history has been that the budget is ultimately approved. BI can continue to operate without budget approval based on the prior year's approved budget. There are also sufficient contingency arrangements to deal with special events. The BI does not appear to be constrained in commissioning outside consultants if needed. Training funds are available and sufficient to provide the staff with reasonable opportunities. Salary and benefits are adequate evidenced by low turnover. 


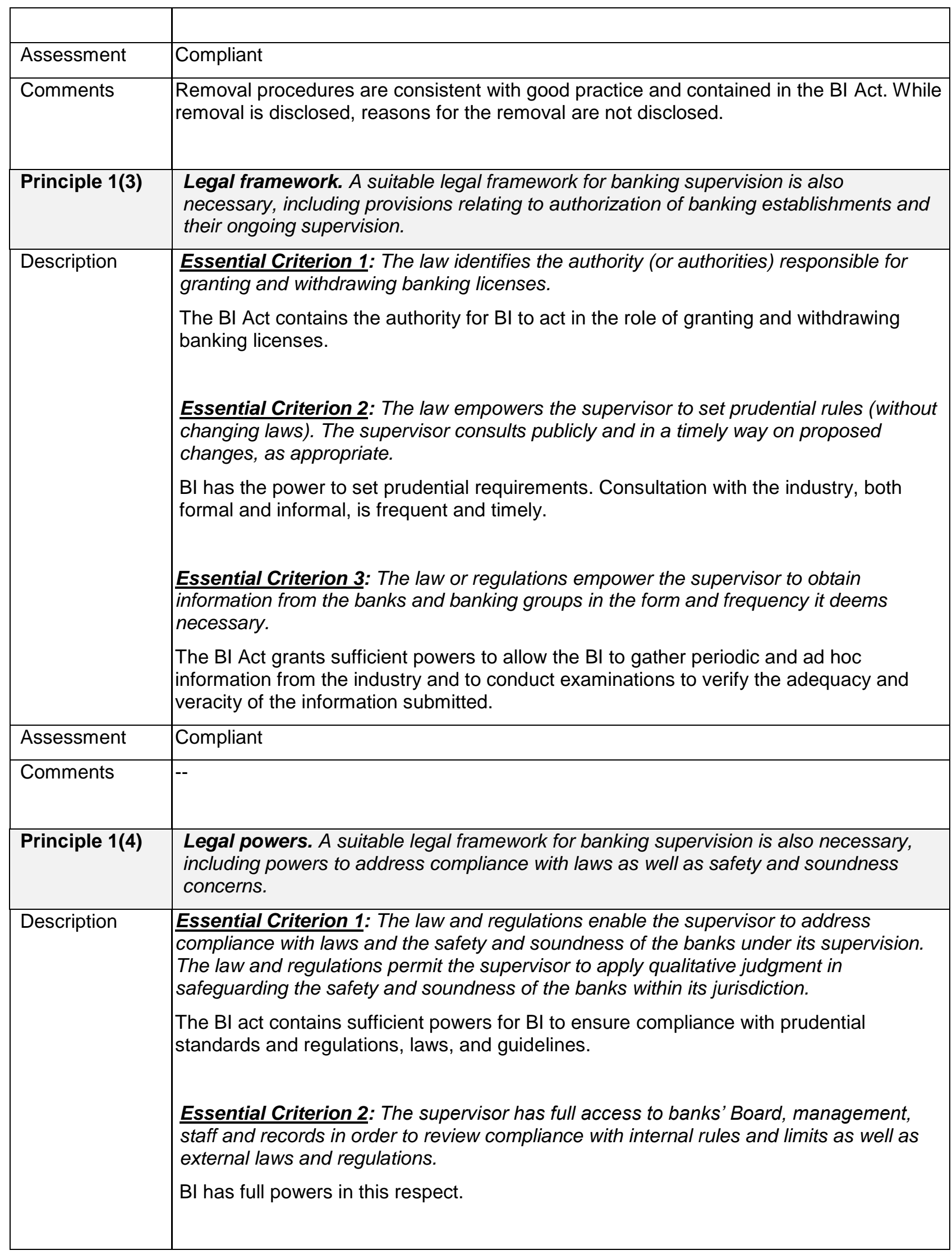




\begin{tabular}{|c|c|}
\hline & $\begin{array}{l}\text { Essential Criterion 3: When, in a supervisor's judgment, a bank is not complying with } \\
\text { laws or regulations, or it is or is likely to be engaged in unsafe or unsound practices, the } \\
\text { supervisor has the power to: } \\
\text { - take (and/or require a bank to take) prompt remedial action; and } \\
\text { - impose a range of sanctions (including the revocation of the banking license). } \\
\text { BI has full powers to enforce compliance and has a range of powers sufficient to address } \\
\text { any given situation up to and including revocation of a license. }\end{array}$ \\
\hline Assessment & Compliant \\
\hline Comments & -- \\
\hline Principle 1(5) & $\begin{array}{l}\text { Legal protection. A suitable legal framework for banking supervision is also } \\
\text { necessary, including legal protection for supervisors. }\end{array}$ \\
\hline & $\begin{array}{l}\text { Essential Criterion 1: The law provides protection to the supervisory authority and its } \\
\text { staff against lawsuits for actions taken and/or omissions made while discharging their } \\
\text { duties in good faith. } \\
\text { The BI Act contains provisions under Article } 45 \text { that protect supervisory staff (Governor, } \\
\text { Deputy Governors, Directors, and staff) from legal prosecution for any actions or } \\
\text { decisions made in 'good faith' when performing their supervisory duties. The Elucidation } \\
\text { to this Article defines 'Good faith' as : } \\
\text { >action is not related to family } \\
\text { >action has a positive impact } \\
\text { >action is timely } \\
\text { >action is within procedures } \\
\text { The Law does not provide presumption of good faith in favour of supervisory staff. } \\
\text { Consequently, the four requirements to meet "good faith", which are not a standard } \\
\text { definition of the term, are too onerous to meet and place a higher burden of proof on the } \\
\text { supervisory staff. Consequently, this effectively negates protection to the supervisory } \\
\text { staff. } \\
\text { The provisions under Article } 45 \text { do not include omission, which can be a cause of legal } \\
\text { action. } \\
\text { The usual standards of protection should include immunity for supervisory staff from } \\
\text { being personally liable to law suits and damages arising therefrom. } \\
\text { Another defect in Article } 45 \text { is that it does not provide legal protection to the BI as the } \\
\text { supervisory authority. } \\
\text { Essential Criterion 2: The supervisory authority and its staff are adequately protected } \\
\text { against the costs of defending their actions and/or omissions made while discharging } \\
\text { their duties in good faith. } \\
\text { Legal protection is available to the supervisory staff under the BI Act in the form of legal } \\
\text { consultations, legal assistance, accessibility to data, and information and security } \\
\text { assistance to them and their families. Law and regulations do not protect the BI, as a } \\
\text { supervisory authority, against the costs of defending its actions or omissions. }\end{array}$ \\
\hline Assessment & Materially non-compliant \\
\hline
\end{tabular}




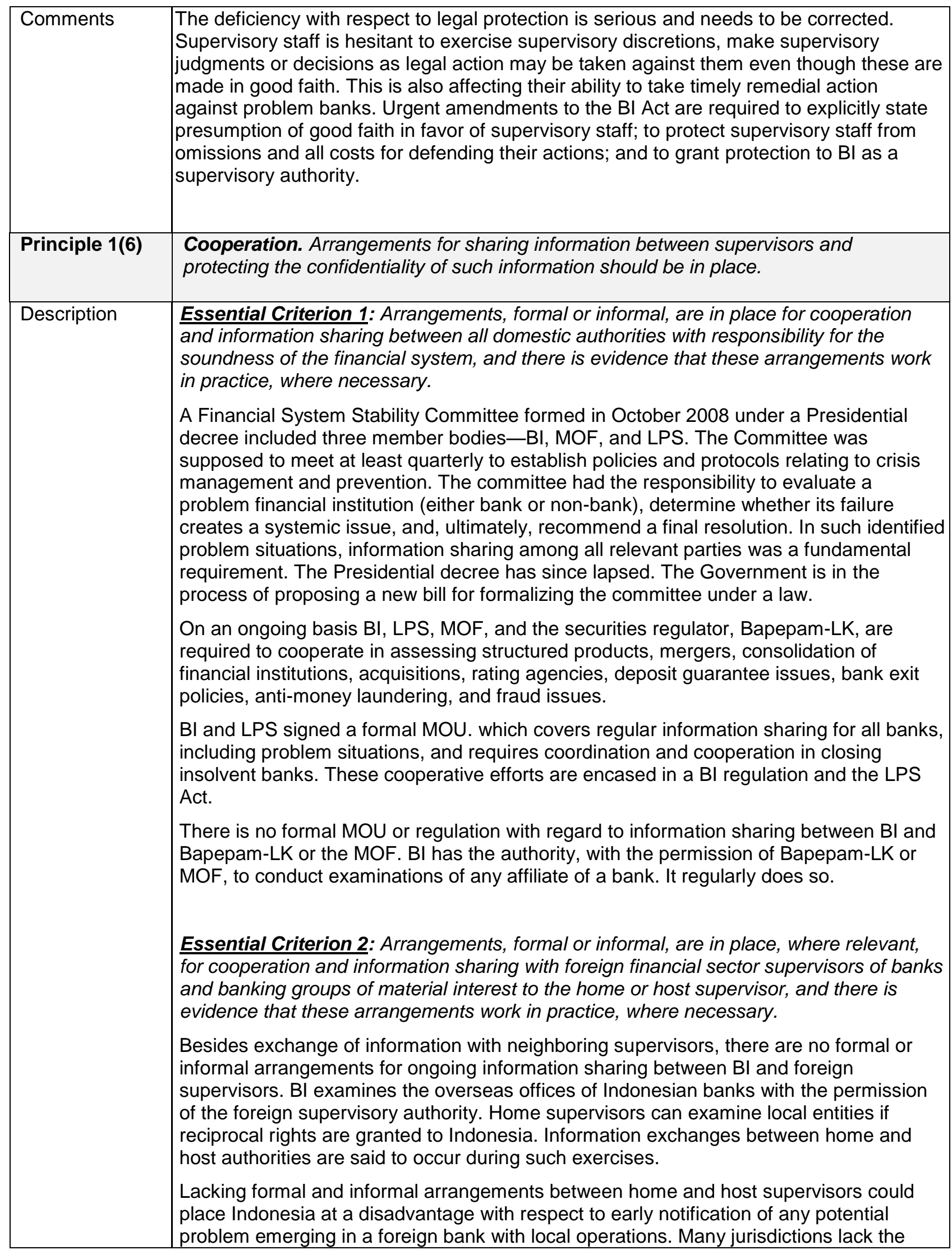




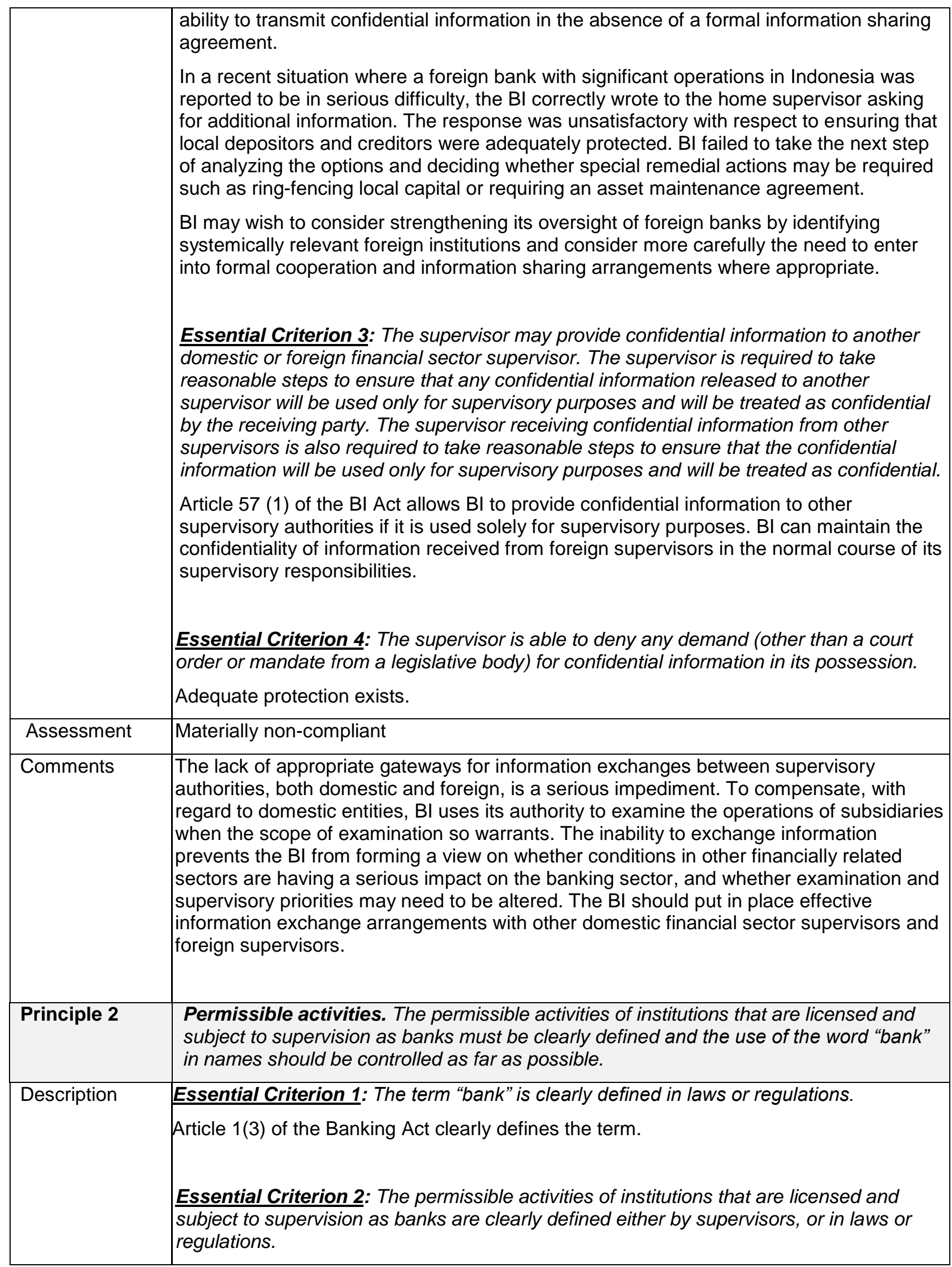




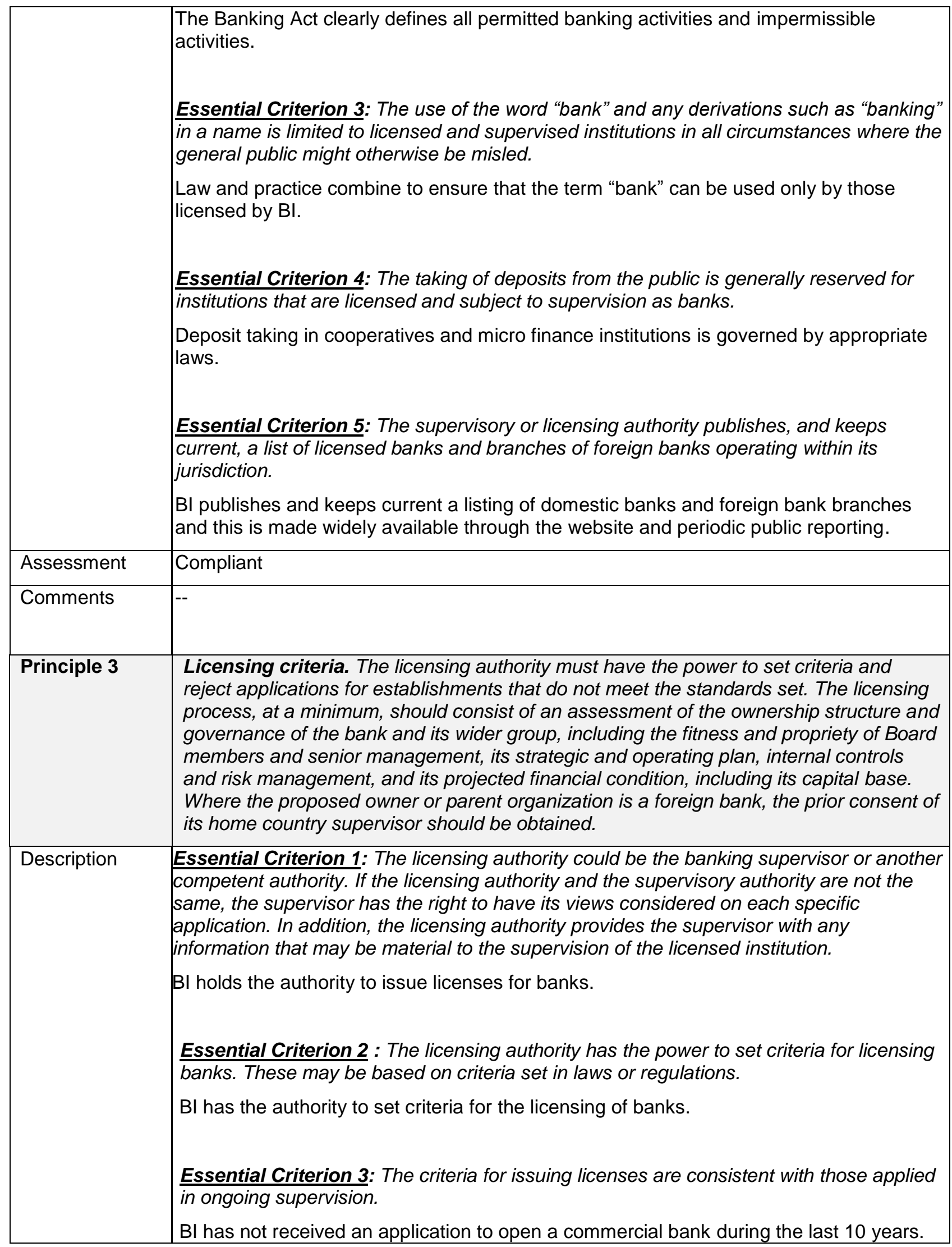


The criteria for issuing a license are similar to those used in ongoing supervision.

Essential Criterion 4: The licensing authority has the power to reject an application if the criteria are not fulfilled or if the information provided is inadequate.

$\mathrm{BI}$ has not received an application to open a commercial bank in 10 years. BI could reject an application for cause.

Essential Criterion 5: The licensing authority determines that the proposed legal, managerial, operational and ownership structures of the bank and its wider group will not hinder effective supervision on both a solo and a consolidated basis.

The authority exists but there has been no application for a banking license since 1999.

Essential Criterion 6: The licensing authority identifies and determines the suitability of major shareholders, including the ultimate beneficial owners, and others that may exert significant influence. It also assesses the transparency of the ownership structure and the sources of initial capital.

No applications have been acted on since 1999. BI has the authority to prevent opaque structures and to adequately vet all major shareholders.

Essential Criterion 7: A minimum initial capital amount is stipulated for all banks.

Minimum initial capital for setting up a new bank is IDR 3 trillion (USD 300 million).

Essential Criterion 8: The licensing authority, at authorization, evaluates proposed directors and senior management as to expertise and integrity (fit and proper test), and any potential for conflicts of interest. The fit and proper criteria include: (i) skills and experience in relevant financial operations commensurate with the intended activities of the bank; and (ii) no record of criminal activities or adverse regulatory judgments that make a person unfit to uphold important positions in a bank.

The $\mathrm{BI}$ has not received an application to open a commercial bank during the last 10 years. Fit and proper evaluation processes appear in line with listed criteria.

Essential Criterion 9: The licensing authority reviews the proposed strategic and operating plans of the bank. This includes determining that an appropriate system of corporate governance, risk management and internal controls, including those related to the detection and prevention of criminal activities, as well as the oversight of proposed outsourced functions, will be in place. The operational structure is required to reflect the scope and degree of sophistication of the proposed activities of the bank.

BI has the authority, but no license has been granted since 1999.

Essential Criterion 10: The licensing authority reviews pro forma financial statements and projections for the proposed bank. This includes an assessment of the adequacy of the financial strength to support the proposed strategic plan as well as financial information on the principal shareholders of the bank.

No application has been submitted in 10 years. 


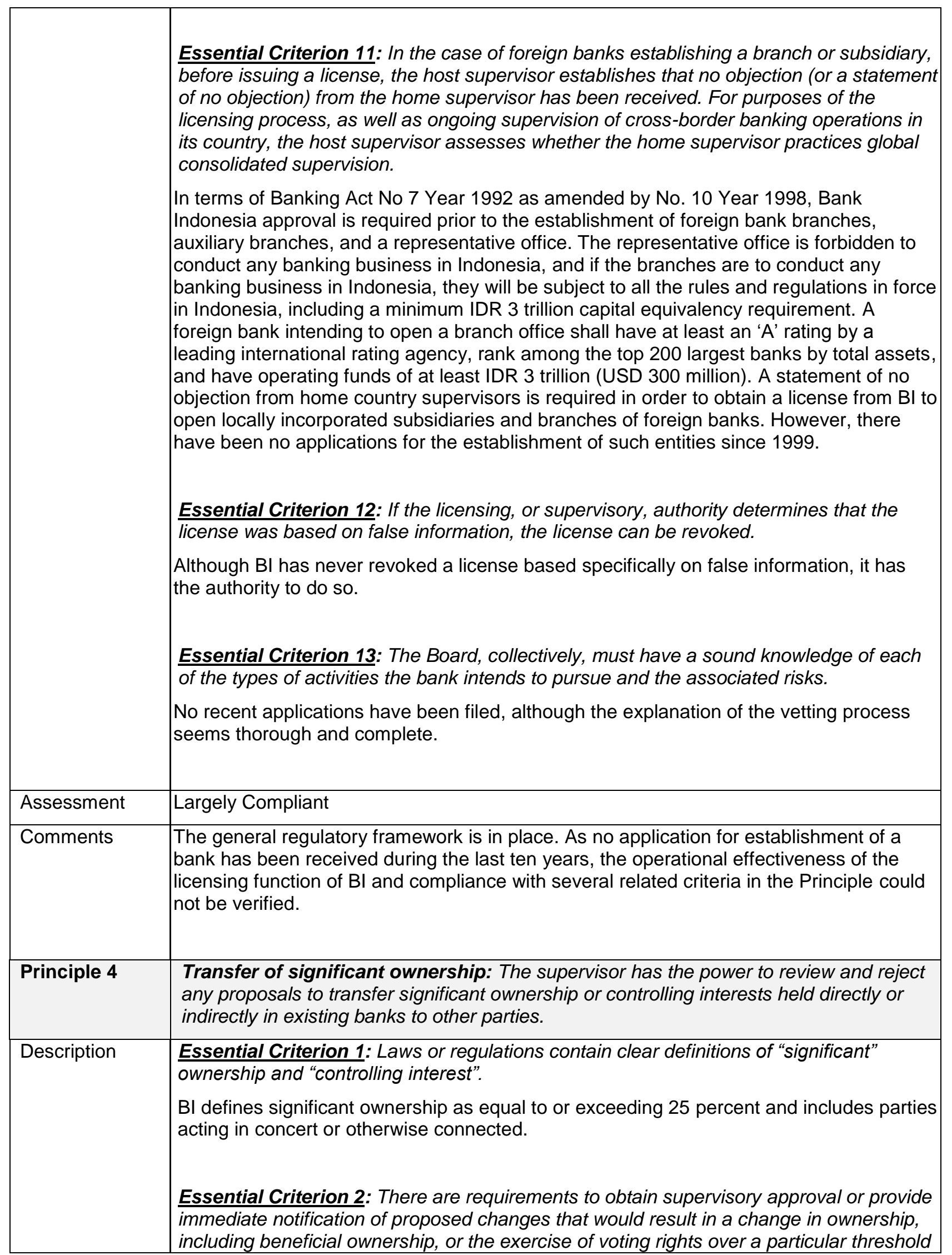




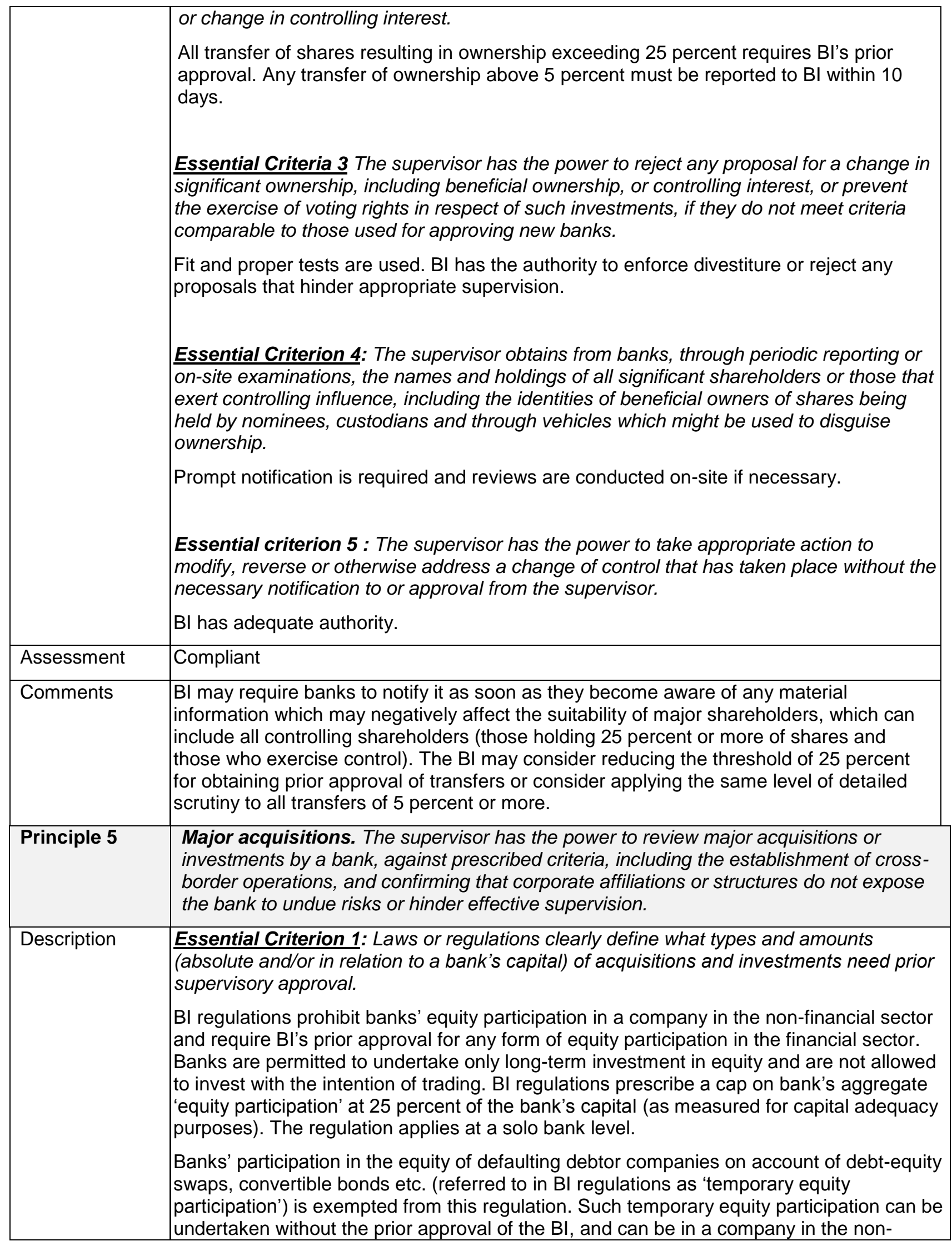


financial sector also.

Essential Criterion 2: Laws or regulations provide criteria by which to judge individual proposals.

Regulations provide detailed criteria for a bank to qualify to invest in equity. Regulations also stipulate the details required to be submitted by banks. The criteria for processing proposals from banks generally include viability of the investee entity, banks' capacity to manage the risks, and compliance with the prudential limits prescribed for (a) related party exposures, (b) single borrower exposure, (c) group borrower exposure (referred to as legal lending limits in BI regulations), and (d) 'equity participation'.

Essential Criterion 3: Consistent with the licensing requirements, among the objective criteria that the supervisor uses is that any new acquisitions and investments do not expose the bank to undue risks or hinder effective supervision. The supervisor can prohibit banks from making major acquisitions/investments (including the establishment of foreign branches or subsidiaries) in countries with secrecy laws or other regulations prohibiting information flows deemed necessary for adequate consolidated supervision.

Please see description under EC 1 and 2.

Regulations require a bank to divest its equity investment if it results in or is expected to result in a significant reduction in the bank's capital and / or significant increase in the risk profile. It empowers $\mathrm{BI}$ to enforce divestment of any existing equity participation, or reject any equity participation proposal made by banks, if the mentioned participation will hinder the supervisory process.

Essential Criterion 4: The supervisor determines that the bank has, from the outset, adequate financial and organizational resources to handle the acquisition/investment. Please see description under EC 2.

Regulations also require banks to have (a) appropriate policies, procedures and processes for managing equity investments, and (b) appropriate internal control mechanisms. The equity risk management system in banks is required to be periodically reviewed, to ensure its adequacy, effectiveness as well as its suitability for dealing with any developments in the banks or surrounding economic environment.

Essential Criterion 5: Laws or regulations clearly define for which cases notification after the acquisition or investment is sufficient. Such cases should primarily refer to activities closely related to banking and the investment being small relative to the bank's capital.

Banks are required to obtain Bl's prior approval for all strategic equity investments in entities in the financial sector and these investments are subject to the various limits as applicable to equity investments as well legal lending limits.

Banks' temporary equity participation does not require prior approval and can also be made in entities from the non-financial sector. Banks are not required to report such participations other than as part of their periodic off-site reports on the loan and investment portfolio.

Essential Criterion 6: The supervisor is aware of the risks that non-banking activities can pose to a banking group and has the means to take action to mitigate those risks. 


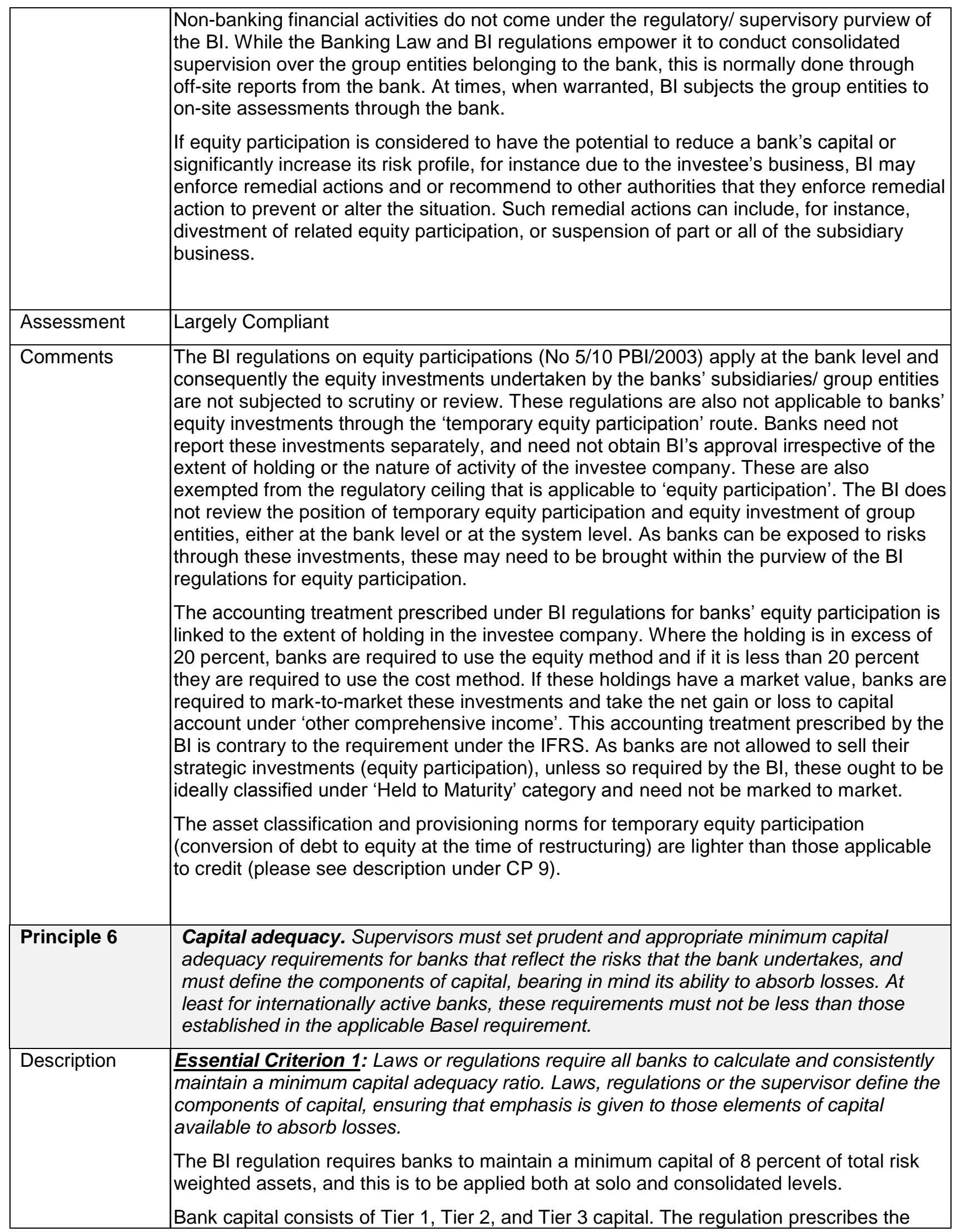


rules and eligibility requirements for these three variants of capital.

Tier 1 capital items include paid-up capital, disclosed reserves, eligible innovative capital, adjusted current year's profit, foreign currency translation gains, share warrants, and stock options. Banks are required to hold at the minimum 5 percent Tier 1 capital, and the maximum amount of innovative Tier 1 capital is set at 10 percent of Tier 1 capital. On a consolidated basis, minority interest will be accounted for as Tier 1 capital, subject to compliance with qualifying parameters.

Items that must be deducted for capital adequacy purposes include goodwill, other intangible assets, investment in subsidiaries, cross-holding of Tier 2 bonds and certain securitization exposures. While deducting investment in subsidiaries, banks need not deduct equity investments that are part of credit restructuring. The current year's profit is adjusted by first deducting net deferred tax assets (DTA), fixed assets revaluation gains, mark-to-market gains, and gains on the sale of securitized assets. Banks are allowed to recognize 50 percent of the resulting net amount of current year's profit as Tier 1 capital.

$\mathrm{BI}$ regulations require all banks to maintain capital for credit risk. Market risk capital charge is applicable to certain banks that meet specified criteria, viz. their total asset base is above IDR 1 trillion and their trading book size is above IDR 25 billion. As at end-

September 2009, about 58 banks that account for about 95 percent of banking assets and 99 percent of trading assets maintain capital for market risks. Of the 63 banks that are not required to maintain capital for market risks, two have a very small trading book and the others do not have any trading positions as at end-September 2009.

Essential Criterion 2: At least for internationally active banks, the definition of capital, the method of calculation and the ratio required are not lower than those established in the applicable Basel requirement.

Please see description under EC 1.

BI plans to implement Basel II for all commercial banks by adopting the simple approaches, i.e. the standardized approach (SA) for credit risk, the standardized maturity method for market risk, and the basic indicator approach (BIA) for operational risk. With reference to market risk, $\mathrm{BI}$ allows banks to use both the standard duration model and internal model, but only with prior supervisory approval. BI regulations also mention that banks may adopt the internal ratings based (IRB) approach for credit risk and advanced measurement approach (AMA) for operational risk, but after obtaining approval from the BI.

$\mathrm{BI}$ has issued regulations that are effective from January 1, 2009 requiring banks to maintain capital as per Basel II for credit risk, market risk, and operational risk. BI has issued guidelines for computing capital for operational risk that allow banks to comply with the requirement in phases from January 1, 2010 till January 1, 2011. BI has also issued guidelines for computing capital for market risk exposures. The guidelines on computing the capital charge for credit risk, credit risk aspects in the trading book, and Pillar 2 and Pillar 3 aspects are yet to be issued. The current timelines for implementation of Pillar 1 is 2011, Pillar 2 is 2012-2014, and Pillar 3 is 2011- 2014.

Consequently, the effective applicable international benchmark for assessing capital adequacy in Indonesian banks is Basel I.

The $\mathrm{BI}$ regulations for computing risk weighted assets for credit risk and market risk are largely as per the Basel I requirements. BI had modified the applicable risk weights for credit risk in certain categories of assets with effect from March 31, 2006, which are below the risk weights prescribed under the Basel I rules, as indicated in the table below : 


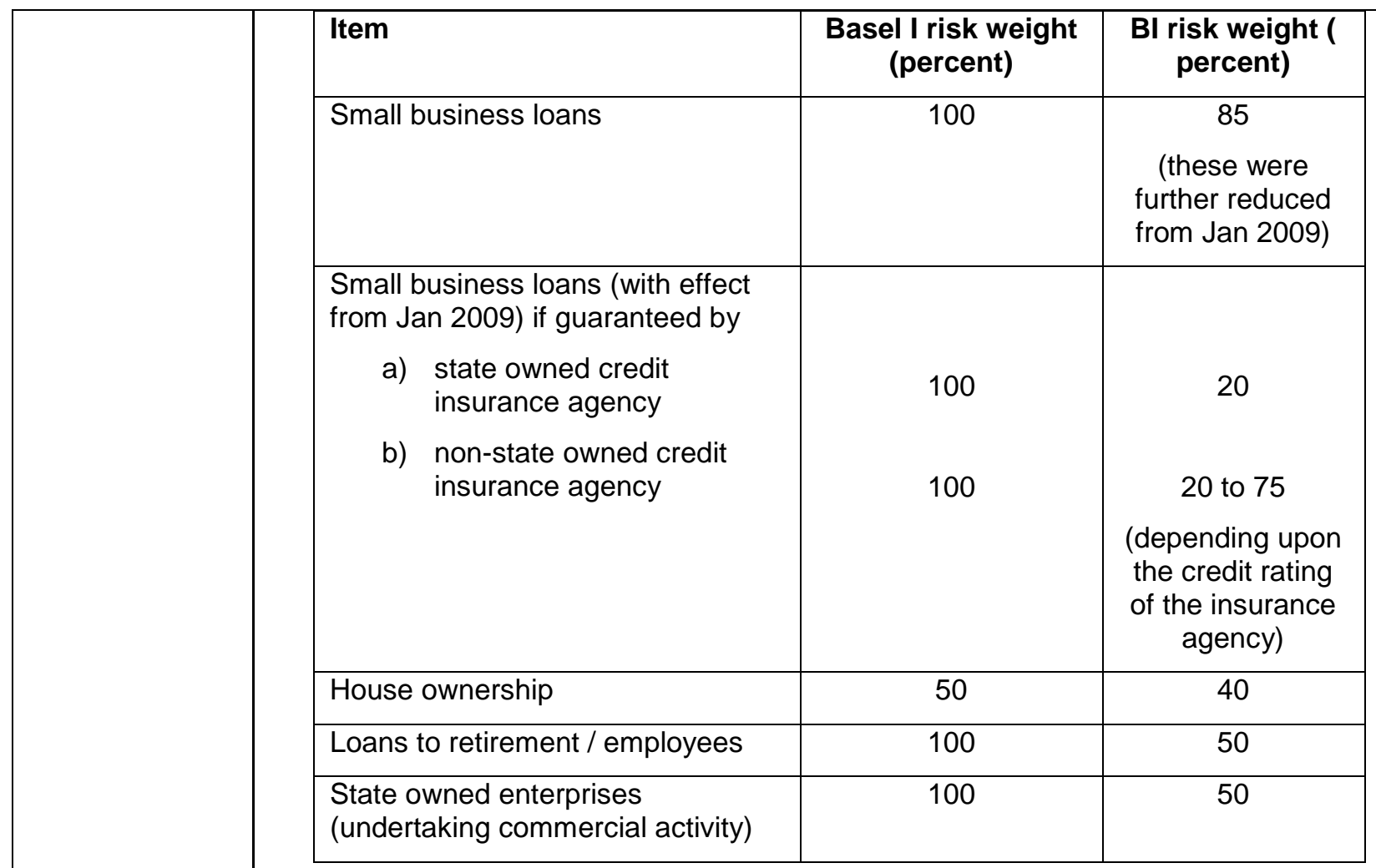

BI regulations do not require banks to assign a 100 percent risk weight for NPLs. Certain weaknesses in asset classification and provisioning (discussed under Principle 9) also have a bearing on banks' capital adequacy positions.

Essential Criterion 3: The supervisor has the power to impose a specific capital charge and/or limits on all material risk exposures.

$\mathrm{BI}$ has required banks to hold capital for credit risks (all banks) and market risk (for banks above a threshold).

BI regulations (Art 2(3) and 2(4)) on capital adequacy provide for the supervisor to require banks to hold capital in excess of the regulatory minimum of 8 percent. In practice, this regulatory power has not been formally invoked to date. However, it is understood that $\mathrm{BI}$ is encouraging the top 14 banks (accounting for about 70 percent of market share in terms of assets) to maintain a minimum capital adequacy ratio of 12 percent, through the suasion route.

Essential Criterion 4: The required capital ratio reflects the risk profile of individual banks. Both on-balance sheet and off-balance sheet risks are included.

The minimum capital requirement, applicable to all banks, is 8 percent of total risk weighted assets, reckoning both on-balance sheet assets and off-balance sheet items. The ratio is applied both at solo and consolidated levels.

Essential Criterion 5: Capital adequacy requirements take into account the conditions under which the banking system operates. Consequently, laws and regulations in a particular jurisdiction may set higher capital adequacy standards than the applicable Basel 


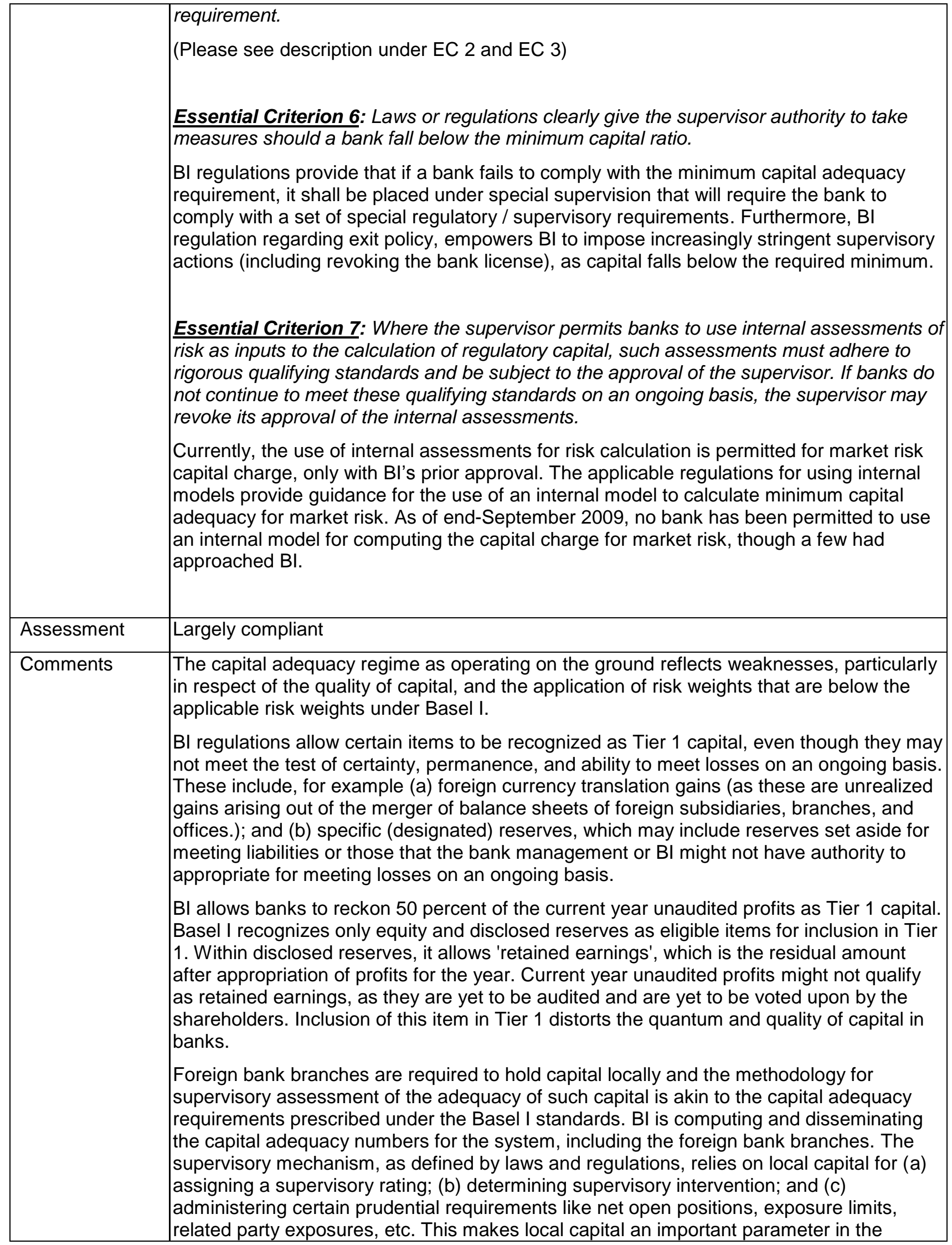




\begin{tabular}{|c|c|}
\hline & $\begin{array}{l}\text { supervisory framework for foreign bank branches. From this perspective, inter-office funds, } \\
\text { a primary form of Tier } 1 \text { capital held by foreign bank branches, induce day-to-day volatility } \\
\text { in the capital held by these branches. }\end{array}$ \\
\hline & $\begin{array}{l}\text { As regards deductions from capital, banks are required to deduct cross-holdings of Tier } 2 \\
\text { bonds, but the same has not been stipulated for equity, Tier } 1 \text { innovative capital, and Tier } \\
3 \text { bonds. }\end{array}$ \\
\hline & $\begin{array}{l}\text { The more liberal definition of capital, coupled with the dilution of risk weights (as } \\
\text { elaborated in the description under EC 2), and weaknesses in asset classification and } \\
\text { provisioning (as elaborated under CP 9) have resulted in inconsistencies with the Basel } \\
\text { principles. The observed weaknesses suggest that there is a need to adopt a more } \\
\text { prudent approach in establishing the requirements; and that the present requirements may } \\
\text { not appropriately capture the risks that the banks are assuming. }\end{array}$ \\
\hline & $\begin{array}{l}\text { BI should initiate appropriate remedial measures to address the above shortcomings and } \\
\text { ensure that the capital adequacy framework is consistent with the Basel I framework. }\end{array}$ \\
\hline & $\begin{array}{l}\text { In view of the systemic relevance of some banks, BI may consider formally requiring those } \\
\text { banks and banking groups to maintain capital above the minimum prescribed in the Basel } \\
\text { framework. BI should consider encouraging banks to adopt a forward looking approach } \\
\text { and factor stress test outcomes into their capital management framework. }\end{array}$ \\
\hline & $\begin{array}{l}\text { Full implementation of Basel II is expected from January 2014. Against this backdrop, } \mathrm{BI} \\
\text { should require banks to maintain capital adequacy in line with the Basel I norms until Pillar } \\
2 \text { and Pillar } 3 \text { of the Basel II framework are effectively operational. }\end{array}$ \\
\hline Principle 7 & $\begin{array}{l}\text { Risk management process. Supervisors must be satisfied that banks and banking } \\
\text { groups have in place a comprehensive risk management process (including Board and } \\
\text { senior management oversight) to identify, evaluate, monitor and control or mitigate all } \\
\text { material risks and to assess their overall capital adequacy in relation to their risk profile. } \\
\text { These processes should be commensurate with the size and complexity of the } \\
\text { institution. }\end{array}$ \\
\hline Description & $\begin{array}{l}\text { Essential Criterion 1: Individual banks and banking groups are required to have in place } \\
\text { comprehensive risk management policies and processes to identify, evaluate, monitor and } \\
\text { control or mitigate material risks. The supervisor determines that these processes are } \\
\text { adequate for the size and nature of the activities of the bank and banking group and are } \\
\text { periodically adjusted in the light of the changing risk profile of the bank or banking group } \\
\text { and external market developments. If the supervisor determines that the risk management } \\
\text { processes are inadequate, it has the power to require a bank or banking group to } \\
\text { strengthen them. }\end{array}$ \\
\hline & $\begin{array}{l}\text { BI regulations on risk management processes in banks require non-complex banks to } \\
\text { establish risk management policies and procedures for at least credit risk, market risk, } \\
\text { operational risk, and liquidity risk, while complex banking organizations must additionally } \\
\text { consider other material risks, including, legal, reputational, strategic, and compliance risks. } \\
\text { Banks are also required to perform quarterly risk profile self-assessments of their solo and } \\
\text { consolidated risk management practices and provide them to BI. The supervisory } \\
\text { framework includes vetting of these risk profile self-assessments, as a part of the off-site } \\
\text { process, and pursuing selected aspects with banks for improvement. The on-site process } \\
\text { provides for verification of these off-site assessments. }\end{array}$ \\
\hline & Please see description under EC 2 also. \\
\hline & $\begin{array}{l}\text { Essential Criterion 2: The supervisor confirms that banks and banking groups have } \\
\text { appropriate risk management strategies that have been approved by the Board. The }\end{array}$ \\
\hline
\end{tabular}


supervisor also confirms that the Board ensures that policies and processes for risk-taking are developed, appropriate limits are established, and senior management takes the steps necessary to monitor and control all material risks consistent with the approved strategies.

Implementation of effective risk management, as outlined in the above regulations, includes (i) the establishment of an independent risk-management unit and the establishment of a Board level risk management committee; (ii) effective oversight by BoD and $\mathrm{BoC}$ in (a) formulating comprehensive written risk management policies and strategies, which includes risk methodology, risk tolerance, risk limits, contingency plans, and control methods; and (b) overseeing and implementing the specified risk management policies and strategies within the bank; (iii) adequacy of policies and procedures as well as limit setting; (iv) adequacy of the processes for identification, measurement, monitoring, and control of risk, and of the management information system; and (v) effective internal control functions. The policies and procedures in place also must be approved and evaluated by the BoC, and must be commensurate with the banks' business, purpose, size, and complexity.

The regulatory requirements with regard to risk management under $\mathrm{BI}$ regulations are used as a basis for supervisors to assess risk management processes conducted by banks and banking groups. Supervisors conduct on-site supervision at least once a year to ensure that the policies and procedures have been properly implemented by banks in their business activities. If deemed necessary, the supervisors may directly conduct examinations of bank subsidiaries to ensure the effective implementation of consolidated risk management. The prevailing condition, possible future developments, as well as problems arising from the risk management processes of bank's subsidiaries, are factors that feed into the assessment of banks' risk management on a consolidated basis.

As part of ongoing supervision, supervisors review the bank's overall risk profile on a quarterly basis, taking into account the bank's self-assessment of its solo and consolidated risk profile, relevant off-site reports, and on-site examination findings.

Essential Criterion 3: The supervisor determines that risk management strategies, policies, processes and limits are properly documented, reviewed and updated, communicated within the bank and banking group, and adhered to in practice. The supervisor determines that exceptions to established policies, processes and limits receive the prompt attention of and authorization by the appropriate level of management and the Board where necessary.

Please see description under EC 2.

Essential Criterion 4: The supervisor determines that senior management and the Board understand the nature and level of risk being taken by the bank and how this risk relates to adequate capital levels. The supervisor also determines that senior management ensures that the risk management policies and processes are appropriate in the light of the bank's risk profile and business plan and that they are implemented effectively. This includes a requirement that senior management regularly reviews and understands the implications (and limitations) of the risk management information that it receives. The same requirement applies to the Board in relation to risk management information presented to it in a format suitable for Board oversight.

Please see description under EC 2.

While supervisors would be able to determine that senior management and the Board understand the nature and level of risk being taken by the bank, they are not able to determine that senior management and the BoC understand how the risk assumed by the bank relates to an adequate capital level. This arises because of the absence of robust internal capital methodologies in banks and the absence of a regulatory methodology for 
establishing the capital requirements for various risks.

Essential Criterion 5: The supervisor determines that banks have an internal process for assessing their overall capital adequacy in relation to their risk profile, and reviews and evaluates banks' internal capital adequacy assessments and strategies. The nature of the specific methodology used for this assessment will depend on the size, complexity and business strategy of a bank. Non-complex banks may opt for a more qualitative approach to capital planning.

Banks in Indonesia are in the process of developing internal methodologies for assessing their overall capital adequacy in relation to their risk profile. A few banks have developed internal models for measuring market risks. The efforts to link risks to capital levels are yet to come to fruition even in these selected banks, and can be seen as a work in progress. In most banks, there is no internal capital adequacy assessment process. Banks in Indonesia have a capital adequacy level that is well above the regulatory minimum. The driving force for the higher capital level in banks does not appear to be risk driven but seems to be the Bl's minimum absolute capital requirement of IDR 100 billion and its advice (suasion) to the top 14 banks to maintain a higher capital adequacy of at least 12 percent.

Essential Criterion 6: Where banks and banking groups use models to measure components of risk, the supervisor determines that banks perform periodic and independent validation and testing of the models and systems.

Banks in Indonesia are increasingly using internal models for measuring, monitoring, and managing their market risks. It is observed that even some of the large banks lack appropriate methodologies for validating the models they use. In one large bank, the model in use has a core component and the bank is unaware of the details of its operation.

Essential Criterion 7: The supervisor determines that banks and banking groups have adequate information systems for measuring, assessing and reporting on the size, composition and quality of exposures. It is satisfied that these reports are provided on a timely basis to the Board or senior management and reflect the bank's risk profile and capital needs.

Please see description under EC 2, 4 and 5

Essential Criterion 8: The supervisor determines that banks have policies and processes in place to ensure that new products and major risk management initiatives are approved by the Board or a specific committee of the Board.

$\mathrm{BI}$ regulations require banks to institute these policies and processes. Compliance is assessed through off-site and on-site supervision.

Essential Criterion 9: The supervisor determines that banks and banking groups have risk evaluation, monitoring, and control or mitigation functions with duties clearly segregated from risk-taking functions in the bank, and which report on risk exposures directly to senior management and the Board.

Please see description under EC 1 and 2

Essential Criterion 10: The supervisor issues standards related to, in particular, credit 


\begin{tabular}{|c|c|}
\hline & $\begin{array}{l}\text { risk, market risk, liquidity risk, interest rate risk in the banking book and operational risk. } \\
\mathrm{BI} \text { regulations on risk management prescribe the various elements for the management of } \\
\text { credit, market, liquidity, operational, legal, strategic, reputational, and compliance risk. The } \\
\mathrm{BI} \text { is yet to issue regulations on the management of interest rate risk in the banking book. }\end{array}$ \\
\hline Assessment & Largely Compliant \\
\hline Comments & $\begin{array}{l}\text { Indonesian banks largely lack internal methodologies for assessing their overall capital } \\
\text { adequacy in relation to their risk profile, and there is inadequate focus on and perhaps } \\
\text { capacity to validate internal models. BI is yet to issue regulations on the management of } \\
\text { interest rate risk in the banking book. As the Indonesian banking system is moving to } \\
\text { Basel II soon, these aspects gain greater importance. BI needs to issue appropriate } \\
\text { regulations as well as guidelines to banks on these aspects and also improve its } \\
\text { supervisory capacity to determine that these elements are implemented meaningfully in } \\
\text { banks and effectively practiced. } \\
\text { The recent experience of the banking system in regard to the sale of certain types of forex } \\
\text { derivatives shows that commercial banks had sold forex derivatives to customers without } \\
\text { verifying their underlying risk exposure and the inherent risk to themselves in those } \\
\text { transactions. This clearly demonstrates that the quality of risk management systems has } \\
\text { serious shortcomings. Bl supervisors were able to identify the lack of appropriate risk } \\
\text { management systems in this area in banks after defaults materialized. The lack of } \\
\text { effective suitability and appropriateness requirements in banks also became evident after } \\
\text { the turn of events. These bring to the fore weaknesses in the risk management systems in } \\
\text { banks and their supervision. }\end{array}$ \\
\hline Principle 8 & $\begin{array}{l}\text { Credit risk. Supervisors must be satisfied that banks have a credit risk management } \\
\text { process that takes into account the risk profile of the institution, with prudent policies and } \\
\text { processes to identify, measure, monitor and control credit risk (including counterparty } \\
\text { risk). This would include the granting of loans and making of investments, the evaluation } \\
\text { of the quality of such loans and investments, and the ongoing management of the loan } \\
\text { and investment portfolios. }\end{array}$ \\
\hline Description & $\begin{array}{l}\text { Essential Criterion 1: The supervisor determines, and periodically confirms, that a bank's } \\
\text { Board approves, and periodically reviews, the credit risk management strategy and } \\
\text { significant policies and processes for assuming, identifying, measuring, controlling and } \\
\text { reporting on credit risk (including counterparty risk). The supervisor also determines, and } \\
\text { periodically confirms, that senior management implements the credit risk strategy } \\
\text { approved by the Board and develops the aforementioned policies and processes. } \\
\text { BI regulations require banks to effectively manage risks arising from credit activities } \\
\text { (loans, treasury, investment, and trade financing). This includes establishing policies and } \\
\text { developing procedures to identify, measure, monitor, and control credit risk. Regulations } \\
\text { also emphasize the importance of Board involvement in the process, explicitly noting that } \\
\text { the Board is obliged to approve, review, and ensure effective implementation of the } \\
\text { policies and procedures. They specify, in greater detail, the minimum standard of credit } \\
\text { risk management to be implemented by commercial banks. } \\
\text { Supervisors conduct an off-site analysis and review of bank's credit risk profile using the } \\
\text { risk profile rating system and CAMELS. Some of the aspects included in these } \\
\text { assessments are } \\
\text { - banks' overall policies, procedures, and limits on the credit approval process; } \\
\text { - management's oversight of credit risk policies and procedures; } \\
\text { - the procedures in place to identify, measure, and monitor credit risks; }\end{array}$ \\
\hline
\end{tabular}


- banks' credit risk management information system.

Parameters used to assess the level of credit risk for bank's risk profile are, among others, NPLs, compliance with exposure limits, collateral, and credit growth. These aspects are also subject to review by the supervisor through on-site examination. The depth and breadth of the review and resources allocated to the credit risk on-site examination function are based on the perceived level of credit risk and risk controls, and on the supervisor's ongoing risk profile assessments. Through on-site examination, supervisors are able to verify and validate information submitted, as well as banks' compliance with $\mathrm{BI}$ and internal regulations related to credit risk. Supervisors have full access to all information related to, and individuals responsible for, the credit and investment portfolios.

While conducting examinations supervisors may access banks' subsidiaries when deemed necessary.

Essential Criterion 2 : The supervisor requires, and periodically confirms, that such policies and processes establish an appropriate and properly controlled credit risk environment, including:

- a well documented strategy and sound policies and processes for assuming credit risk;

- well defined criteria and policies and processes for approving new exposures as well as renewing and refinancing existing exposures, identifying the appropriate approval authority for the size and complexity of the exposures;

- effective credit administration policies and processes, including continued analysis of a borrower's ability and willingness to repay under the terms of the debt, monitoring of documentation, legal covenants, contractual requirements and collateral, and a classification system that is consistent with the nature, size and complexity of the bank's activities or, at the least, with the asset grading system prescribed by the supervisor;

- comprehensive policies and processes for reporting exposures on an ongoing basis;

- comprehensive policies and processes for identifying problem assets; and

- prudent lending controls and limits, including policies and processes for monitoring exposures in relation to limits, approvals and exceptions to limits.

$\mathrm{BI}$ regulations require banks to put in place Board approved policies and strategies that are consistent with the bank's risk tolerance, take account of economic cycles, and are designed to be flexible to meet the bank's long-term needs. The bank's BoD is responsible for implementing the credit risk strategy and policy and for developing the procedures for identification, measurement, monitoring, and control of credit risk. The policies and procedures are required to be capable of supporting sound lending standards, monitoring and controlling credit risk, and identifying and dealing with problem loans. Banks are required to adopt an appropriate information system and procedures to monitor the condition of debtors or counterparties in all credit portfolios. Such monitoring is required to be undertaken on a regular and ongoing basis in relation to the established risk limits, including collectability. Banks are required, at a minimum, to establish an asset grading system based on BI regulatory definitions of "current", "special mention", "substandard", "doubtful", and "loss". In practice, some larger banks have more refined and comprehensive internal credit grading systems that are ultimately mapped to Bl's regulatory definitions.

Banks' compliance with the various elements of BI regulations are verified at three levels at the level of the internal audit, at the level of the compliance function, and at the time of Bl's off-site assessments and on-site examination. Exceptions, if any, are pursued for 


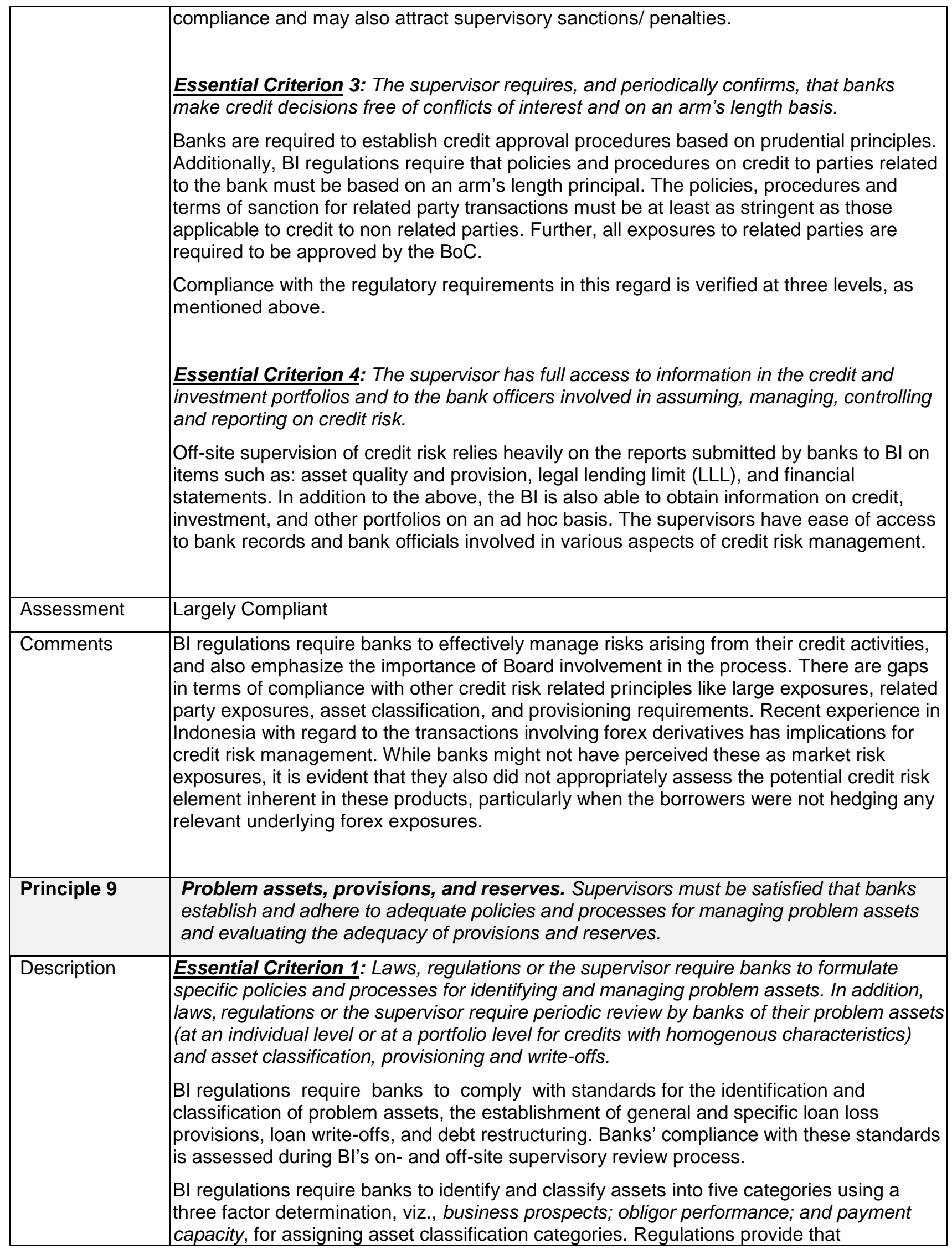


restructured debt shall be classified no higher than substandard for loans that were classified in more severe categories prior to the debt restructuring. All earning and nonearning assets (other than government securities and BI bonds (SBIs)) including placements, securities, loans, derivatives (positive MTM value), equity participations, foreclosed collateral, abandoned property, and off-balance sheet items, are subject to asset classification. Banks are required to review the asset classification status and the provisions held against such assets at least every three months.

Essential Criterion 2: The supervisor confirms the adequacy of the classification and provisioning policies and processes of a bank and their implementation; the reviews supporting this opinion may be conducted by external experts.

$\mathrm{BI}$ regulations prescribe, in adequate detail, the methods for classification and provisioning of assets, which are:

1. Earning Asset Classification based on promptness of payment

- Earning assets which are deemed to be small in terms of amount/exposures may be classified only based on the promptness of the payment of principal/and or interest. Banks that meet certain norms relating to capital adequacy, the risk control system, and rating may also classify loans to micro, small, and medium enterprises based on promptness of payment.

2. Earning Asset Classification based on the "Three Pillars"

- All other earning assets must be classified based on an assessment of what $\mathrm{BI}$ terms as "the 3 pillars", they are: business prospects; obligor performance; and payment capacity;

Based on analysis of the above factors, earning assets are categorized into 5 different classifications; (i) current, (ii) special mentioned, (iii) sub-standard, (iv) doubtful, and (v) loss. Specific delinquency periods, as well as percentages of provisioning assigned for each of the 5 different asset classifications, are as follows:

\begin{tabular}{|l|l|l|}
\hline Asset classification & Delinquency period & $\begin{array}{l}\text { Provisioning } \\
\text { requirement }\end{array}$ \\
\hline Current & - & $1 \%$ \\
\hline Special mentioned & 1 to 90 days & $5 \%$ \\
\hline Substandard & $>90$ to 120 days & $15 \%$ \\
\hline Doubtful & $>120$ to 180 days & $50 \%$ \\
\hline Loss & $>180$ days & $100 \%$ \\
\hline
\end{tabular}

Provisions are maintained by banks, for all categories of asset classification, after netting the value of collateral from the gross amounts outstanding. Collateral value is subject to haircuts prescribed in $\mathrm{BI}$ regulations, which are dependent upon the type of collateral and time since the last valuation. Given the weaknesses in collateral and creditor rights enforcement frameworks in Indonesia and the consequent low recovery rate (please refer to paragraph 18), even in respect of secured exposures, the regulatory provisioning requirements are seen to be on the low side.

Till 2005, classification of the different earning assets of an obligor in a bank was required to be applied uniformly based on the lowest grade classification (one obligor concept). In 2005, Bl extended the uniform asset classification requirement across banks. Hence the facilities belonging to an obligor were required to be classified uniformly within the entire banking system based on the lowest grade classification. Since 2005, banks have also been required to classify non earning assets (such as foreclosed assets, suspense 
accounts, and abandoned assets) and hold provisions for these non earning assets. Regulations exempt all exposures up to IDR 10 billion (USD 1 million) in each bank from the requirement of uniform asset classification, and such exemption also applies if assets are classified on the basis of different assessment factors.

All restructured debt requires a calculation of net present value (NPV) loss (using the loan's original effective interest rate) and provisioning at the time of restructuring. $\mathrm{BI}$ regulations stipulate that restructured debt shall be classified no higher than substandard for credit that was classified in a more severe category prior to debt restructuring, allowing immediate upgrading of restructured NPLs.

The regulations in place for asset classification of temporary equity participation (representing conversion of debt to equity at the time of restructuring) and foreclosed collateral are different from those applicable to credit, making it possible for banks to classify portions of NPLs as 'current' immediately after restructuring or on foreclosure. The difference is evident from the table below.

\begin{tabular}{|l|l|l|l|}
\hline Asset classification & $\begin{array}{l}\text { Credit } \\
\text { (Delinquency } \\
\text { period) }\end{array}$ & $\begin{array}{l}\text { Temporary } \\
\text { equity (period } \\
\text { for which held) }\end{array}$ & $\begin{array}{l}\text { Foreclosed } \\
\text { collateral (period } \\
\text { for which held) }\end{array}$ \\
\hline Current & - & Up to one year & Up to one year \\
\hline Special mention & 1 to 90 days & -- & -- \\
\hline Substandard & $>90$ to 120 days & 1 to 4 years & 1 to 3 years \\
\hline Doubtful & $>120$ to 180 days & 4 to 5 years & 3 to 5 years \\
\hline Loss & $>180$ days & $\begin{array}{l}\text { If not withdrawn } \\
\text { even though } \\
\text { debtor company } \\
\text { has not posted } \\
\text { cumulative profits }\end{array}$ & More than 5 years \\
\hline
\end{tabular}

The asset classification norms applicable to exposures covered by government guarantees, Gol bonds, BI bonds, prime bank guarantees, MDA guarantees (referred to as cash collateral in regulations) do not require these exposures to be classified below 'current' as banks are required to submit the claim for encashment no later than seven days after the event of default, i.e., even when there are payments in arrears for 97 days.

On a monthly and quarterly (off-site) basis, BI receives a detailed list of the bank's asset classifications, associated provisions, and restructured loans through various regulatory reports. Supervisors are thus equipped to verify the accuracy of asset classification, and test the adequacy of reported provisions and reasonableness of debt restructuring practices.

Essential Criterion 3: The system for classification and provisioning takes into account off-balance sheet exposures.

Please see description under EC 1. 
Essential Criterion 4: The supervisor determines that banks have appropriate policies and processes to ensure that provisions and write-offs reflect realistic repayment and recovery expectations.

Bl's minimum provisioning requirements require banks to apply minimum loss percentages based on the severity of the asset classification category, after deduction of eligible collateral. As collateral valuations can be inherently imprecise in nature, $\mathrm{BI}$ has in place haircut rules, as well as requirements for independence and appraisal frequency, to prevent an overestimation of collateral value for purposes of loan loss provisioning (subject to various haircuts between 30-70 percent depending on type and collateral value, as well as the time interval since the latest appraisal).

$\mathrm{BI}$ regulations state that these are minimum requirements, and that banks are encouraged to develop more robust means to assess their loan loss provisioning adequacy. Adequacy of these provisions is verified off-site on the basis of the details reported by banks and is also subject to on-site assessments.

It is observed that banks tend to maintain provisions for NPLs close to the regulatory requirement, which suggests that banks are generally guided by the minimum regulatory requirements. At the system level, provisions for NPLs held by banks were about 60 percent of NPLs at end-September 2009.

Please see description under EC 2 also.

Essential Criterion 5: The supervisor determines that banks have appropriate policies and processes, and organizational resources for the early identification of deteriorating assets, for ongoing oversight of problem assets, and for collecting on past due obligations.

The regulations require banks to categorize all delinquent accounts with delinquencies ranging from 1 to 90 days as 'special mention' accounts (subject to the exemptions specified above). Once the accounts are classified in this category they attract a higher level of provisioning. Banks generally focus more attention on the accounts in this category in view of their inherent credit quality weakness. Banks pursue recovery or restructuring options in respect of these accounts with a view to preventing them from slipping into the non performing category. With regard to ongoing oversight and collection of past due loans, BI regulations require banks to have an independent unit responsible for identification and monitoring as well as resolving problem loans (special asset management unit and credit risk review function) in a timely manner. Compliance is verified during on-site visits.

Essential Criterion 6: The supervisor is informed on a periodic basis, and in relevant detail, or has access to information concerning the classification of credits and assets and provisioning.

Please see description under EC 2.

Essential Criteria 7: The supervisor has the power to require a bank to increase its levels of provisions and reserves and/or overall financial strength if it deems the level of problem assets to be of concern.

Please see description under EC 8

Essential Criterion 8 : The supervisor assesses whether the classification of the credits 
and assets and the provisioning is adequate for prudential purposes. If provisions are deemed to be inadequate, the supervisor has the power to require additional provisions or to impose other remedial measures.

Please see description under EC 1 to 5.

Based on the on-site assessment, BI may require banks to modify their reported volume of adversely classified assets; require an increase in provisions; and / or take any other appropriate actions related to weak credit risk management practices, including a downgrade in the relevant CAMELS rating. Results of the examinations are reported to the banks' BoC and BoD, either through a meeting or through a supervisory letter.

Essential Criterion 9: The supervisor requires banks to have appropriate mechanisms in place for periodically assessing the value of risk mitigants, including guarantees and collateral. The valuation of collateral is required to reflect the net realisable value.

Please see description under EC 4

Essential Criterion 10: Laws, regulations or the supervisor establish criteria for assets to be identified as impaired, e.g. loans are identified as impaired when there is reason to believe that all amounts due (including principal and interest) will not be collected in accordance with the contractual terms of the loan agreement.

Please see description under EC 2.

$\mathrm{BI}$ has relaxed certain aspects of its asset quality regulation in order to encourage lending and economic growth. Amendments to the requirement include changes in the implementation of the uniform asset classification requirement, as well as the asset quality assessment process.

- Bank Indonesia Regulation No 9/6/PBI/2007 relaxed the one obligor concept by increasing the threshold of credit amount for which banks are required to apply the one obligor concept, and adds a clause which enables banks to switch from the one obligor concept when certain requirements are met.

- Bank Indonesia Regulation No 11/2/PBI/2009 states that certain banks that have demonstrated "strong" credit risk management are eligible to apply the delinquency only criteria for credit exposures up to IDR 20 billion (USD 2 million) (specifically for small and medium enterprises meeting certain criteria), while previously the delinquency only criteria was applied specifically for exposures up to IDR 500 million (USD 0.05 million).

Essential Criterion 11: The supervisor determines that the Board receives timely and appropriate information on the condition of the bank's asset portfolio, including classification of credits, the level of provisioning and major problem assets.

During on-site examinations, the supervisors are able to evaluate the appropriateness of credit quality information provided to the bank's Board of Commissioners.

Essential Criterion 12: The supervisor requires that valuation, classification and provisioning for large exposures are conducted on an individual item basis.

$\mathrm{BI}$ regulations require banks to apply classification and provisioning requirements on each credit exposure, irrespective of the size of the exposure, once they have become 


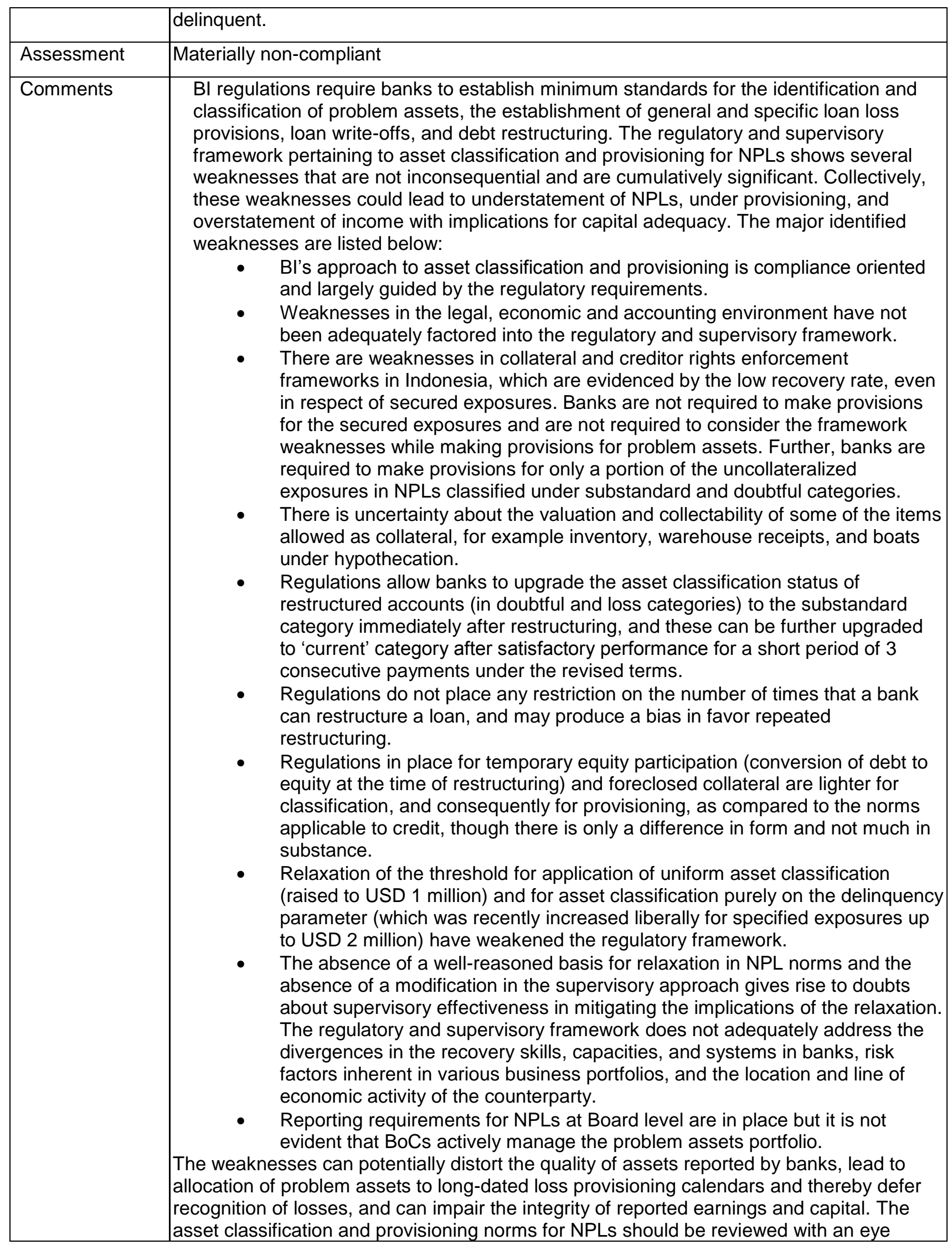




\begin{tabular}{|c|c|}
\hline & $\begin{array}{l}\text { toward ensuring that the banking system is adequately identifying and managing problem } \\
\text { assets, including provisioning, in line with newly emerging risks. The provisioning matrix } \\
\text { requires frequent review to make sure it is aligned with actual system experience. } \\
\text { Regulations may need to be enhanced to ensure that the BoC is actively managing } \\
\text { problem assets. } \\
\text { BI may also consider requiring a longer time frame (rather than the current requirement of } \\
\text { three payments) that is prudent to establish true improvement in asset quality, before } \\
\text { banks are permitted to upgrade the asset classification status of restructured accounts to } \\
\text { the 'current' category. }\end{array}$ \\
\hline Principle 10 & $\begin{array}{l}\text { Large exposure limits : Supervisors must be satisfied that banks have policies and } \\
\text { processes that enable management to identify and manage concentrations within the } \\
\text { portfolio, and supervisors must set prudential limits to restrict bank exposures to single } \\
\text { counterparties or groups of connected counterparties. }\end{array}$ \\
\hline \multirow[t]{5}{*}{ Description } & $\begin{array}{l}\text { Essential Criterion 1: Laws or regulations explicitly define, or the supervisor has the } \\
\text { power to define, a "group of connected counterparties" to reflect actual risk exposure. The } \\
\text { supervisor may exercise discretion in applying this definition on a case by case basis. } \\
\text { Bl regulations (on legal lending limits - (LLL)) prescribe the ground rules for identifying a } \\
\text { borrower group. A borrower shall be classified as a member of a borrower group if control } \\
\text { exists between the borrower and another borrower by means of ownership, management, } \\
\text { and / or financial ties. Supervisors have sufficient discretion to exercise judgment in } \\
\text { determining groups of connected counterparties, based on institution specific } \\
\text { circumstances. }\end{array}$ \\
\hline & $\begin{array}{l}\text { Essential Criterion 2: Laws, regulations or the supervisor set prudent limits on large } \\
\text { exposures to a single counterparty or a group of connected counterparties. "Exposures" } \\
\text { include all claims and transactions, on-balance sheet as well as off-balance sheet. The } \\
\text { supervisor confirms that senior management monitors these limits and that they are not } \\
\text { exceeded on a solo or consolidated basis. }\end{array}$ \\
\hline & $\begin{array}{l}\text { The BI regulation on the legal lending limit defines groups of connected counterparties, } \\
\text { and sets prudential limits on bank exposures to a single counterparty and a group of } \\
\text { connected counterparties at } 20 \text { percent and } 25 \text { percent of total capital, respectively. In } \\
\text { respect of state owned banks, BI regulations allow these banks to assume a higher } \\
\text { exposure up to } 30 \text { percent of total capital for SOEs, for development purposes. The } \\
\text { regulations have explicitly excluded the treatment of all SOEs as a group. }\end{array}$ \\
\hline & $\begin{array}{l}\text { Regulation defines exposures to include both fund based and non-fund based exposures, } \\
\text { including potential future exposures under derivative contracts. However, the regulations } \\
\text { explicitly exclude undrawn balances on sanctioned loans. Further, Bl regulations allow } \\
\text { certain deductions from exposure. These deductions, among others, include (a) exposures } \\
\text { covered by Government of Indonesia guarantees that meet specified norms (Art } 27,29 \text { ), } \\
\text { (b) cash collaterals in the form of demand/ savings/ time/ guarantee deposits, gold, Govt. } \\
\text { of Indonesia and BI bonds meeting specified norms (Art 27), (c) interbank placements } \\
\text { within Indonesia up to } 14 \text { days (Art 30), (d) negotiation of export bills under usance LC } \\
\text { accepted by a prime bank (Art 32), (e) exposures covered by a prime bank guarantee that } \\
\text { meets the specified norms (Art 33), (f) placements at prime banks (Art 34), (g) exposures } \\
\text { guaranteed by MDA (Art 35), and (h) temporary equity participation as a part of the } \\
\text { restructuring package. }\end{array}$ \\
\hline & $\begin{array}{l}\text { Essential Criterion 3: The supervisor determines that a bank's management information } \\
\text { systems identify and aggregate on a timely basis exposure to individual counterparties and }\end{array}$ \\
\hline
\end{tabular}




\begin{tabular}{|c|c|}
\hline & groups of connected counterparties. \\
\hline & $\begin{array}{l}\text { In terms of } \mathrm{BI} \text { regulations, banks are required to have formal written policies and } \\
\text { procedures in place to manage large exposures in particular, and risk concentration in } \\
\text { general. These policies and procedures must be approved by the BoC and the BoD, and } \\
\text { include information system development to enable management to identify credit } \\
\text { concentrations in a timely manner. }\end{array}$ \\
\hline & $\begin{array}{l}\text { BI requires banks to strictly comply with the LLL and violations or excesses attract } \\
\text { penalties that include monetary penalties, written warning, disqualification of management, } \\
\text { employees and shareholders from a fit and proper perspective, freezing of certain } \\
\text { business activities, prohibition from participation in clearing activities, and criminal } \\
\text { penalties. Breaches tend to occur on account of movement in exchange rates, mergers } \\
\text { and acquisitions among borrowers, drop in capital levels, etc (market developments). } \\
\text { Banks are required to submit action plans for ensuring compliance with the LLL. (Please } \\
\text { see description under EC5 also) }\end{array}$ \\
\hline & $\begin{array}{l}\text { Essential Criterion 4: The supervisor confirms that a bank's risk management policies } \\
\text { and processes establish thresholds for acceptable concentrations of credit and require that } \\
\text { all material concentrations be reviewed and reported periodically to the Board. }\end{array}$ \\
\hline & Please see description under EC5. \\
\hline & $\begin{array}{l}\text { Essential Criterion 5: The supervisor regularly obtains information that enables } \\
\text { concentrations within a bank's portfolio, including sectoral, geographical and currency } \\
\text { exposures, to be reviewed. The supervisor has the power to require banks to take } \\
\text { remedial actions in cases where concentrations appear to present significant risks. }\end{array}$ \\
\hline & $\begin{array}{l}\text { BI regularly assesses banks' large exposures and industry concentrations, through the on- } \\
\text { and off-site supervisory review process. Off-site supervision utilizes monthly reports } \\
\text { submitted by banks, which contain information such as loans, placements, securities, etc. } \\
\text { Banks are also required to submit the details of their } 50 \text { largest debtors on a quarterly } \\
\text { basis as part of the regulatory reporting requirements. Off-site analyses help supervisors } \\
\text { to aggregate the amount of exposures by a specific criterion, such as currency, } \\
\text { geographical region, product, industry type, maturity, etc. that enables identification of } \\
\text { concentrations. The results of off-site analyses serve as inputs in determining key areas } \\
\text { with respect to large exposures for the on-site examination. Supervisors are able to } \\
\text { identify major individual borrowers and portfolio concentrations, and take appropriate } \\
\text { actions as needed. }\end{array}$ \\
\hline & $\begin{array}{l}\text { Bl's on-site examination includes test checking of the accuracy of data reported in the off- } \\
\text { site returns and may also include an examination of IT systems to ensure the capability } \\
\text { and accuracy in the data aggregation and disaggregation process. Banks' internal audit } \\
\text { function, the external auditors, and the compliance function are also required to assess the } \\
\text { integrity of supervisory reporting. }\end{array}$ \\
\hline Assessment & Largely Compliant \\
\hline Comments & $\begin{array}{l}\text { There are shortcomings in the definition of exposure, as undrawn balances on sanctioned } \\
\text { loans and temporary equity participation as a part of the restructuring package are } \\
\text { excluded while computing exposure. Further, from the perspective of risk concentration, it } \\
\text { would be relevant for } \mathrm{BI} \text { to consider (a) gross exposures without any deductions, and (b) } \\
\text { SOEs as a group. } \\
\text { It would be useful for the } \mathrm{BI} \text { and the banks to monitor concentrations with reference to all } \\
\text { exposures that exceed a threshold level that is below the single counterparty regulatory } \\
\text { limit - say } 10 \text { percent of total capital (to be defined as 'large exposures'). The BI could also }\end{array}$ \\
\hline
\end{tabular}




\begin{tabular}{|c|c|}
\hline & $\begin{array}{l}\text { consider requiring banks to fix an aggregate limit for 'large exposures' at say } 6 \text { to } 8 \text { times } \\
\text { total capital. The aggregate limits may vary from bank to bank and will be determined by } \\
\text { their individual risk appetites and risk management capabilities. }\end{array}$ \\
\hline & $\begin{array}{l}\text { BI should develop a broader regulation on management of credit risk concentrations in the } \\
\text { context of Basel II, including issues regarding, for example, credit concentration within a } \\
\text { specific industry, geographic region, and currency, which may not be addressed } \\
\text { adequately at present. These regulations could also focus on appropriate information } \\
\text { systems in banks and off-site reports to BI. }\end{array}$ \\
\hline & $\begin{array}{l}\text { BI regulations allow banks a time frame ranging from } 9 \text { months to } 18 \text { months for bringing } \\
\text { the exposures within the LLL if the breach has occurred due to market developments } \\
\text { (movement in forex rates, mergers and acquisitions, drop in capital levels of banks, etc.) } \\
\text { with scope for agreeing on a different time frame with BI approval. It might be useful to } \\
\text { consider specifying a maximum time limit of say } 12 \text { months for compliance and in case the } \\
\text { banks are not able to comply with the LLL by that time, the BI could consider imposing } \\
\text { appropriate sanctions, including deduction from capital for capital adequacy purposes. It } \\
\text { would also be useful for the BI to review the concept of 'market developments' and make it } \\
\text { more restrictive to ensure a better credit risk management discipline in banks. }\end{array}$ \\
\hline Principle 11 & $\begin{array}{l}\text { Exposures to related parties. In order to prevent abuses arising from exposures (both } \\
\text { on-balance sheet and off-balance sheet) to related parties and to address conflict of } \\
\text { interest, supervisors must have in place requirements that banks extend exposures to } \\
\text { related companies and individuals on an arm's length basis; these exposures are } \\
\text { effectively monitored; appropriate steps are taken to control or mitigate the risks; and } \\
\text { write-offs of such exposures are made according to standard policies and processes. }\end{array}$ \\
\hline Description & $\begin{array}{l}\text { Essential Criterion 1: Laws or regulations explicitly provide, or the supervisor has the } \\
\text { power to provide, a comprehensive definition of "related parties". This should consider the } \\
\text { parties identified in the footnote to the Principle. The supervisor may exercise discretion in } \\
\text { applying this definition on a case by case basis. }\end{array}$ \\
\hline & $\begin{array}{l}\text { The definition and limits applicable to related parties are stipulated in BI regulations and } \\
\text { are applied both at solo and consolidated levels. Regulations provide a detailed definition } \\
\text { of related parties and exposure. It also prescribes a cap on aggregate exposure to all } \\
\text { related parties at no more than } 10 \text { percent of a bank's capital. In terms of these } \\
\text { regulations, SOEs are not considered as related parties of the state owned banks, as long } \\
\text { as the relationship arises on account of direct ownership by the Government of Indonesia. }\end{array}$ \\
\hline & $\begin{array}{l}\text { Currently, BI regulations do not explicitly address all transactions with related parties. For } \\
\text { example, acceptance of deposits from related parties and other non-credit transactions, } \\
\text { such as awarding of contracts, are not within the scope of the BI regulations on related } \\
\text { party exposures. This issue is generally, but not explicitly, addressed through the good } \\
\text { corporate governance (GCG) regulations, which require banks to implement prudent } \\
\text { policies to reduce the scope for any potential intervention by related parties that may } \\
\text { prove to be harmful to the bank (Article } 54 \text { of } \mathrm{BI} \text { regulation } 8 / 4 / \mathrm{PBI} / 2006 \text { ). }\end{array}$ \\
\hline & $\begin{array}{l}\text { Supervisors have sufficient discretion to exercise judgment in determining related parties, } \\
\text { based on institution specific circumstances. }\end{array}$ \\
\hline & $\begin{array}{l}\text { Essential Criterion 2: Laws, regulations or the supervisor require that exposures to } \\
\text { related parties may not be granted on more favourable terms (ie for credit assessment, } \\
\text { tenor, interest rates, amortisation schedules, requirement for collateral) than } \\
\text { corresponding exposures to non-related counterparties. }\end{array}$ \\
\hline & $\begin{array}{l}\mathrm{BI} \text { regulations stipulate that the processes, criteria, and controls for assuming exposures } \\
\text { on related parties and the terms of sanctions must be at least as stringent as the }\end{array}$ \\
\hline
\end{tabular}


procedures/underwriting standards for non related counterparties, and requires that any related party exposure is assumed only with the prior approval of the $\mathrm{BoC}$.

Essential Criterion 3: The supervisor requires that transactions with related parties and the write-off of related-party exposures exceeding specified amounts or otherwise posing special risks are subject to prior approval by the bank's Board. The supervisor requires that Board members with conflicts of interest are excluded from the approval process.

Banks are prohibited from assuming exposures on related parties without the approval of the BoC. Regulations require banks to pursue corrective measures, including but not limited to repayment within a period of 60 days after downgrading of related party exposures as NPLs, or proceed with debt restructuring. The regulations are silent with regard to write-offs of related party exposures.

BI regulations regarding good corporate governance (GCG) supplements the legal lending limit regulation in relation to related parties by stipulating various requirements such as,

- prohibition of board members from any personal gain besides remuneration,

- in the event of a conflict of interest, board members are required to disclose such information, and are prohibited from taking any actions that will cause a loss or decrease the bank's profit.

The regulations do not explicitly require the BoD or BoC members to abstain from participating in the discussions or decisions on matters in which they are interested or that involve conflict of interest.

Essential Criterion 4 : The supervisor requires that banks have policies and processes in place to prevent persons benefiting from the exposure and/or persons related to such a person from being part of the process of granting and managing the exposure.

Please see description under EC 3 regarding conflicts at board level.

Regulations do not explicitly require the exclusion of persons benefiting from the exposure and/or persons related to such persons from being part of the process of granting and managing the exposure.

Essential Criterion 5: Laws or regulations set, or the supervisor has the power to set on a general or case by case basis, limits for exposures to related parties, to deduct such exposures from capital when assessing capital adequacy, or to require collateralisation of such exposures. When limits are set on aggregate exposures to related parties those are at least as strict as those for single counterparties, or groups of connected counterparties.

$\mathrm{BI}$ regulations prescribe a cap on aggregate exposure to all related parties at 10 percent of the bank's capital. In terms of these regulations, SOEs are not considered as related parties of the state owned banks, as long as the relationship arises on account of direct ownership by the Government of Indonesia. The related party exposure limits are more stringent than the prudential exposure limits for single borrower and group borrower (please see Principle 10, EC 2 for details). BI monitors compliance with the related party exposure limits both through off-site and on-site supervision.

'Exposure' has been defined comprehensively in BI regulations and includes potential future exposures under derivative contracts. However, BI regulations allow certain exclusions and deductions, which include (1) undrawn balances on sanctioned loans, and (2) exposures that are (a) covered by Government of Indonesia guarantees that meet 


\begin{tabular}{|c|c|}
\hline & $\begin{array}{l}\text { specified norms (Art 27, 29), (b) cash collaterals in the form of demand/ savings/ time/ } \\
\text { guarantee deposits, gold, Govt. of Indonesia and BI bonds meeting specified norms (Art } \\
\text { 27), (c) guaranteed by prime banks and placements with prime banks, (d) interbank } \\
\text { placements within Indonesia up to } 14 \text { days (Art 30), (e) negotiation of export bills usance } \\
\text { LC accepted by a prime bank (Art 32), (f) exposures covered by a prime bank guarantee } \\
\text { that meets the specified norms (Art 33), (f) placements at prime banks (Art 34), (g) } \\
\text { guaranteed by MDA (Art 35), (h) temporary equity participation as a part of the } \\
\text { restructuring package. }\end{array}$ \\
\hline & $\begin{array}{l}\text { The definition of related party was amended in } 2006(8 / 13 / \mathrm{PBI} / 2006 \text {, Art } 40 \mathrm{~A} \text { to } 40 \mathrm{C}) \text { to } \\
\text { exclude certain counterparties who were earlier considered as a related party. }\end{array}$ \\
\hline & $\begin{array}{l}\text { The regulations and supervisory practices do not require banks to either deduct related } \\
\text { party exposures for capital adequacy purposes or collateralize these exposures. }\end{array}$ \\
\hline & $\begin{array}{l}\text { Essential Criterion } 6 \text { : The supervisor requires banks to have policies and processes to } \\
\text { identify individual exposures to related parties as well as the total amount of such } \\
\text { exposures, and to monitor and report on them through an independent credit review } \\
\text { process. The supervisor confirms that exceptions to policies, processes and limits are } \\
\text { reported to the appropriate level of senior management and, if necessary, to the Board, for } \\
\text { timely action. The supervisor also confirms that senior management monitors related party } \\
\text { transactions on an ongoing basis, and that the Board also provides oversight of these } \\
\text { transactions. }\end{array}$ \\
\hline & $\begin{array}{l}\text { In terms of BI regulations, banks are required to have formal written policies and } \\
\text { procedures as well as risk management systems with regard to exposures to related } \\
\text { parties, including an adequate information system that enables management to identify } \\
\text { concentration in exposures in a timely manner. Banks are prohibited from assuming } \\
\text { exposures on related parties without the approval of the BoC. Banks are conscious of the } \\
\text { need to strictly comply with the related party regulations including the need to comply with } \\
\text { the regulatory limit. }\end{array}$ \\
\hline & $\begin{array}{l}\text { The supervisory framework provides for an assessment of the management of related } \\
\text { party exposures through the off-site process, and a review thereof, during the annual on- } \\
\text { site examination process. }\end{array}$ \\
\hline & $\begin{array}{l}\text { Essential Criterion 7: The supervisor obtains and reviews information on aggregate } \\
\text { exposures to related parties. }\end{array}$ \\
\hline & $\begin{array}{l}\text { Banks are required to submit the LLL report (including the aggregate legal limit for related } \\
\text { parties) on a monthly basis. In the event that limits are breached, the bank is required to } \\
\text { submit an action plan and resolve the breach within a predetermined time limit. Breaches } \\
\text { of the regulatory limits attract penalties that include monetary penalties, written warning, } \\
\text { disqualification of management, employees and shareholders from a fit and proper } \\
\text { perspective, freezing of certain business activities, prohibition from participation in clearing } \\
\text { activities, and criminal penalties. }\end{array}$ \\
\hline & $\begin{array}{l}\text { The supervisory process is confined to monitoring of related party exposures net of the } \\
\text { exemptions and deductions, and compliance with the regulatory limit is verified with } \\
\text { reference to the net related party exposures. }\end{array}$ \\
\hline Assessment & Largely Compliant \\
\hline Comments & $\begin{array}{l}\text { As the prime focus of the principle is to prevent abuses arising from exposures to related } \\
\text { parties and to address conflicts of interest, it would be advisable for BI to (a) ensure that } \\
\text { all interested parties not only disclose their interests but also exclude themselves from the } \\
\text { process of granting, managing, and resolving related party exposures; and (b) review and }\end{array}$ \\
\hline
\end{tabular}




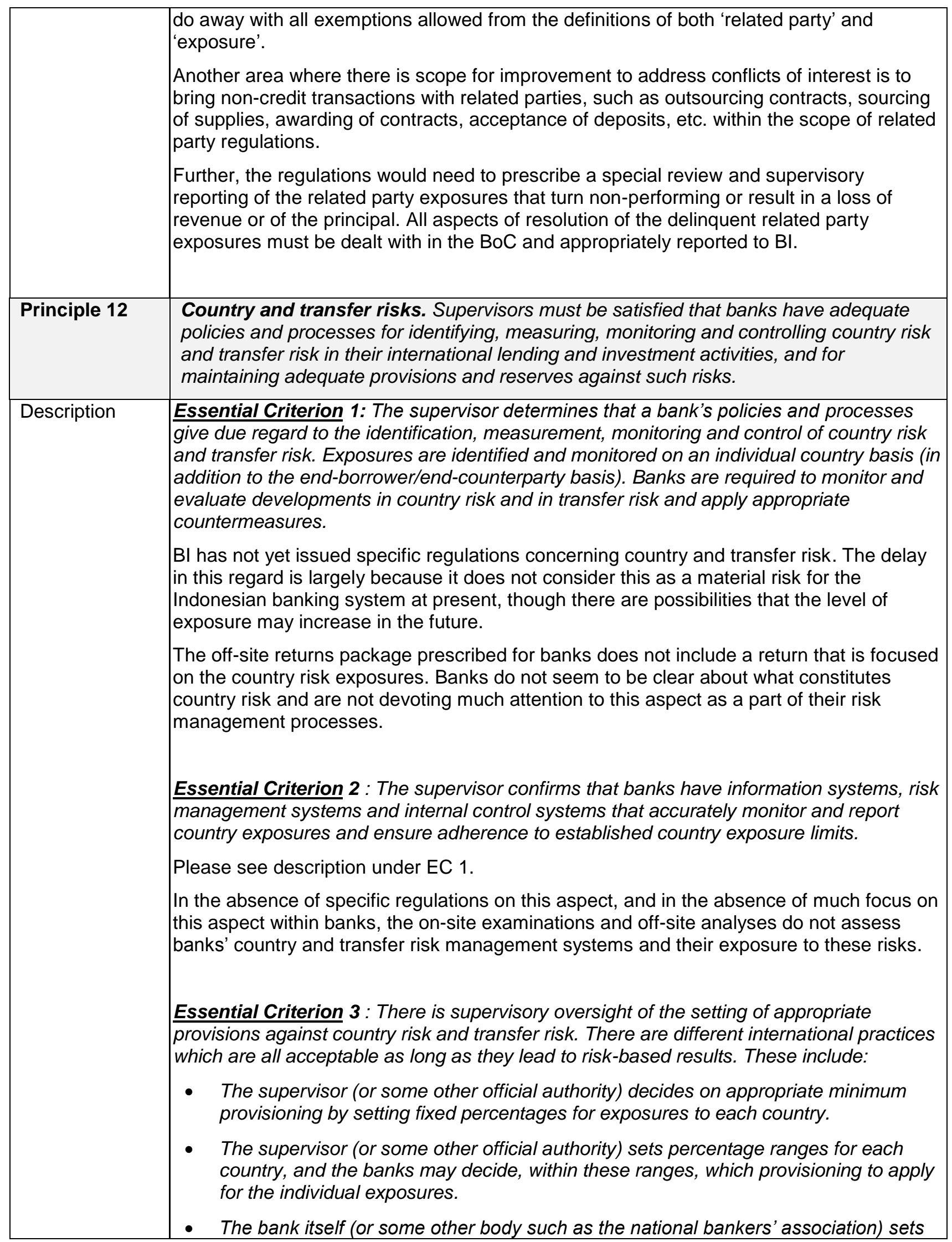




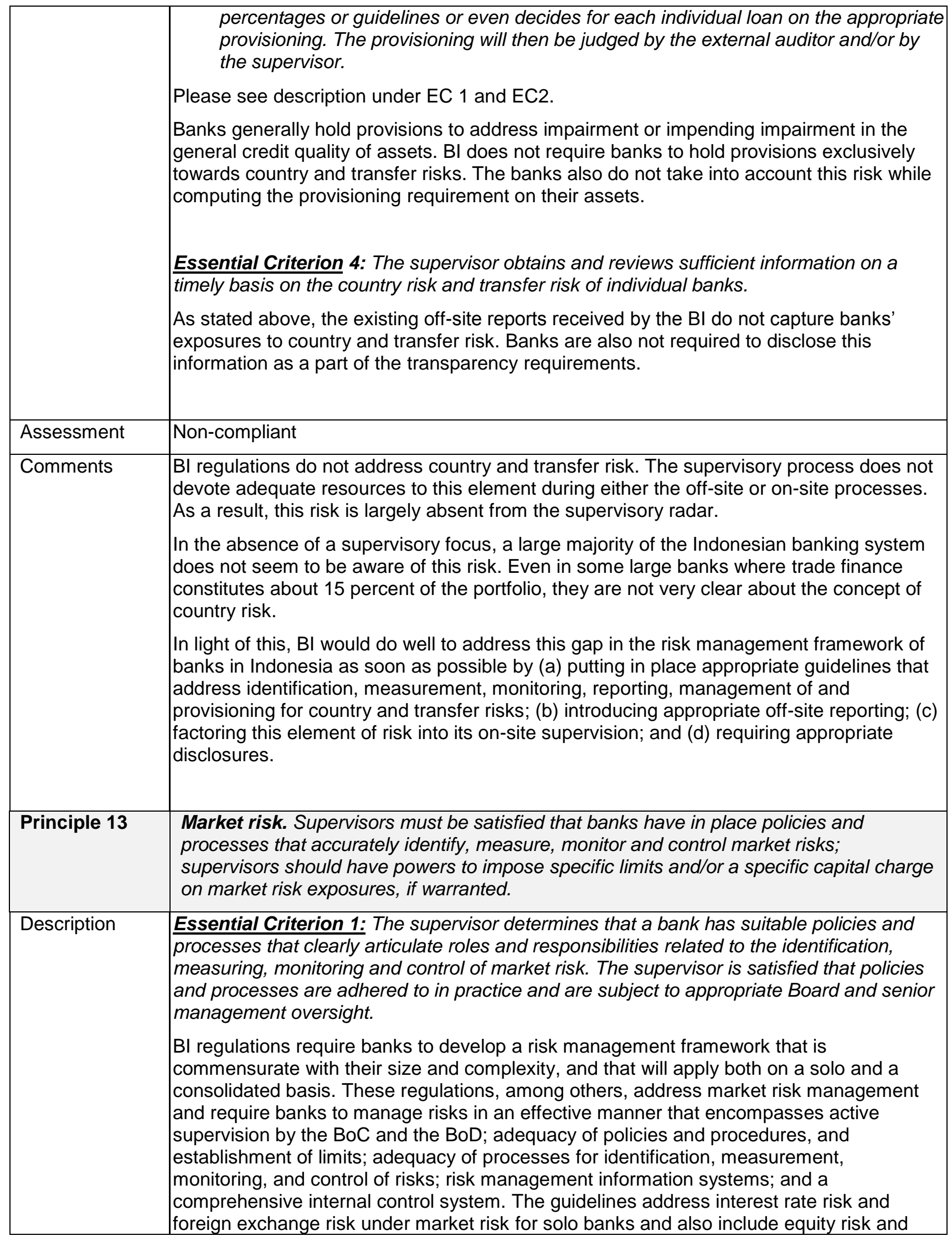


commodities risk for consolidated banks. BI regulations on internal control and compliance require banks to ensure adherence to the various aspects of the regulations, including those pertaining to risk management.

During the off-site review cycle, $\mathrm{BI}$ focuses primarily on risk monitoring by relying on several prudential and internally generated reports submitted by banks e.g. daily Net Open Position (NOP) report, monthly market risk capital charge, quarterly risk profile report, and any other additional reports if considered necessary. In addition, supervisors also make use of other sources of information such as Know Your Bank (KYB) material and the previous audit report.

Based on these inputs, together with the supervisors' institutional knowledge of the banks' market risk management practices, $\mathrm{BI}$ assigns quarterly "S" ratings using the CAMELS framework (focusing mainly on risk to capital from adverse movements in FX or interest rates); and a "market risk" rating in the risk profile assessments (which is a more qualitative assessment based on the bank's inherent level of market risk, together with the quality of its risk control systems). The result of the assessment determines the individual supervisory strategy and audit plan for market risk management in each bank.

Further, periodically, supervisors conduct on-site examinations for assessing banks' market risk management framework. On-site supervision, among others, includes several key areas, such as limit setting; valuation policies, procedures, and systems; and adherence to internal limits set by the banks' BoC/ BoD. Areas that are identified for improvement are agreed upon at the end of the supervisory exercise with the $\mathrm{BoC}$ and $\mathrm{BoD}$, and are followed up.

Essential Criterion 2: The supervisor determines that the bank has set market risk limits that are commensurate with the institution's size and complexity and that reflect all material market risks. Limits should be approved by the Board or senior management. The supervisor confirms that any limits (either internal or imposed by the supervisor) are adhered to.

Banks in Indonesia are required to comply with a regulatory limit on Net Open Position (NOP), which is capped at 20 percent of the bank's capital. BI has not prescribed limits for banks' interest rate risk. Regulations require banks to fix appropriate internal limits with the approval of their BoC/ BoD. Regulations require that only banks above a certain threshold need to maintain capital for market risks.

$\mathrm{BI}$ has established a team of market risk specialists within each supervision directorate, in order to support the needs of generalist supervisors. The main responsibility of market risk specialists is to help provide technical support during the on-site supervisory review of the complex market risk activities of banks - focusing on the trading book.

Please see description under EC 1 also.

Essential Criterion 3 : The supervisor is satisfied that there are systems and controls in place to ensure that all transactions are captured on a timely basis, and that the banks' marked to market positions are revalued frequently, using reliable and prudent market data (or, in the absence of market prices, internal or industry-accepted models). The supervisor requires banks to establish and maintain policies and processes for considering valuation adjustments/reserves for positions that otherwise cannot be prudently valued, including concentrated, less liquid, and stale positions.

Regulations require banks to mark-to-market their trading book exposures on a daily basis. The regulations also address the requirements where there may be a need for adjustments for positions that otherwise cannot be prudently valued, including where there are concentrated or less liquid or stale positions. Regulations require that the mark-to- 


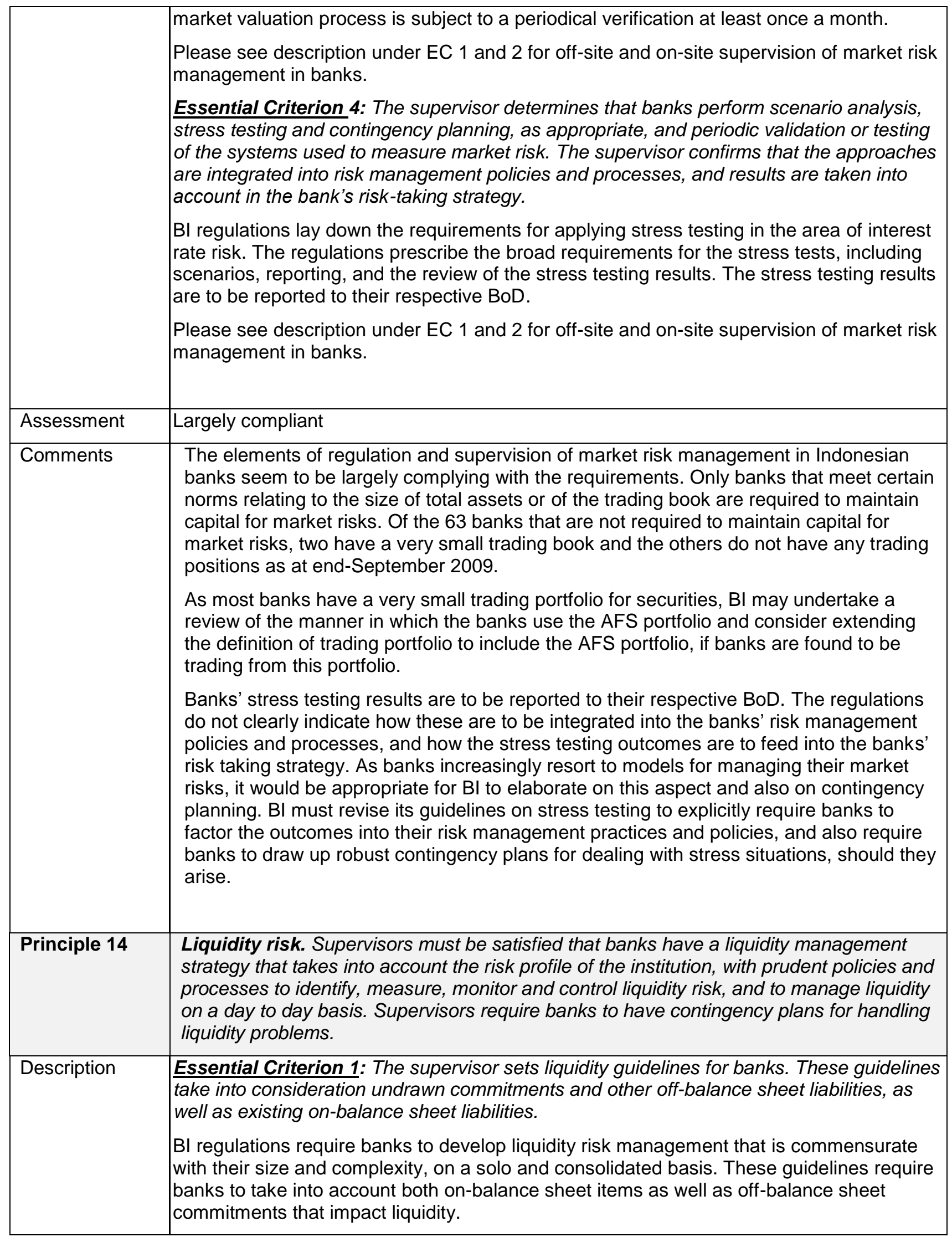


More recently, in July 2009, BI issued a circular letter on liquidity risk management, to better align Bl's regulatory expectations with the Principles for Sound Liquidity Risk Management and Supervision recommended by BCBS in September 2008. These guidelines become operational on October 30, 2009. Bl's revised guidelines cover major issues, such as: (a) funding strategies; (b) management of liquidity position and daily liquidity risks; (c) management of intra-group liquidity positions and liquidity risks; (d) maintenance of an adequate level of unencumbered liquid assets as a regulatory backstop; (e) the need to develop early warning triggers; and (f) establishment of a robust stress testing framework and Contingency Funding Plan (CFP), including the designation of a liquidity crisis team that is responsible for execution of the CFP. In order to help implement the new guidance through the frontline supervisors, $\mathrm{BI}$ is in the process of enhancing internal guidance for liquidity management supervision, including the tools used to monitor liquidity position and risk.

Regulations allow banks to slot the cash flows into the various time (maturity) buckets using their own assumptions and behavioral pattern for their assets and liabilities.

Regulations do not lay down the standards or benchmarks for slotting the various items of assets and liabilities.

$\mathrm{BI}$ regulations, however, require banks to maintain minimum reserve requirements at two levels (primary and secondary) with reference to third party funds (in Indonesian Rupiah and foreign currencies) and the bank's loan-to-deposit ratio, in the form of deposits with BI.

Essential Criterion 2: The supervisor confirms that banks have a liquidity management strategy, as well as policies and processes for managing liquidity risk, which have been approved by the Board. The supervisor also confirms that the Board has an oversight role in ensuring that policies and processes for risk-taking are developed to monitor, control and limit liquidity risk, and that management effectively implements such policies and processes.

(Please see description for EC 2 and EC 3)

$\mathrm{BI}$ regulations require that the $\mathrm{BoC}$ and the $\mathrm{BoD}$ must understand liquidity risk and actively engage in approving and evaluating the policy and strategy for liquidity risk management on a regular basis.

Supervisors conduct an off-site analysis and review bank's liquidity risk profile using the risk profile rating system and CAMELS. The combination of both quantitative (" $L$ " in CAMELS) and qualitative tools (liquidity risk profile in the risk profile system) provides the basis for ongoing monitoring of liquidity risk.

As a part of the off-site liquidity risk supervision, supervisors rely on several reports submitted by banks, e.g. : daily cash flow projections, weekly report of primary reserve position, bimonthly bank's maturity profile report, quarterly risk profile report, and other related reports. In addition, supervisors also make use of other sources of information such as: Know Your Bank (KYB) material and previous audit report(s). Based on this information, supervisors conduct an analysis and review of a bank's liquidity risk profile.

The review of a bank's liquidity risk profile focuses on inherent risk and the risk control system. Supervisors assess the inherent liquidity risk of the bank's functional activities, e.g., treasury, investment and funding department, etc. The adequacy of the bank's risk management is reviewed with reference to:

i. active oversight by board and commissioners;

ii. adequacy of policies, procedures, and limits;

iii. adequacy of the processes for identification, measurement, and monitoring of risk, and of the management information system; and 
iv. effectiveness of the internal control system.

$\mathrm{BI}$ reviews liquidity management by monitoring certain ratios such as reserve ratio, maturity mismatch, loan to deposit ratio (LDR), cash flow projection, deposit concentration, liquidity policy and management, and access to funding sources. The result of the assessment determines the individual supervisory strategy and audit plan for liquidity risk.

Supervisory review includes the adequacy of the liquidity risk management framework and its implementation; limit setting and compliance; the actual liquidity position of the bank (current and prospective); liquidity risk monitoring; and stress testing and the contingency plan.

$\mathrm{BI}$ has introduced a daily surveillance on liquidity risk, as a part of the early warning system. The surveillance focuses on the cash flow projection, the secondary reserve position, and the foreign exchange liquidity of 14 big banks. In addition, the surveillance also covers the liquidity of medium-size and small banks, focusing on the inter-linkage and the potential contagion effect on the liquidity of the 14 big banks.

Essential Criterion 3: The supervisor determines that a bank's senior management has defined (or established) appropriate policies and processes to monitor, control and limit liquidity risk; implements effectively such policies and processes; and understands the nature and level of liquidity risk being taken by the bank.

Please see description under EC 2.

Essential Criterion 4: The supervisor requires banks to establish policies and processes for the ongoing measurement and monitoring of net funding requirements. The policies and processes include considering how other risks (e.g. credit, market and operational risk) may impact the bank's overall liquidity strategy, and require an analysis of funding requirements under alternative scenarios, diversification of funding sources, a review of concentration limits, stress testing, and a frequent review of underlying assumptions to determine that they continue to be valid.

$\mathrm{BI}$ regulations require banks to establish policies and processes for ongoing measurement and monitoring of net funding requirements, conduct periodical stress testing, and conduct periodical contingency funding plan testing to anticipate and handle crisis situations.

The stress testing regulations, among others, require banks to perform both bank-specific scenarios and general market stress scenarios. The bank specific scenarios include a decline in external rating, a massive fund withdrawal, an increase in NPLs, disturbance to the bank's operational systems, disruption in accessing secured or unsecured funding, and limitations in undertaking currency conversions. The outcomes of these stress tests feed into the liquidity risk management framework, which also requires periodical testing of the validity of the contingency funding plan (CFP).

$\mathrm{BI}$ regulations on funding strategy include diversification of funding sources (counterparty, market, geographical) and funding types (secured, unsecured, instruments, currencies); and maintaining market access (increasing number of standby arrangements; active participation and relationships with fund suppliers).

Essential Criterion 5: The supervisor obtains sufficient information to identify those institutions carrying out significant foreign currency liquidity transformation. Where a bank or banking group's foreign currency business, either directly, or indirectly through lending in foreign exchange to domestic borrowers, is significant, or where a particular currency in which the bank has material exposure is experiencing problems, the supervisor requires the bank to undertake separate analysis of its strategy for each currency individually and, 


\begin{tabular}{|c|c|}
\hline & $\begin{array}{l}\text { where appropriate, set and regularly review limits on the size of its cash flow mismatches } \\
\text { for foreign currencies in aggregate and for each significant individual currency. }\end{array}$ \\
\hline & $\begin{array}{l}\text { BI obtains from all banks a monthly maturity profile report that covers the maturity profile in } \\
\text { local currency and foreign currency separately, but regulations do not explicitly require } \\
\text { banks to manage the liquidity risk in their foreign currency portfolios. }\end{array}$ \\
\hline & $\begin{array}{l}\text { Essential Criterion 6: The supervisor determines that banks have contingency plans in } \\
\text { place for handling liquidity problems, including informing the supervisor. }\end{array}$ \\
\hline & $\begin{array}{l}\text { The BI regulations require banks to have in place CFPs that would ensure stable sources, } \\
\text { stable costs of funding, and availability of adequate liquid assets, in the light of likely } \\
\text { delays in inflows and/ or acceleration of outflows. Regulations also require banks to } \\
\text { periodically review the customer relations strategy, diversification of deposits, and testing } \\
\text { of the validity of the CFP. }\end{array}$ \\
\hline & $\begin{array}{l}\text { The BI has recently issued comprehensive regulations on liquidity risk management that } \\
\text { become operational on October } 30,2009 \text {. These regulations require banks to have CFPs } \\
\text { that will be able to meet the normal as well as various crisis situations as appropriate to } \\
\text { banks' risk profile and stress test results. The regulations require the CFP to include } \\
\text { coordination plans for meeting crisis situations; and documentation, evaluation, periodical } \\
\text { testing and updating of the CFP. }\end{array}$ \\
\hline & $\begin{array}{l}\text { The regulations do not explicitly require banks to inform the BI when their CFPs are } \\
\text { triggered or when they are facing liquidity problems. }\end{array}$ \\
\hline Assessment & Largely Compliant \\
\hline Comments & $\begin{array}{l}\text { BI should review the existing regulations and supervisory framework to cover the following } \\
\text { aspects: } \\
\text { - BI regulations do not explicitly require banks to manage their foreign currency } \\
\text { liquidity risk. } \\
\text { BI regulations allow banks to slot the cash flows into the various time (maturity) } \\
\text { buckets using their own assumptions and behavioral pattern for their assets and } \\
\text { liabilities. The guidelines do not lay down the standards or benchmarks for slotting } \\
\text { the various items of assets and liabilities. The BI has not developed benchmark } \\
\text { maturity mismatch limits that will aid timely supervisory intervention. These two } \\
\text { aspects prevent meaningful system-wide aggregation, comparison, and } \\
\text { monitoring of the liquidity position in banks. } \\
\text { Regulations do not explicitly require banks to inform the BI when their CFPs are } \\
\text { triggered or when they are facing liquidity problems. } \\
\text { Additionally, BI must ensure effective implementation by banks of the various elements of } \\
\text { their guidelines issued in July 2009, with particular reference to diversification of funding } \\
\text { sources, stress testing, and validity of the CFPs. }\end{array}$ \\
\hline Principle 15 & $\begin{array}{l}\text { Operational risk Supervisors must be satisfied that banks have in place risk management } \\
\text { policies and processes to identify, assess, monitor and control/mitigate operational risk. } \\
\text { These policies and processes should be commensurate with the size and complexity of } \\
\text { the bank. }\end{array}$ \\
\hline Description & $\begin{array}{l}\text { Essential Criteria 1: The supervisor requires individual banks to have in place risk } \\
\text { management policies and processes to identify, assess, monitor and mitigate operational } \\
\text { risk. These policies and processes are adequate for the size and complexity of the bank's } \\
\text { operations, and the supervisor confirms that they are periodically adjusted in the light of } \\
\text { the bank's changing risk profile and external market developments. }\end{array}$ \\
\hline & $\begin{array}{l}\mathrm{BI} \text { regulations define operational risk, but do not include legal risk, which is addressed } \\
\text { separately, and require banks to develop an operational risk management framework that }\end{array}$ \\
\hline
\end{tabular}


is commensurate with their size and complexity, on a solo and consolidated basis.

$\mathrm{BI}$ has also established a regulation concerning risk management in the use of information technology (IT) by banks. The regulation requires that banks submit regular reports on their IT system and any significant modifications that might impact the operational risk profile. Regulation requires banks to obtain approval for the off-shore outsourcing of data centers, disaster recovery centers and/or IT-based transactions processing.

Regulations require banks to maintain capital for operational risk using the Basic Indicator Approach under Basel II. Implementation will be phased over 3 stages starting January 2010, June 2010, and January 2011, when banks should apply an alpha factor of 5 percent, 10 percent, and 15 percent, respectively.

(Please see description under EC 2 and 3 also)

Essential Criterion 2: The supervisor requires that banks' strategies, policies and processes for the management of operational risk have been approved and are periodically reviewed by the Board. The supervisor also requires that the Board oversees management in ensuring that these policies and processes are implemented effectively.

$\mathrm{BI}$ regulations require that banks' $\mathrm{BoC}$ and $\mathrm{BoD}$ must understand operational risk and work actively to approve and evaluate the policy and strategy for operational risk management on a regular basis. BoD must elaborate and communicate the policy and strategy for operational risk to all relevant units and evaluate the implementation of this policy and strategy.

Essential Criterion 3: The supervisor is satisfied that the approved strategy and significant policies and processes for operational risk are implemented effectively by management.

For conducting off-site supervision of operational risk, supervisors rely on several reports submitted by banks, e.g. quarterly risk profile report, semi-annual internal audit report, annual external audit report, and any other additional ad-hoc reports, where considered necessary, on loss event data, key risk indicators, scorecards, etc. In addition, they also use other sources of information such as Know Your Bank (KYB) material and previous $\mathrm{BI}$ audit reports.

Based on this information, supervisors conduct an analysis and review of a bank's operational risk profile. The review of operational risk profile is on inherent risk and the risk control system. Supervisors review the adequacy of a bank's risk management based on the ability of the bank to meet the four pillars of sound risk management : (a) active oversight by board and commissioners; (b) adequacy of policies, procedures, and limits; (c) adequacy of risk identification, measurement and monitoring, and of the management information system; and (d) an effective internal control system. The parameters used by supervisors, among others, include system failure or malfunction, accounting error, delay and mistakes in settlement, fraud, strategic failure, etc. The result of the review determines the individual supervisory strategy and audit plan for operational risk. Business lines, activities, and functions with the highest risk profile are accorded the highest priority in the on-site supervision.

Bl's supervisory efforts to understand banks' implementation of their operational risk management framework is dependent largely on the on-site examination process, as operational risk assessments require a heightened degree of transaction testing to ensure that stated policies and processes are applied in day-to-day risk management.

Supervisors examine and review the adequacy of operational risk policies and procedures as well as the operational risk control and monitoring process to ensure its adequacy with regard to the banks' operational risk profile and culture, and its effective implementation. 
The review also covers policies and procedures on intra bank transactions and intra group transactions, new activities and products, the IT system, outsourcing activities, and any other significant activities.

Essential Criterion 4: The supervisor reviews the quality and comprehensiveness of the bank's business resumption and contingency plans to satisfy itself that the bank is able to operate as a going concern and minimise losses, including those that may arise from disturbances to payment and settlement systems, in the event of severe business disruption.

$\mathrm{BI}$ regulations do not explicitly dwell on the importance of and need for business continuity planning, and the need for banks to address these aspects as a part of their operational risk management frameworks. Banks are required to have in place business continuity planning and test them periodically in the context of the use of the IT systems. As a result, banks tend to confine business continuity planning to IT applications, but may not extend their scope to address this issue at a whole bank level.

Supervisors review banks' contingency plans to ensure that banks' IT systems have the capability to cope with problems, internal or external threats, and any other unfavorable circumstances such as disturbance or failure of the payment and settlement system, natural disaster, malicious programs or viruses, etc.

Essential Criterion 5: The supervisor determines that banks have established appropriate information technology policies and processes that address areas such as information security and system development, and have made investments in information technology commensurate with the size and complexity of operations.

$\mathrm{BI}$ regulations address risk management issues pertaining to the use of IT in banks. The regulations require that risk management in the use of IT must include active supervision by the BoC and BoD; sufficient policies and procedures; and sufficient processes for identification, measurement, monitoring, and control of risks; and internal controls.

Supervisory review includes whether banks' systems and IT are commensurate with the nature and volume of transactions, produce complete and accurate reports, are equipped to detect and review any deviation in a timely manner for reducing the likelihood of a loss event, and provide timely reports for decision making. Supervisors also assess the adequacy of information system control in banks.

Essential Criterion 6: The supervisor requires that appropriate reporting mechanisms are in place to keep the supervisor apprised of developments affecting operational risk at banks in their jurisdictions.

Regulations do not explicitly mandate a reporting system or requirement on banks for apprising the $\mathrm{Bl}$ of developments affecting their operational risk.

Essential Criterion 7: The supervisor confirms that legal risk is incorporated into the operational risk management processes of the bank.

$\mathrm{BI}$ regulations do not address legal risk as a component of operational risk, but it is addressed separately. The regulations on legal risk apply only to large banks and those that have complex business operations. Legal risk is excluded from the purview of the risk profile assessment and reporting frameworks of banks below the threshold.

In light of the weaknesses in the domestic legal framework, this gap gains greater 


\begin{tabular}{|c|c|}
\hline & 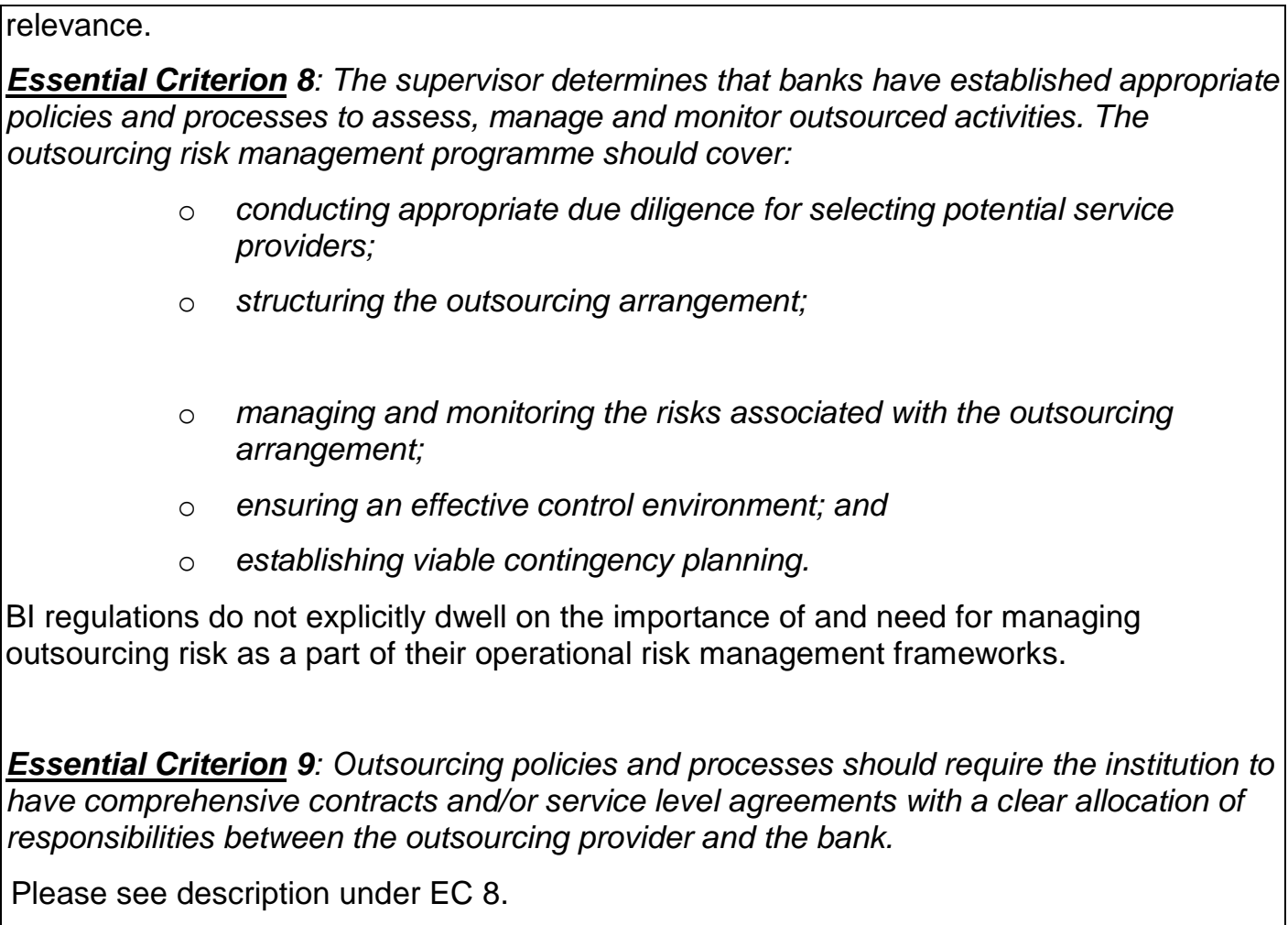 \\
\hline Assessment & Largely Compliant \\
\hline Comments & $\begin{array}{l}\text { BI regulations do not explicitly capture the following elements related to operational risk. } \\
\text { The regulations for and supervision of operational risk may be reviewed to include these } \\
\text { elements to ensure that operational risks in the Indonesian banking system are addressed } \\
\text { comprehensively. } \\
\text { - The importance of and need for managing outsourcing risk as a part of banks' } \\
\text { operational risk management framework. } \\
\text { - The importance of and need for business continuity planning (in areas other than } \\
\text { IT applications), and the need for banks to address these aspects as a part of } \\
\text { their operational risk management framework. } \\
\text { - The risk management framework and regulations on legal risk apply only to large } \\
\text { banks and those that have complex business operations. In light of the } \\
\text { weaknesses in the domestic legal framework, BI must consider extending the } \\
\text { legal risk management requirements to all banks. } \\
\text { - Regulations do not explicitly mandate a reporting system or requirement on banks } \\
\text { for apprising the BI of significant developments affecting their operational risk. }\end{array}$ \\
\hline Principle 16 & $\begin{array}{l}\text { Interest rate risk in the banking book Supervisors must be satisfied that banks have } \\
\text { effective systems in place to identify, measure, monitor and control interest rate risk in } \\
\text { the banking book, including a well defined strategy that has been approved by the Board } \\
\text { and implemented by senior management; these should be appropriate to the size and } \\
\text { complexity of such risk. }\end{array}$ \\
\hline Description & $\begin{array}{l}\text { Essential Criterion 1: The supervisor determines that a bank's Board approves, and } \\
\text { periodically reviews, the interest rate risk strategy and policies and processes for the } \\
\text { identification, measuring, monitoring and control of interest rate risk. The supervisor also } \\
\text { determines that management ensures that the interest rate risk strategy, policies and }\end{array}$ \\
\hline
\end{tabular}




\begin{tabular}{|c|c|}
\hline & processes are developed and implemented. \\
\hline & $\begin{array}{l}\text { BI regulations on risk management in banks cover market risk but do not explicitly cover } \\
\text { interest rate risk in the banking book (IRRBB) separately. At present, the focus of } \mathrm{BI} \\
\text { supervision is on interest rate risk in the trading book, which is covered through the } \\
\text { supervisory framework for market risk management in banks. }\end{array}$ \\
\hline & $\begin{array}{l}\text { Essential Criterion 2: The supervisor determines that banks have in place } \\
\text { comprehensive and appropriate interest rate risk measurement systems and that any } \\
\text { models and assumptions are validated on a regular basis. It confirms that banks' limits } \\
\text { reflect the risk strategy of the institution and are understood by and regularly } \\
\text { communicated to relevant staff. The supervisor also confirms that exceptions to } \\
\text { established policies, processes and limits should receive the prompt attention of senior } \\
\text { management, and the Board where necessary. }\end{array}$ \\
\hline & $\begin{array}{l}\text { In the absence of an off-site report on IRRBB, management of this risk by banks is not } \\
\text { monitored and assessed as part of the off-site process. Although banks are not formally } \\
\text { required to develop specific measurement tools, in practice a few large banks have } \\
\text { developed various tools such as: repricing gap, Value at Risk (VaR), Economic Value of } \\
\text { Equity (EVE) and Earning at Risk (EaR). These banks are using their internal models and } \\
\text { methodologies for measuring, monitoring and managing their exposures to IRRBB. As } \\
\text { these models are used for management purposes, banks' internal models are not subject } \\
\text { to intense supervisory reviews and assessments by BI. In the absence of detailed } \\
\text { regulations and benchmarks for application, IRRBB is not a formal focus of supervisory } \\
\text { review. }\end{array}$ \\
\hline & $\begin{array}{l}\text { Essential Criterion 3: The supervisor requires that banks periodically perform appropriate } \\
\text { stress tests to measure their vulnerability to loss under adverse interest rate movements. }\end{array}$ \\
\hline & $\begin{array}{l}\text { BI guidelines require banks to undertake stress tests as a part of their risk management } \\
\text { framework with regard to market risk and liquidity risk, but not for IRRBB. }\end{array}$ \\
\hline Assessment & Non-compliant \\
\hline Comments & $\begin{array}{l}\text { Banks in Indonesia are not explicitly managing IRRBB. A few large banks have made a } \\
\text { beginning in this regard in terms of developing internal models to measure and monitor the } \\
\text { level of these risks. The outputs of these models are used primarily to shape their internal } \\
\text { business strategies with a view to enhancing their risk returns. }\end{array}$ \\
\hline & $\begin{array}{l}\text { BI would do well to address this gap in the risk management framework of banks in } \\
\text { Indonesia at the earliest by (a) putting in place appropriate guidelines that address } \\
\text { identification, measurement, monitoring, reporting, management, and stress testing of } \\
\text { IRRBB; (b) introducing appropriate off-site reporting; (c) factoring this element of risk } \\
\text { formally into its off-site and on-site supervision; and (d) requiring appropriate disclosure } \\
\text { requirements for banks. }\end{array}$ \\
\hline & $\begin{array}{l}\text { It would also be useful for banks to develop appropriate methodologies for linking their } \\
\text { IRRBB exposures to capital requirements and for providing feedback to the management } \\
\text { as well as the supervisor on the outcomes of stress testing. }\end{array}$ \\
\hline Principle 17 & $\begin{array}{l}\text { Internal control and audit Supervisors must be satisfied that banks have in place } \\
\text { internal controls that are adequate for the size and complexity of their business. These } \\
\text { should include clear arrangements for delegating authority and responsibility; separation } \\
\text { of the functions that involve committing the bank, paying away its funds, and accounting } \\
\text { for its assets and liabilities; reconciliation of these processes; safeguarding the bank's } \\
\text { assets; and appropriate independent internal audit and compliance functions to test }\end{array}$ \\
\hline
\end{tabular}




\begin{tabular}{|c|c|}
\hline & adherence to these controls as well as applicable laws and regulations. \\
\hline \multirow[t]{10}{*}{ Description } & $\begin{array}{l}\text { Essential Criterion 1: Laws, regulations or the supervisor establish the responsibilities of } \\
\text { the Board and senior management with respect to corporate governance to ensure that } \\
\text { there is effective control over a bank's entire business. }\end{array}$ \\
\hline & $\begin{array}{l}\text { BI regulations require the Board of Commissioners (BoC) and the Board of Directors } \\
\text { (BoD) in banks to ensure implementation of good corporate governance (GCG) principles } \\
\text { in each of their business activities at all organizational levels or hierarchy. The regulation } \\
\text { delineates the duties and responsibilities of the boards. In addition, it also requires banks } \\
\text { to establish (a) several committees under the BoC, namely the audit committee, risk } \\
\text { monitoring committee, and nomination and remuneration committee; and (b) certain } \\
\text { functions under the BoD, i.e. internal audit function, risk management function, risk } \\
\text { management committee, and compliance function. The regulations prescribe the broad } \\
\text { requirements of the BoC Committees and their roles and responsibilities. The regulations } \\
\text { require the BoC and the BoD to take follow-up action on audit findings and } \\
\text { recommendations from the bank's internal audit function, external auditor, Bl's } \\
\text { supervision, and / or other authorities' supervision. }\end{array}$ \\
\hline & Please see description under EC 2 also. \\
\hline & $\begin{array}{l}\text { Essential Criterion } 2 \text { : The supervisor determines that banks have in place internal } \\
\text { controls that are adequate for the nature and scale of their business. These controls are } \\
\text { the responsibility of the Board and/or senior management and deal with organizational } \\
\text { structure, accounting policies and processes, checks and balances, and the safeguarding } \\
\text { of assets and investments. More specifically, these controls address: }\end{array}$ \\
\hline & $\begin{array}{l}\text { - Organizational structure: definitions of duties and responsibilities, including clear } \\
\text { delegation of authority (for example, clear loan approval limits), decision-making } \\
\text { policies and processes, separation of critical functions (for example, business } \\
\text { origination, payments, reconciliation, risk management, accounting, audit and } \\
\text { compliance). }\end{array}$ \\
\hline & $\begin{array}{l}\text { - Accounting policies and processes: reconciliation of accounts, control lists, } \\
\text { information for management. }\end{array}$ \\
\hline & $\begin{array}{l}\text { - Checks and balances (or "four eyes principle"): segregation of duties, cross- } \\
\text { checking, dual control of assets, double signatures. }\end{array}$ \\
\hline & - Safeguarding assets and investments: including physical control. \\
\hline & $\begin{array}{l}\mathrm{BI} \text { regulations require the } \mathrm{BOC} \text { and } \mathrm{BOD} \text { to ensure the creation, maintenance, and } \\
\text { oversight of an effective internal control mechanism that aims at safeguarding and } \\
\text { securing the property and assets of the bank; ensuring greater accuracy in reporting; } \\
\text { strengthening legal and regulatory compliance; minimizing financial irregularities and } \\
\text { fraud; and improving efficiency. To achieve this, banks are required to develop internal } \\
\text { control systems that should at least cover: (a) management oversight and risk control } \\
\text { culture; (b) risk identification and measurement; (c) control activities and segregation of } \\
\text { duties; (d) accounting, information, and communication systems; and (e) monitoring } \\
\text { activities. Further, banks are required to designate a compliance director and establish an } \\
\text { independent internal audit unit. }\end{array}$ \\
\hline & $\begin{array}{l}\text { BI regulations require banks to submit an annual self-assessment with regard to } \\
\text { compliance with the GCG principles and a quarterly self-assessment with regard to its risk } \\
\text { profile. During on-site examinations, the supervisors are able to examine the adequacy of } \\
\text { (a) the implementation of the GCG principles; (b) the internal control system, including } \\
\text { delegation of duties and responsibilities; (c) the four-eyes principle for segregation of } \\
\text { duties and responsibilities; and (d) policies and procedures, decision making processes, } \\
\text { management of physical assets, and accounting and reporting systems. They are also }\end{array}$ \\
\hline
\end{tabular}


able to validate banks' GCG self- assessments during on-site examinations.

The on-site examinations, however, do not envisage a structured and comprehensive assessment of the entire internal control function in banks. The assessment of the internal control function is at present undertaken on a piecemeal basis and is confined to the areas of focus during the examination. When a bank approaches $\mathrm{BI}$ for prior approval to launch $\mathrm{a}$ new product, $\mathrm{BI}$ undertakes an assessment of the adequacy of the bank's related internal control mechanisms.

Essential Criterion 3: Laws, regulations or the supervisor place the responsibility for the control environment on the Board and senior management of the bank. The supervisor requires that the Board and senior management understand the underlying risks in their business and are committed to a strong control environment.

As indicated under EC 2, responsibility for the control environment has been placed on the $\mathrm{BoC}$ and the $\mathrm{BoD}$ of the bank. BI regulations on implementation of risk management have clearly established the responsibility of the BoD for implementation of the risk management policy and overall risk exposures assumed by the bank.

Essential Criterion 4: The supervisor has the power to require changes in the composition of the Board and senior management to address any prudential concerns related to the satisfaction of these criteria.

The regulations on GCG empower $\mathrm{BI}$ to impose administrative sanctions of varying degrees for non compliance with $\mathrm{BI}$ laws and regulations and other laws and regulations. The sanctions include (a) termination of bank management and appointment of temporary replacements until the shareholders appoint a regular replacement; and (b) inclusion of members of bank management, employees, and shareholders on the list of disqualified people through the fit and proper mechanism.

Essential Criterion 5: The supervisor determines that there is an appropriate balance in the skills and resources of the back office and control functions relative to the front office/business origination.

$\mathrm{BI}$ regulations specify the powers and responsibilities of the BOD with regard to risk management, which include ensuring increased competency of human resources. The regulations mention that banks' risk management policies should be determined, among others, by formulating a strategy for ensuring that the bank is managed by human resources possessing knowledge, experience, and expertise in risk management commensurate with the complexity of the business operations of the bank. The risk management guidelines further elaborate on the relevant HR requirements in the risk management function. Supervisors are able to test compliance.

Essential Criterion 6: The supervisor determines that banks have a permanent compliance function that assists senior management in managing effectively the compliance risks faced by the bank. The compliance function must be independent of the business activities of the bank. The supervisor determines that the Board exercises oversight of the management of the compliance function.

BI regulations require banks to appoint a Compliance Director (CD), who will be assisted by an independent compliance unit in charge of developing and updating procedures, systems, and working manuals. The requirements and procedures for CD appointment are stipulated in $\mathrm{BI}$ regulations. The appointment and removal of the $\mathrm{CD}$ can take place only with the decision of the BOC and the President Director and the prior approval of the BI. 
The CD is responsible for (a) ensuring that the bank has complied with all $\mathrm{BI}$ regulations and other prevailing laws and regulations pertaining to the implementation of prudential principles; (b) monitoring and ensuring that the business operations of the bank do not depart from the prevailing regulations; and (c) monitoring and ensuring that the bank has complied with all agreements and commitments made by the bank to the BI. The regulations require the $C D$ to provide regular reports to the President Director with a copy to the BOC. Banks are required to submit half-yearly reports to the $\mathrm{BI}$ on the key tasks performed by the $C D$ with reference to the responsibilities identified in the regulations. The oversight responsibility of the BOC is also stipulated in the GCG regulations.

Banks' compliance with the relevant regulations is assessed through the off-site reports required of banks with regard to the compliance function and the annual self-assessment reports. Further, these reports are verified for compliance during on-site examinations. Supervisors verify the independence and effectiveness of the $C D$ and the compliance unit in performing their roles. $\mathrm{BI}$ is empowered to withdraw its approval for a $\mathrm{CD}$ that fails to comply with regulations in force.

Essential Criterion 7: The supervisor determines that banks have an independent, permanent and effective internal audit function charged with (i) ensuring that policies and processes are complied with and (ii) reviewing whether the existing policies, processes and controls remain sufficient and appropriate for the bank's business.

$\mathrm{BI}$ regulations on GCG require banks to establish an internal audit function that is independent of the other operational units. The head of the internal audit function can be appointed or removed only by the President Director with the approval of the BoC. The internal audit function is required to report directly to the President Director. The internal audit function is assigned responsibility for conducting the internal audit as well as preparing and updating the internal guidelines on the various aspects covered by $\mathrm{BI}$ regulations. The internal audit responsibilities include analyses and evaluation of financial, accounting, operational, and other activities through both on-site and off-site reporting.

Essential Criterion 8 : The supervisor determines that the internal audit function:

- $\quad$ has sufficient resources, and staff that are suitably trained and have relevant experience to understand and evaluate the business they are auditing;

- has appropriate independence, including reporting lines to the Board and status within the bank to ensure that senior management reacts to and acts upon its recommendations;

- has full access to and communication with any member of staff as well as full access to records, files or data of the bank and its affiliates, whenever relevant to the performance of its duties;

- employs a methodology that identifies the material risks run by the bank;

- prepares an audit plan based on its own risk assessment and allocates its resources accordingly; and

- $\quad$ has the authority to assess any outsourced functions.

The $\mathrm{BI}$ undertakes an assessment of the internal audit function as part of the off-site supervision. Supervisors review several reports submitted by banks e.g.: quarterly risk profile, semi-annual internal audit report, semi-annual compliance director's report, GCG report, management letter, annual audit report, and any other additional reports if considered necessary. In addition, supervisors also make use of other sources of information such as : Know Your Bank (KYB) material and previous BI audit reports. 


\begin{tabular}{|c|c|}
\hline & $\begin{array}{l}\text { Based on the semi-annual internal audit report, supervisors review, among other things, } \\
\text { performance of the internal audit function including audit findings perceived to threaten the } \\
\text { bank's business continuity, as well as a review of the internal audit's performance done by } \\
\text { an external party. } \\
\text { As mentioned under EC 2, the on-site examinations do not envisage a structured and } \\
\text { comprehensive assessment of the internal control function in banks, in its entirety. The on- } \\
\text { site assessment is undertaken on a piecemeal basis and is generally confined to the areas } \\
\text { of focus during the examination. Internal control is one of the three elements that is } \\
\text { assessed under the 'M' of CAMELS. The rating methodology does not provide for } \\
\text { separate weights for this aspect within ' } M \text { '. }\end{array}$ \\
\hline Assessment & Largely Compliant \\
\hline Comments & $\begin{array}{l}\text { BI should review the following aspects pertaining to internal control and audit in banks and } \\
\text { adopt appropriate remedial measures: } \\
\text { - BI does not assess the internal control function as a separate function. It is } \\
\text { generally assessed indirectly on a piecemeal basis with reference to a relevant } \\
\text { internal control system as and when a bank approaches the BI for approval to } \\
\text { launch a new product or when BI undertakes on-site visits. } \\
\text { - Banks' internal control functions seem to lack the capacity as well as } \\
\text { methodologies for validation of internal models, including stress test models, } \\
\text { either by themselves or through outsourcing. } \\
\text { - BI regulations do not explicitly require a risk based audit framework in banks. } \\
\text { Although some banks tend to adopt some risk basis for the audits, the banks' } \\
\text { internal control and audit functions are not adequately risk based. }\end{array}$ \\
\hline Principle 18 & $\begin{array}{l}\text { Abuse of financial services. Supervisors must be satisfied that banks have adequate } \\
\text { policies and processes in place, including strict "know-your-customer" rules, that } \\
\text { promote high ethical and professional standards in the financial sector and prevent the } \\
\text { bank from being used, intentionally or unintentionally, for criminal activities. }\end{array}$ \\
\hline Description & $\begin{array}{l}\text { Essential Criterion 1: Laws or regulations clarify the duties, responsibilities and powers } \\
\text { of the banking supervisor and other competent authorities, if any, related to the } \\
\text { supervision of banks' internal controls and enforcement of the relevant laws and } \\
\text { regulations regarding criminal activities. } \\
\text { Law No. } 15 \text { Year } 2002 \text { concerning Crime of Money Laundering as amended by Law No. } \\
25 \text { Year } 2003 \text { ("AML Law") specifies the duties and responsibilities of the PPATK } \\
\text { (Indonesian FIU) with regard to preventing and eradicating the crime of money laundering } \\
\text { and its authority over banks in this regard. BI regulations detail BI's responsibilities and } \\
\text { powers in this regard. } \\
\text { Essential Criterion 2: The supervisor must be satisfied that banks have in place } \\
\text { adequate policies and processes that promote high ethical and professional standards and } \\
\text { prevent the bank from being used, intentionally or unintentionally, for criminal activities. } \\
\text { This includes the prevention and detection of criminal activity, and reporting of such } \\
\text { suspected activities to the appropriate authorities. } \\
\text { Banks are required to file regular compliance reports and BI examiners carefully check } \\
\text { compliance. Suspicious transaction reports are filed with the PPATK. } \\
\text { An APG } 2008 \text { mutual evaluation report of the Indonesian AML / CFT framework revealed } \\
\text { several shortcomings that include the operation of large-Scale unregulated informal } \\
\text { remittance channels outside the purview of the national AML/CFT measures; absence of } \\
\text { regulation and supervision of money remitters; inadequate AML/CFT regime for money }\end{array}$ \\
\hline
\end{tabular}


remitters; absence of comprehensive wire transfer obligations; absence of guidance to banks regarding the identification of high risk countries; and lack of comprehensive instructions for application of AML/CFT norms to subsidiaries outside Indonesia.

$\mathrm{BI}$ has since issued regulations (11/28/PBI/2009 and SE 11/31/DPNP) to banks providing guidance and requirements on AML / CFT norms for foreign subsidiaries, wire transfer procedures, and identification of high risk countries.

Essential Criterion 3: In addition to reporting to the financial intelligence unit or other designated authorities, banks report to the banking supervisor suspicious activities and incidents of fraud when they are material to the safety, soundness or reputation of the bank.

Copies of suspicious transaction reports (STRs) filed with PPATK are not reported to the $\mathrm{BI}$, which was cited as a handicap by the supervisors in exercising more effective supervision over AML/CFT. STRs can be reviewed during inspections, which are conducted at least annually. Banks are required to report any transaction that involves fraud or breaches of prevailing regulations.

Essential Criterion 4: The supervisor is satisfied that banks establish "know-yourcustomer" $(K Y C)$ policies and processes which are well documented and communicated to all relevant staff. Such policies and processes must also be integrated into the bank's overall risk management. The KYC management programme, on a group-wide basis, has as its essential elements:

- $\quad$ a customer acceptance policy that identifies business relationships that the bank will not accept;

- a customer identification, verification and due diligence programme; this encompasses verification of beneficial ownership and includes risk-based reviews to ensure that records are updated and relevant;

- $\quad$ policies and processes to monitor and recognize unusual or potentially suspicious transactions, particularly of high-risk accounts;

- $\quad$ escalation to the senior management level of decisions on entering into business relationships with high-risk accounts, such as those for politically exposed persons, or maintaining such relationships when an existing relationship becomes high-risk; and

- $\quad$ clear rules on what records must be kept on consumer identification and individual transactions and their retention period. Such records should have at least a five year retention period.

At least annually, supervisors conduct an assessment of the implementation of KYC and anti-money laundering controls including management oversight, policies, practices and procedures, internal controls and audit of MIS systems and training. Banks confirm that the inspections are thorough.

Article 21 of $\mathrm{BI}$ regulations (11/28/PBI/2009) allows banks to (a) undertake business relations with customers before completion of verification of documents, and (b) complete the verification within 14 working days after undertaking business relations with individual customers and 90 working days after undertaking business relations with corporate customers. This relaxation is also allowed for walk-in customers. This would seem to provide a serious gap in regulations that can expose the Indonesian banking system to abuse.

The APG 2008 mutual evaluation revealed that financial institutions do not appear to have 
a clear understanding of the extent of obligations on identification and verification of beneficial owners. Financial institutions need to establish clear internal control policies to implement enhanced customer due diligence (CDD) measures. There is no explicit requirement to perform CDD when there is doubt about the veracity of the CDD information previously obtained. There is no explicit requirement to perform CDD when $\mathrm{ML}$ or TF is suspected, regardless of any other exemption. Legal persons are not required to maintain a record of beneficial owners or whether company shareholdings are held beneficially, and the Companies Registry has not yet established a publicly available central registry of current information about legal persons. Banks are not required to terminate or limit business relationships with banks that do not provide full originator information. Effective implementation by banks of the requirement to ensure that their correspondent banks do not permit shell banks as customers was not demonstrated. Banks are not required to obtain senior management approval to continue business relationships with a customer who becomes a politically exposed person (PEP).

$\mathrm{BI}$ has since issued regulations (PBI 11/28/09), which clarify the regulatory requirements pertaining to CDD on beneficial owners, when information previously provided by customers is in doubt, when ML or TF is suspected, and for continuing business relationships with customers classified as PEP.

Essential Criterion 5 : The supervisor is satisfied that banks have enhanced due diligence policies and processes regarding correspondent banking. Such policies and processes encompass:

- $\quad$ gathering sufficient information about their respondent banks to understand fully the nature of their business and customer base, and how they are supervised; and

- $\quad$ not establishing or continuing correspondent relationships with foreign banks that do not have adequate controls against criminal activities or that are not effectively supervised by the relevant authorities, or with those banks that are considered to be shell banks.

Part Nine Article 31 of the latest Act and $\mathrm{BI}$ regulation (11/28/PBI/2009) require minimal checking of cross-border correspondent bank relationships.

The APG mutual evaluation in 2008 noted weaknesses in many areas including correspondent banking. Please see description under EC 4 also.

Essential Criterion 6 : The supervisor periodically confirms that banks have sufficient controls and systems in place for preventing, identifying and reporting potential abuses of financial services, including money laundering.

Annual on-site examinations are conducted.

Essential Criterion 7: The supervisor has adequate enforcement powers (regulatory and/or criminal prosecution) to take action against a bank that does not comply with its obligations related to criminal activities.

$\mathrm{BI}$ has adequate powers to levy fines, downgrade the bank rating, issue a cease and desist order, register as unfit any officer, staff or shareholder, or dismiss management for breaches of the Act.

The APG mutual evaluation in 2008 revealed that implementation of effective sanctions is not consistent across all sectors. Effectiveness has been hampered by an avoidance of monetary penalties and a reliance on other administrative sanctions by $\mathrm{BI}$. 


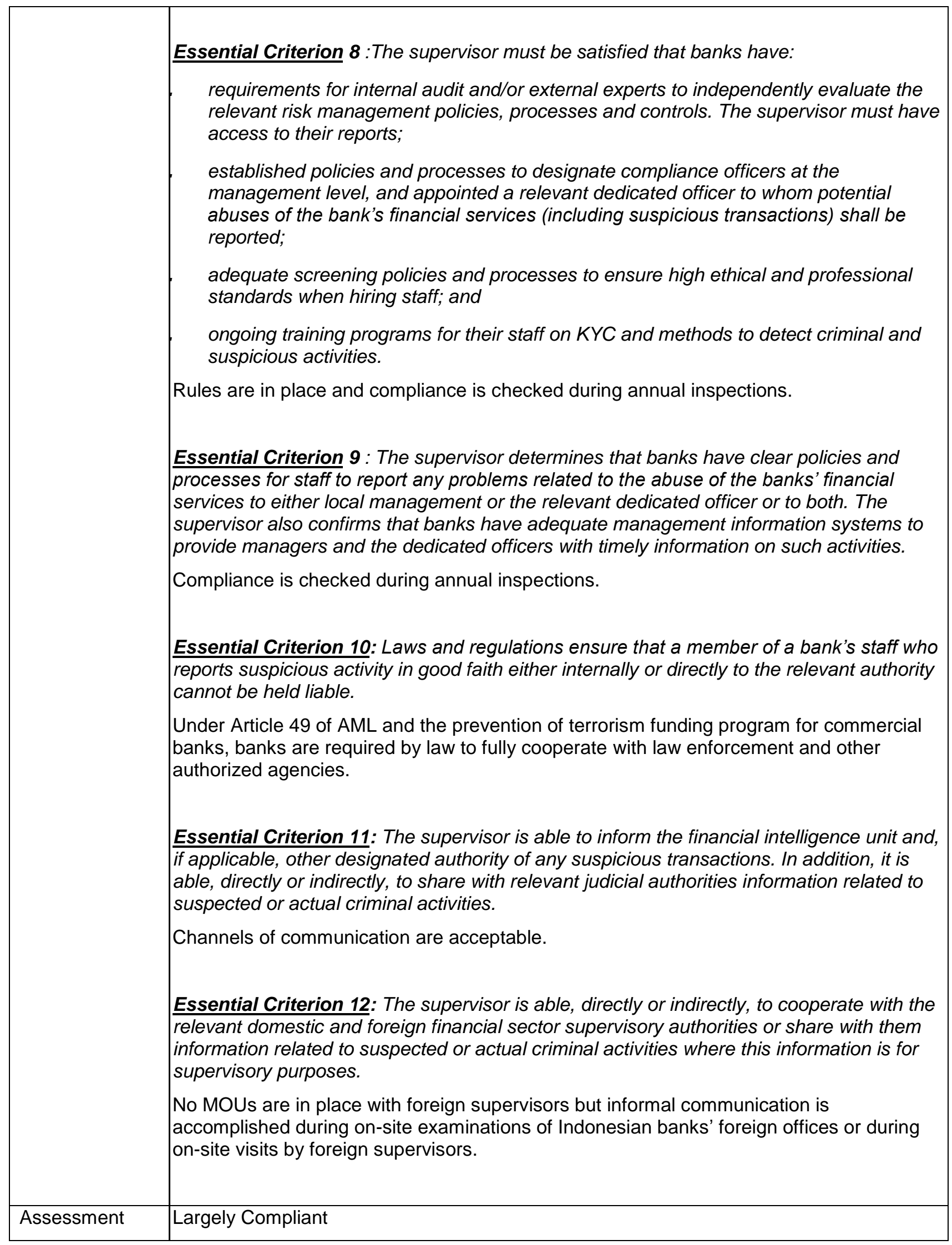




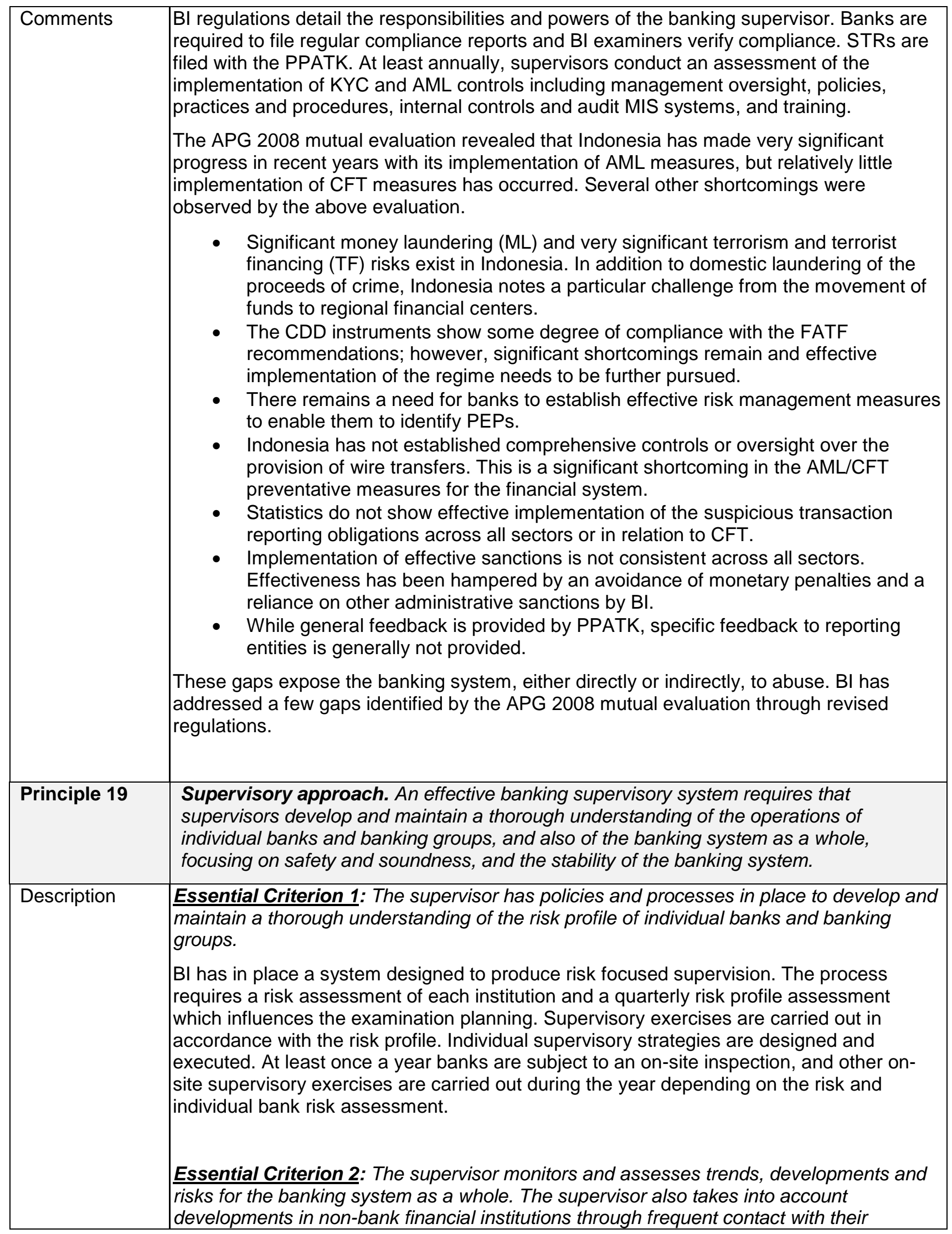


regulators.

Data reported by the banking system are aggregated by the Directorate of Banking Research and Regulation and used to form part of the formal reporting to the Board of Governors. The information appears to be rather comprehensive with charts and graphs used to highlight areas of interest. The report is long on information but short on deep analysis of trends, developments, and emerging risks. It is largely left to the reader to pick out areas of interest. There does not appear to be a detailed discussion of possible problem areas with an accompanying recommendation to the Board of suggested actions or ways forward. Information to the Board of Governors appears to flow from the bottom up, but there is scant evidence that the condition of the whole of the financial system is assessed other than the collective aggregation of CAMELS ratings. The supervisory approach seems to be relying on the principle that if the individual institutions are in collective good health then the system must be sound.

There are no formal MOUs in place between domestic supervisory agencies, with the exception of the deposit insurer. Transfer of information is informal and not routine at the operating level. To make up for this deficiency, the supervisors routinely check compliance and adherence to prudential norms by including the subsidiary in the scope of examination when, for example, checking for credit, operational, or market risk in the bank.

Development of supervisory benchmarks with regard to various performance indicators and compliance with regulatory requirements will immensely improve the quality of supervision.

Essential Criterion 3: The supervisor uses a methodology for determining and assessing on an ongoing basis the nature, importance and scope of the risks to which individual banks or banking groups are exposed. The methodology should cover, inter alia, the business focus, the risk profile and the internal control environment, and should permit relevant comparisons between banks. Supervisory work is prioritised based on the results of these assessments.

Individual banks and banking groups are assessed on a holistic basis using the risk based methods in place in Indonesia. Communication between the banks and the supervisors is frequent both on a routine and issue specific basis. Risk assessments are updated formally at least quarterly and more frequently if required. All relevant and pertinent areas are covered. Experienced examiners are in charge of the supervision of each banking institution, and credit, market and operational risk specialists are in place. Banks report that supervision skills are good and the addition of specialists in key areas is adding value. Supervisory priorities are amended on an institutional basis as the supervisor in charge deems necessary, with the concurrence of the Directorate head.

Essential Criterion 4: The supervisor confirms banks' and banking groups' compliance with prudential regulations and other legal requirements.

Banks are required to submit periodic off-site reports on various aspects of prudential regulations and requirements. Analyses of these reports help the supervisor to identify any breaches and conduct compliance checks. Further, compliance checks are routine during annual or special examinations. Bank adherence to prudential requirements is considered high.

Essential Criterion 5: The supervisor requires banks to notify it of any substantive changes in their activities, structure and overall condition, or as soon as they become aware of any material adverse developments, including breach of legal or prudential requirements. 


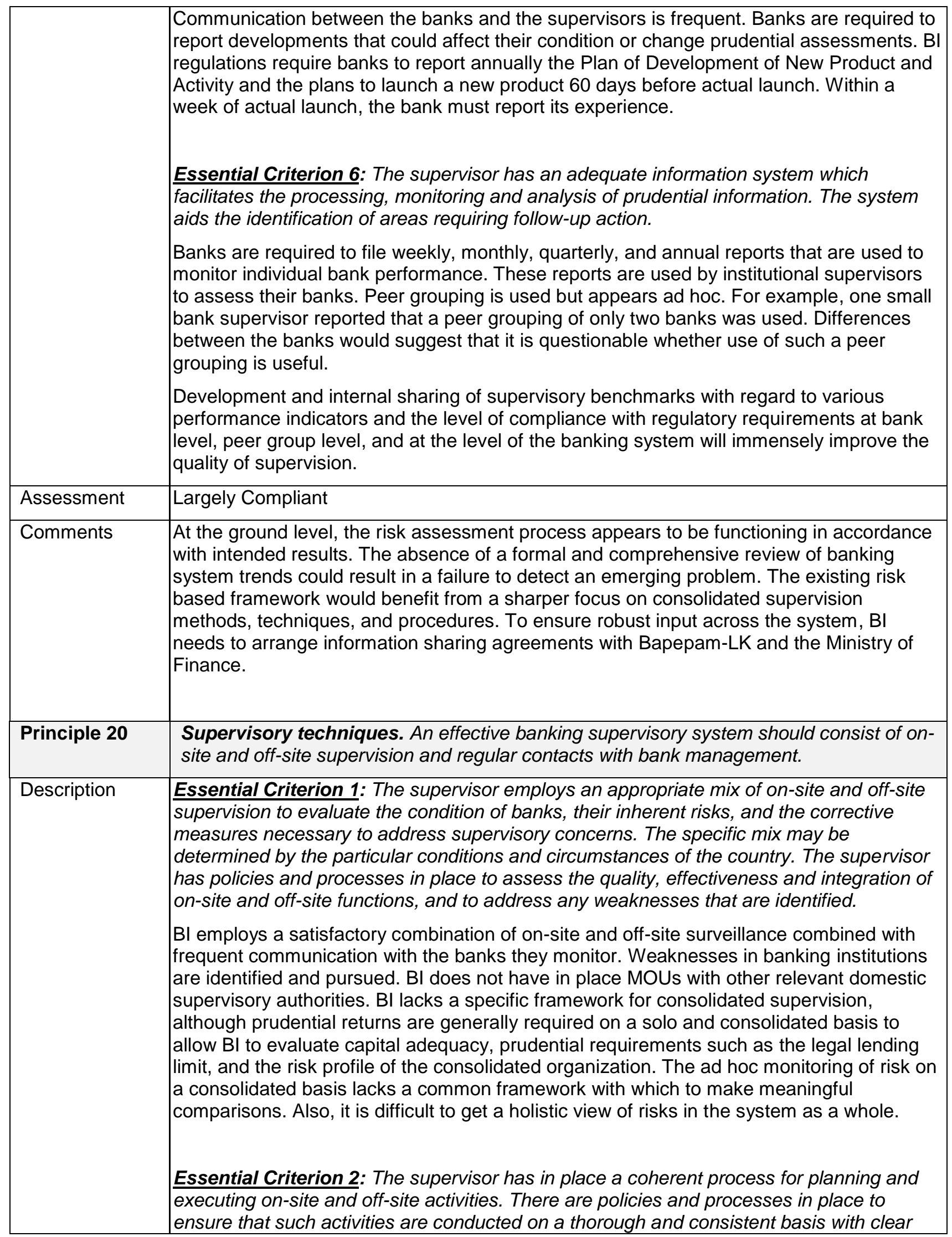


responsibilities, objectives and outputs, and that there is effective coordination and information sharing between the on-site and off-site functions.

The on-site and off-site supervisory functions were combined in 2006 to form a dedicated team for each bank, which also serves as the principal point of contact. The team concept works well and produces a healthy blend of a number of supervisory techniques to produce a customized approach for each major institution with the pillars of on-site and offsite surveillance at the center. Discussions with supervision team members showed that they have a good understanding of the risks in the banks in their portfolios. They expand supervisory visits to address specific concerns as warranted. Since they work together as a team, communication, coordination, and information sharing are not a problem. $\mathrm{BI}$ is encouraging supervisors to make more use of their supervisory judgments rather than overly relying on the quantitative factors emanating from the Surveillance Management Information System (SIMWAS) to flag emerging concerns. Supervisors appear experienced enough to move in this direction.

Essential Criterion 3: On-site work, conducted either by the supervisor's own staff or through the work of external experts, is used as a tool to:

- provide independent verification that adequate corporate governance (including risk management and internal control systems) exists at individual banks;

- determine that information provided by banks is reliable;

- obtain additional information on the bank and its related companies needed for the assessment of the condition of the bank, the evaluation of material risks, and the identification of necessary remedial actions and supervisory actions, including enhanced off-site monitoring; and

- monitor the bank's follow-up on supervisory concerns.

On-site examination is thorough both at the yearly visit as well as during the additional supervisory exercises conducted between the annual visits. Returns are thoroughly reviewed and monitored with frequent contact between the $\mathrm{BI}$ and the bank to ensure the validity of the numbers as well as the context. Supervisory exercises take account of the risks in related companies. On-site work is thorough and of good quality.

\section{Essential Criterion 4:Off-site work is used as a tool to:}

- regularly review and analyze the financial condition of individual banks using prudential reports, statistical returns and other appropriate information, including publicly available information;

- follow up on matters requiring further attention, evaluate developing risks and help identify the priorities and scope of further work; and

- help determine the priorities and scope of on-site work.

$\mathrm{BI}$ makes active use of information provided in prudential returns. The information is thoroughly vetted and visits to the supervised institutions may take place to understand better the context of the information and check its validity. Prudential returns are actively used in the supervision process and to develop and refine the individual supervisory strategies for each institution.

Essential Criterion 5: Based on the risk profile of individual banks, the supervisor maintains sufficiently frequent contacts as appropriate with the bank's Board, nonexecutive directors, Audit Committee and senior and middle management (including heads 


\begin{tabular}{|c|c|}
\hline & $\begin{array}{l}\text { of individual business units and control functions) to develop an understanding of and } \\
\text { assess such matters as strategy, group structure, corporate governance, performance, } \\
\text { capital adequacy, liquidity, asset quality and risk management systems. }\end{array}$ \\
\hline & $\begin{array}{l}\text { The } \mathrm{BI} \text { is not shy in establishing and maintaining supervisory contact with the institutions } \\
\text { under its charge. The range of communication is tailored to the objective, but } \mathrm{BI} \text { meets at } \\
\text { least yearly with the Board of Commissioners and more frequently with managers and } \\
\text { staff. }\end{array}$ \\
\hline & $\begin{array}{l}\text { Essential Criterion 6: On an ongoing basis during on-site and off-site supervisory } \\
\text { activities, the supervisor considers the quality of the Board and management. }\end{array}$ \\
\hline & $\begin{array}{l}\mathrm{Bl} \text { is continually assessing the quality of management and the capability and capacity of } \\
\text { members of the Board of Commissioners. }\end{array}$ \\
\hline & $\begin{array}{l}\text { Essential Criterion 7: The supervisor evaluates the work of the bank's internal audit } \\
\text { function, and determines whether, and to what extent, it may rely on the internal auditors' } \\
\text { work to identify areas of potential risk. }\end{array}$ \\
\hline & $\begin{array}{l}\text { BI does not assess the internal control function as a separate function. It is generally } \\
\text { assessed indirectly on a piecemeal basis with reference to the relevant internal control } \\
\text { systems as and when a bank approaches the BI for approval to launch a new product or } \\
\text { when BI undertakes on-site visits. The supervisors rely on the internal audit work in } \\
\text { specific areas. }\end{array}$ \\
\hline & $\begin{array}{l}\text { Essential Criterion 8: The supervisor communicates to the bank the findings of its on- } \\
\text { and off-site supervisory analyses by means of written reports or through discussions or } \\
\text { meetings with management. }\end{array}$ \\
\hline & $\begin{array}{l}\text { BI meets with the Board of Commissioners at least yearly. Communication with the bank } \\
\text { staff and management is usually in writing, and a summary of any meeting with a financial } \\
\text { institution is produced and shared where prudent. }\end{array}$ \\
\hline Assessment & Largely Compliant \\
\hline Comments & $\begin{array}{l}\text { Formal information sharing arrangements with other financial sector supervisory } \\
\text { authorities would benefit and enhance the effectiveness of the bank supervision program. } \\
\text { The absence of effective legal protection dampens supervisors' willingness to make } \\
\text { decisions and deviate from accepted methods listed in the manual. Thus, Bl's efforts to } \\
\text { encourage supervisors to use more judgment rather than rely on outputs such as SIMWAS } \\
\text { may turn out to be disappointing. Here again, specific MOUs with other domestic } \\
\text { supervisory agencies would enhance the risk based supervision program. }\end{array}$ \\
\hline Principle 21 & $\begin{array}{l}\text { Supervisory reporting Supervisors must have a means of collecting, reviewing and } \\
\text { analyzing prudential reports and statistical returns from banks on both a solo and a } \\
\text { consolidated basis, and a means of independent verification of these reports, through } \\
\text { either on-site examinations or use of external experts. }\end{array}$ \\
\hline Description & $\begin{array}{l}\text { Essential Criterion 1: The supervisor has the power to require banks to submit } \\
\text { information, on both a solo and a consolidated basis, on their financial condition, } \\
\text { performance, and risks, at regular intervals. These reports provide information on such } \\
\text { matters as on- and off-balance sheet assets and liabilities, profit and loss, capital } \\
\text { adequacy, liquidity, large exposures, asset concentrations (including by economic sector, }\end{array}$ \\
\hline
\end{tabular}


geography and currency), asset quality, loan loss provisioning, related party transactions, interest rate risk and market risk.

Article 28 of the $\mathrm{BI}$ Act requires banks to submit detailed information covering the full and complete range of prudential risks. Banks are required to submit weekly, monthly, quarterly, and annual reports. Where pertinent, such information applies to the bank, subsidiaries, and related or affiliated counterparties. Banks submit both solo and consolidated information.

Essential Criterion 2: The supervisor provides report instructions that clearly describe the accounting standards to be used in preparing supervisory reports. Such standards are based on accounting principles and rules that are widely accepted internationally.

Detailed instructions are part of the reporting regime. Banks file according to standards based on the PSAK relevant to banks, and PAPI. The new accounting standards (aligned with IAS 32 and IAS 39) are being introduced and will need to be monitored to ensure consistency and timeliness.

Essential Criterion 3: The supervisor requires banks to utilize valuation rules that are consistent, realistic and prudent, taking account of current values where relevant.

The $\mathrm{BI}$ regulations and accounting standards use consistent standards.

Essential Criterion 4: The supervisor collects and analyzes information from banks at a frequency (e.g. monthly, quarterly and annually) commensurate with the nature of the information requested, and the size, activities and risk profile of the individual bank.

$\mathrm{BI}$ requires weekly, monthly, quarterly, and annual returns. They are required of all banks and are analyzed in a timely and useful manner.

Essential Criterion 5: In order to make meaningful comparisons between banks and banking groups, the supervisor collects data from all banks and all relevant entities covered by consolidated supervision on a comparable basis and related to the same dates (stock data) and periods (flow data).

The prudential returns include all banks and are filed using consistent dates. Banks file on a solo and consolidated basis.

Areas where there is scope for improvement in supervisory reporting include triggering of contingency funding plans or liquidity pressures, significant operational risk events, country/ transfer risk, and IRRBB.

Essential Criterion 6: The supervisor has the power to request and receive any relevant information from banks, as well as any of their related companies, irrespective of their activities, where the supervisor believes that it is material to the financial situation of the bank or banking group, or to the assessment of the risks of the bank or banking group. This includes internal management information.

$\mathrm{BI}$ has the power to request information about all related parties, affiliates, and subsidiaries. There are no significant impediments to the collection of data.

Essential Criterion 7 : The supervisor has the power of full access to all bank records for the furtherance of supervisory work. The supervisor also has similar access to the bank's 


\begin{tabular}{|c|c|}
\hline & Board, management and staff, when required. \\
\hline & BI has full and complete access. \\
\hline & $\begin{array}{l}\text { Essential Criterion 8: The supervisor has a means of enforcing compliance with the } \\
\text { requirement that the information be submitted on a timely and accurate basis. The } \\
\text { supervisor determines that the appropriate level of senior management is responsible for } \\
\text { the accuracy of supervisory returns, can impose penalties for misreporting and persistent } \\
\text { errors, and can require that inaccurate information be amended. }\end{array}$ \\
\hline & $\begin{array}{l}\text { BI has full powers to ensure compliance and to hold management responsible for timely } \\
\text { and accurate reporting. }\end{array}$ \\
\hline & $\begin{array}{l}\text { Essential Criterion 9: The supervisor utilizes policies and processes to confirm the } \\
\text { validity and integrity of supervisory information. This includes a programme for the periodic } \\
\text { verification of supervisory returns by means either of the supervisor's own staff or of } \\
\text { external experts. }\end{array}$ \\
\hline & External auditors as well as $\mathrm{BI}$ staff check regulatory filings. \\
\hline & $\begin{array}{l}\text { Essential Criterion 10: The supervisor clearly defines and documents the roles and } \\
\text { responsibilities of external experts, including the scope of the work, when they are } \\
\text { appointed to conduct supervisory tasks and monitors the quality of the work. External } \\
\text { experts may be utilized for routine validation or to examine specific aspects of banks' } \\
\text { operations. }\end{array}$ \\
\hline & $\begin{array}{l}\text { Bank Indonesia Regulation 2/22/PBI/2001 provides guidance with respect to the } \\
\text { qualifications of a public accountant conducting bank audits. The accountant must be } \\
\text { registered with BI. Provisions of the BI Act allow utilization of external experts for } \\
\text { supervisory tasks. }\end{array}$ \\
\hline & $\begin{array}{l}\text { Essential Criterion 11: The supervisor requires that external experts bring to its attention } \\
\text { promptly any material shortcomings identified during the course of any work undertaken by } \\
\text { them for supervisory purposes. }\end{array}$ \\
\hline & $\begin{array}{l}\text { When external auditors detect a violation of banking or financial regulations or become } \\
\text { aware of any condition that threatens the bank's viability, they must report such incidents } \\
\text { to BI within } 7 \text { days. }\end{array}$ \\
\hline Assessment & Largely Compliant \\
\hline Comments & $\begin{array}{l}\text { BI should consider requiring banks to report on a solo and consolidated basis in respect of } \\
\text { all areas of major risks. BI needs to introduce more consistency into consolidated } \\
\text { supervision for banks. Techniques used by the supervisors vary but appear effective for } \\
\text { the most part. While the off-site reports are used well at the single institution level, they are } \\
\text { not fully utilized to generate efficient system trends and useful peer group analysis. Peer } \\
\text { group analysis is not always efficient and useful. One team reported using a peer group of } \\
\text { two to supervise a very small bank. It appears the team was following standard protocol } \\
\text { even though the actual usefulness of the exercise was highly suspect. At some point, a } \\
\text { horizontal examination of a cross-section of banks may be useful to make comparisons } \\
\text { and spread best practices throughout the industry. }\end{array}$ \\
\hline Principle 22 & $\begin{array}{l}\text { Accounting and disclosure. Supervisors must be satisfied that each bank maintains } \\
\text { adequate records drawn up in accordance with accounting policies and practices that }\end{array}$ \\
\hline
\end{tabular}




\begin{tabular}{|c|c|}
\hline & $\begin{array}{l}\text { are widely accepted internationally, and publishes, on a regular basis, information that } \\
\text { fairly reflects its financial condition and profitability. }\end{array}$ \\
\hline \multirow[t]{10}{*}{ Description } & $\begin{array}{l}\text { Essential Criterion 1: The supervisor has the power to hold bank management and the } \\
\text { bank's Board responsible for ensuring that financial record-keeping systems and the data } \\
\text { they produce are reliable. }\end{array}$ \\
\hline & $\mathrm{BI}$ has a range of sanctions available. \\
\hline & $\begin{array}{l}\text { Essential Criterion 2: The supervisor has the power to hold bank management and the } \\
\text { bank's Board responsible for ensuring that the financial statements issued annually to the } \\
\text { public receive proper external verification and bear an external auditor's opinion. }\end{array}$ \\
\hline & $\begin{array}{l}\text { Regulations require banks to have their annual financial statements audited by a public } \\
\text { accountant. BI has the power to hold management responsible. }\end{array}$ \\
\hline & $\begin{array}{l}\text { Essential Criterion 3: The supervisor requires banks to utilize valuation rules that are } \\
\text { consistent, realistic and prudent, taking account of current values where relevant, and to } \\
\text { show profits net of appropriate provisions. }\end{array}$ \\
\hline & $\begin{array}{l}\text { Financial statements must be based on PSAK and PAPI. Also, BI regulations require } \\
\text { valuation methods that are marked to market or marked to model, depending on whether } \\
\text { the instrument is traded or held to maturity. Valuation methods must account for realistic } \\
\text { changes in value based on adverse events, unavailability of trade prices or economic } \\
\text { events. In response to the market turmoil and the impact on Indonesia, the Indonesian } \\
\text { Accounting Body (DSAK-IAI), Bapepam-LK, and BI announced accounting changes } \\
\text { designed to blunt the impact. DSAK-IAI issued guidance referring to US SEC Office of the } \\
\text { Chief Accountant and FASB Staff clarification of Fair Value Accounting that allows the use } \\
\text { of other valuation techniques such as discounted cash flow. This can be applied when the } \\
\text { market price is unavailable or where market pricing is considered unrealistic. BI also } \\
\text { allowed banks to apply other valuation techniques to arrive at the fair value of treasury bills } \\
\text { whether held in trading accounts or available for sale. Banks were allowed to rearrange } \\
\text { portfolios to suit their revised intentions consistent with market conditions. As regards } \\
\text { appropriate valuation of equity participation and provisioning for NPLs, please refer to the } \\
\text { description under CP 9. }\end{array}$ \\
\hline & $\begin{array}{l}\text { Essential Criterion 4: Laws or regulations set, or the supervisor has the power, in } \\
\text { appropriate circumstances, to establish, the scope of external audits of individual banks } \\
\text { and the standards to be followed in performing such audits. }\end{array}$ \\
\hline & $\begin{array}{l}\text { BI may direct the auditors in appropriate circumstances to expand the scope of an audit } \\
\text { and may establish criteria to be used in a special audit. }\end{array}$ \\
\hline & $\begin{array}{l}\text { Essential Criterion 5: Supervisory guidelines or local auditing standards determine that } \\
\text { audits cover such areas as the loan portfolio, loan loss reserves, non-performing assets, } \\
\text { asset valuations, trading and other securities activities, derivatives, asset securitizations, } \\
\text { and the adequacy of internal controls over financial reporting. }\end{array}$ \\
\hline & $\begin{array}{l}\text { BI regulations define the minimum scope of the audit, which must cover: asset quality and } \\
\text { provisioning, other assets including foreclosed properties, all items included in Accounting } \\
\text { Guidelines for Indonesian Banks, conclusions on whether related and special party } \\
\text { transactions have been booked and executed at arm's length, exposures to related } \\
\text { parties, details on breaches of the legal lending limit, capital adequacy computations, spot } \\
\text { and derivative transactions, and other items. Auditors must report on the reliability of }\end{array}$ \\
\hline
\end{tabular}


bank's reporting to $\mathrm{BI}$ and verify the reports submitted.

Essential Criterion 6: The supervisor has the power to reject and rescind the appointment of an external auditor that is deemed to have inadequate expertise or independence, or not to be subject to or not to follow established professional standards.

Bank auditors must be approved by the BI. Banks must change auditors every five years. Auditors not meeting standards or violating standards will be delisted.

Essential Criterion 7: The supervisor requires banks to produce annual audited financial statements based on accounting principles and rules that are widely accepted internationally and have been audited in accordance with internationally accepted auditing practices and standards.

Banks are required to produce annual reports consistent with PSAK and PAPI guidelines. 23 PSAK are uniquely local standards with no counterpart in IFRS; 8 PSAK have no gaps with IFRS; 19 PSAK have minor gaps with IFRS; and 2 PSAK have moderate gaps with IFRS. Although the intention to converge local auditing standards with international standards has been expressed, no practical arrangement has yet been put in place for achieving this. Coupled with the weaknesses in standards, weaknesses in the auditing profession are also observed.

Pillar 3 implementation under the Basel II framework is still a work in process. The new accounting standards issued to facilitate the transition and convergence to internationally accepted accounting practices are targeted for full implementation in 2012. These include PSAK no. 50 and 55, which move Indonesia toward IAS 32 and 39. Continued monitoring by $\mathrm{BI}$ is warranted to ensure that standards are being realistically implemented and consistently applied in all commercial banks.

Essential Criterion 8: Laws, regulations or the supervisor require periodic public disclosures of information by banks that adequately reflect the bank's true financial condition. The requirements imposed should promote the comparability, relevance, reliability and timeliness of the information disclosed.

$\mathrm{BI}$ requirements are periodic public reporting under common guidelines promoting transparency and comparability. Despite efforts in this area, banks' financial statement reporting still varies depending on the bank. Large banks have adequate practices and follow established guidelines, but smaller commercial banks still shows signs of inconsistent reporting. Along with the weaknesses in the accounting and auditing framework, gaps in the reporting of segment information, related party transactions, consolidated financial statements, employee benefits, and derivative transactions have implications for the quality of financial statements and disclosures by banks. At present, only those banks that have a website need to publicly disclose the annual financial statements and the related disclosures. In the absence of prescribed disclosure formats, comparability of disclosures among banks is not achieved.

Despite the softening of valuation requirements announced by DSAK-IAI and BapepamLK, larger banks apparently made little use of the guidance, which will widen the gap in bank reporting rather than improving consistency.

Essential Criterion 9 : The required disclosures include both qualitative and quantitative information on a bank's financial performance, financial position, risk management strategies and practices, risk exposures, transactions with related parties, accounting policies, and basic business, management and governance. The scope and content of 


\begin{tabular}{|c|c|}
\hline & $\begin{array}{l}\text { information provided and the level of disaggregation and detail should be commensurate } \\
\text { with the size and complexity of a bank's operations. }\end{array}$ \\
\hline & $\begin{array}{l}\text { While the disclosure requirements are broadly in consonance with this criterion, there is } \\
\text { scope for improvement. With a view to improving the availability of adequate and relevant } \\
\text { information in the public domain to enable the stakeholders to make an informed } \\
\text { assessment of bank performance and to encourage aggregated analysis of banking } \\
\text { system performance, it would be ideal for } \mathrm{BI} \text { to standardize the disclosure requirements } \\
\text { and the disclosure formats for banks, covering a wider range of relevant parameters. } \\
\text { Regulations do not explicitly require banks to disclose their accounting policies and non- } \\
\text { credit transactions with related parties. }\end{array}$ \\
\hline & Please also see description under CP 11. \\
\hline & $\begin{array}{l}\text { Essential Criterion } 10 \text { : Laws, regulations or the supervisor provide effective review and } \\
\text { enforcement mechanisms designed to confirm compliance with disclosure standards. }\end{array}$ \\
\hline & BI has adequate powers. \\
\hline & $\begin{array}{l}\text { Essential Criterion 11: The supervisor or other relevant bodies publish aggregate } \\
\text { information on the banking system to facilitate public understanding of the banking system } \\
\text { and the exercise of market discipline. Such information includes aggregate data on } \\
\text { balance sheet indicators and statistical parameters that reflect the principal aspects of } \\
\text { banks' operations (balance sheet structure, capital ratios, income earning capacity, and } \\
\text { risk profiles). }\end{array}$ \\
\hline & $\begin{array}{l}\text { BI provides public data that meet the criterion on a quarterly basis. BI requires auditors to } \\
\text { report breaches of regulations and laws and other items that pertain to the safety and } \\
\text { soundness of the bank. BI publishes periodically statistical reports on banks and bank } \\
\text { supervisory reports that contain aggregate information on the banking system and limited } \\
\text { disaggregate information. There is value in increasing the scope of disclosures to cover } \\
\text { more parameters or performance indicators, improving the consistency of ratios across } \\
\text { various publications and enhancing the level of disaggregated disclosures. }\end{array}$ \\
\hline Assessment & Largely Compliant \\
\hline Comments & $\begin{array}{l}\text { In the light of the gaps and weaknesses in the accounting and auditing standards in } \\
\text { Indonesia (please see review of the preconditions for effective banking supervision - Para } \\
\text { 16), BI needs to focus more supervisory resources on ensuring that banks' financial } \\
\text { statements reflect their true financial performance and financial position. Gaps in the } \\
\text { reporting of segment information, related party transactions, consolidated financial } \\
\text { statements, employee benefits, and derivative transactions have implications for the } \\
\text { quality of disclosures by banks. Since internationally comparable accounting and reporting } \\
\text { requirements for financial instruments are not being implemented, the reported results and } \\
\text { financial condition of banks tend to be distorted. It is understood from the authorities that } \\
\text { the extent of divergences, where observed, are not significant. It would, therefore, appear } \\
\text { that the quality of audited bank financial statements is largely reliable. Further, regulation } \\
\text { and supervision need to suitably factor in these weaknesses to ensure that banks } \\
\text { adequately augment their risk management framework, particularly while relying on the } \\
\text { financial statements of their clients. }\end{array}$ \\
\hline & $\begin{array}{l}\text { BI should also develop a process to ensure a stringent quality assurance review of bank } \\
\text { audits and auditors. A review of the eligible accounting and auditing firms would be } \\
\text { relevant to ensure that only high-quality audit service providers are appointed as auditors } \\
\text { of commercial banks. BI should develop a core group with additional training to identify } \\
\text { accounting and financial reporting infractions in the financial statements of banks. }\end{array}$ \\
\hline
\end{tabular}




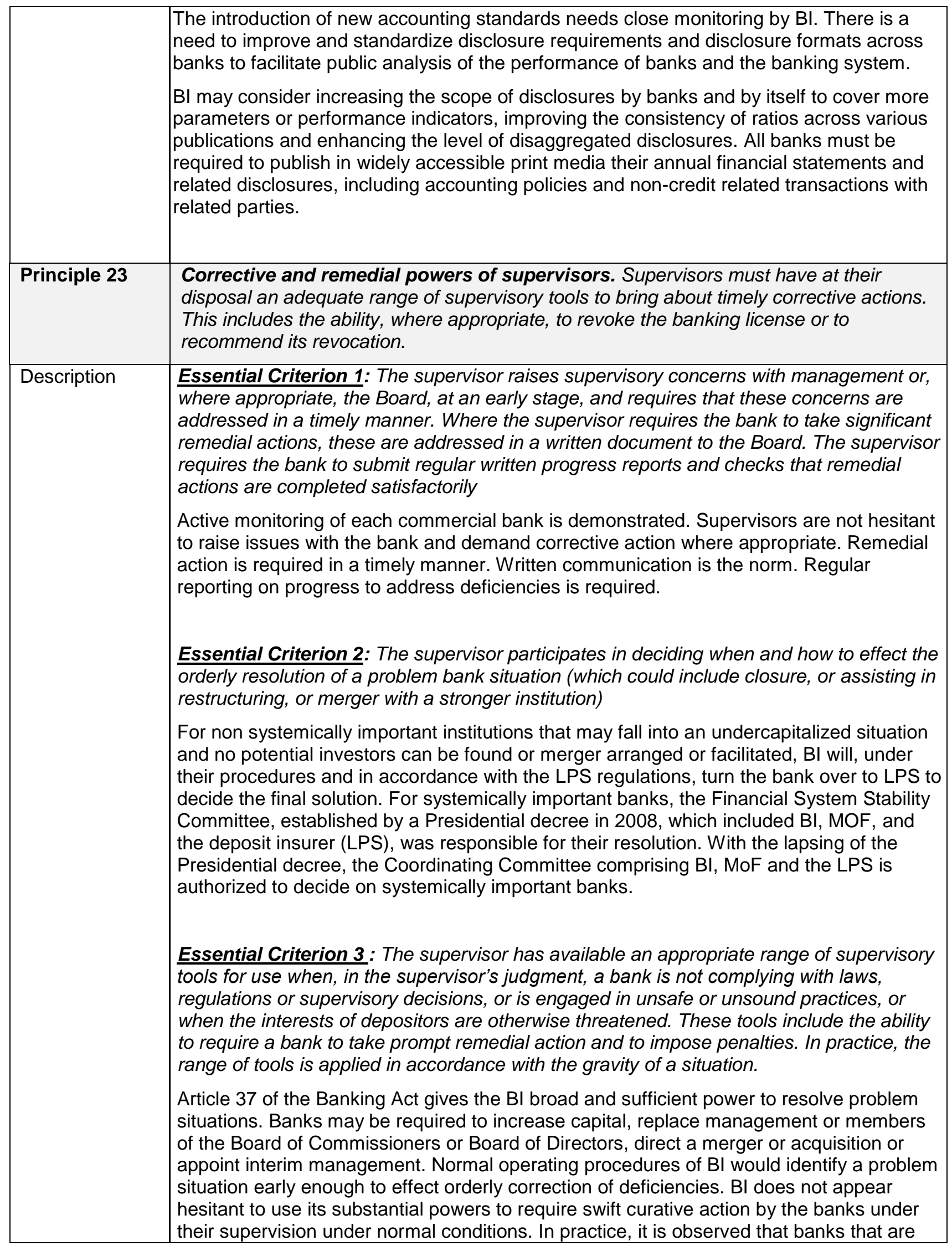




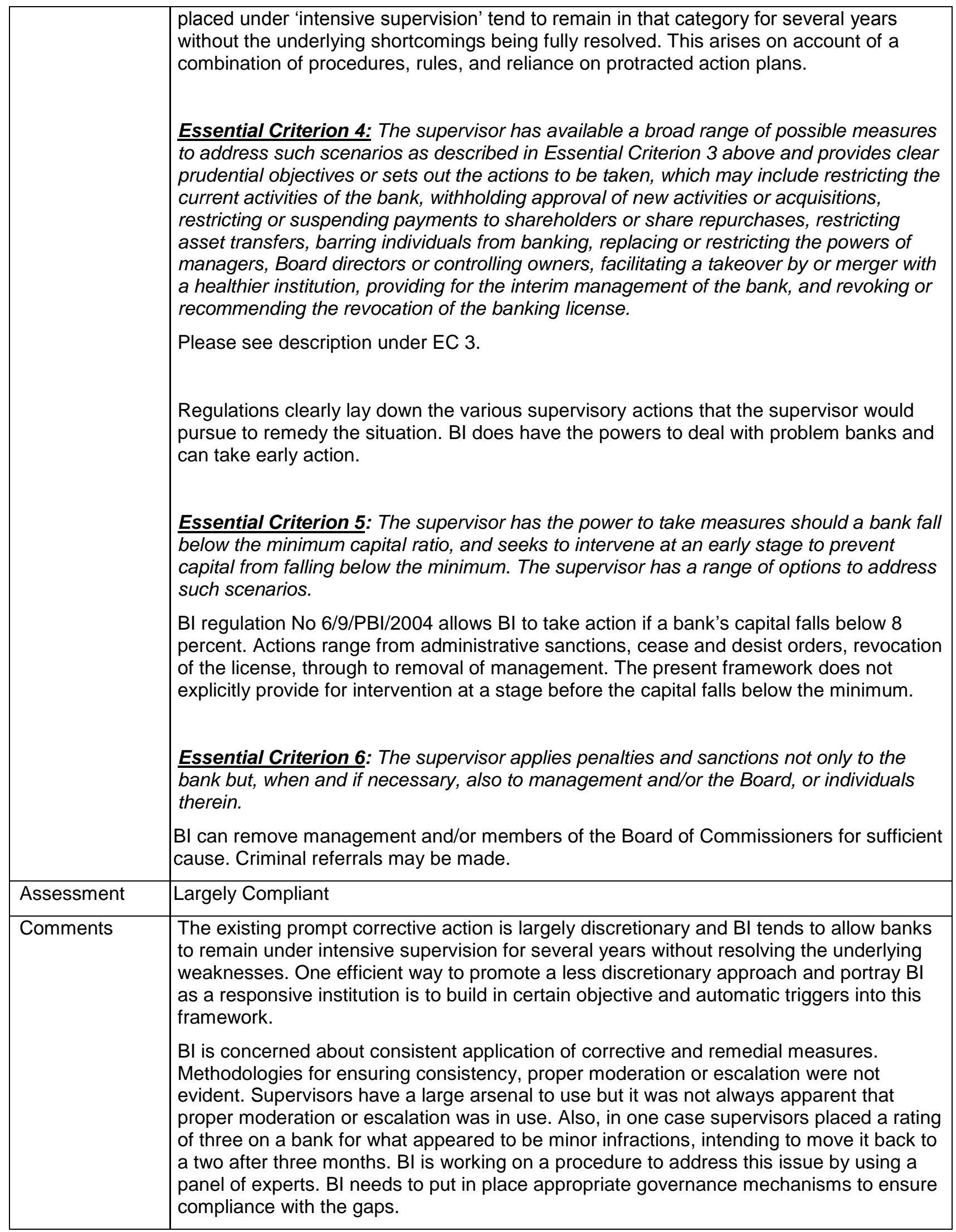




\begin{tabular}{|c|c|}
\hline Principle 24 & $\begin{array}{l}\text { Consolidated supervision. An essential element of banking supervision is that } \\
\text { supervisors supervise the banking group on a consolidated basis, adequately monitoring } \\
\text { and, as appropriate, applying prudential norms to all aspects of the business conducted } \\
\text { by the group worldwide. }\end{array}$ \\
\hline \multirow[t]{10}{*}{ Description } & $\begin{array}{l}\text { Essential Criterion 1: The supervisor is familiar with the overall structure of banking } \\
\text { groups and has an understanding of the activities of all material parts of these groups, } \\
\text { domestic and cross-border. }\end{array}$ \\
\hline & $\begin{array}{l}\text { Fourteen Indonesian banks have about } 30 \text { domestic subsidiaries (banks }-8 \text {, leasing- } 4 \text {, } \\
\text { multi-finance-8, securities- } 5 \text { and insurance-5), } 3 \text { foreign subsidiaries (bank- } 2 \text { and } \\
\text { exchange company-1) and } 10 \text { foreign branches. }\end{array}$ \\
\hline & $\begin{array}{l}\text { The scope of consolidation for supervisory purposes includes banks' subsidiaries and joint } \\
\text { ventures where the bank exercises control, but excludes (a) subsidiaries / joint ventures } \\
\text { engaged in insurance activity, (b) subsidiaries / joint ventures where banks exercise } \\
\text { control due to temporary equity participation arising on account of conversion of debt on } \\
\text { restructuring, and (c) the promoter groups or shareholders have a controlling interest in } \\
\text { the bank. }\end{array}$ \\
\hline & $\begin{array}{l}\text { BI performs its oversight through dedicated teams for each commercial bank. Supervisors } \\
\text { on the team understand the bank's organizational structure. Regulatory reports are filed on } \\
\text { a solo and consolidated basis allowing for a deeper understanding of where the } \\
\text { organization is taking risk. }\end{array}$ \\
\hline & $\begin{array}{l}\text { Essential Criterion 2: The supervisor has the power to review the overall activities of a } \\
\text { banking group, both domestic and cross-border. The supervisor has the power to } \\
\text { supervise the foreign activities of banks incorporated within its jurisdiction. }\end{array}$ \\
\hline & $\begin{array}{l}\text { Articles } 28 \text { and } 29 \text { of the } \mathrm{BI} \text { Act empower } \mathrm{BI} \text { to undertake off-site and on-site supervision } \\
\text { of the banking group, both domestic and cross-border subsidiaries and joint ventures. BI } \\
\text { regulation 8/6/PBI/2006 requires implementation of consolidated risk management } \\
\text { principles for banks owning and controlling financial subsidiaries. Though banks are not } \\
\text { allowed to own non-financial companies, banks can hold equity in non-financial entities } \\
\text { through the temporary equity participation route, and these entities are not consolidated } \\
\text { for supervisory purposes. }\end{array}$ \\
\hline & $\begin{array}{l}\text { Essential Criterion } 3 \text { : The supervisor has a supervisory framework that evaluates the } \\
\text { risks that non-banking activities conducted by a bank or banking group may pose to the } \\
\text { bank or banking group. }\end{array}$ \\
\hline & $\begin{array}{l}\text { The supervisory framework for consolidated supervision relies primarily on periodic off-site } \\
\text { reports that are submitted on a solo as well as consolidated basis. These include reports } \\
\text { on the financial position, reports aimed at verifying compliance with prudential } \\
\text { requirements and the risk profile. On-site examinations include, where necessary and } \\
\text { prudent, examinations of risk taking in the bank as well as its subsidiaries. }\end{array}$ \\
\hline & $\begin{array}{l}\text { As mentioned under EC } 1 \text { and } 2 \text {, banks are not allowed to own non financial entities. } \\
\text { However, the risks from non financial activities can pose a risk to the bank through the } \\
\text { parent company or controlling shareholders and also through the temporary equity } \\
\text { participation route. The present scope of consolidated supervision excludes risks from } \\
\text { non-financial activities as well as insurance subsidiaries. }\end{array}$ \\
\hline & $\begin{array}{l}\text { Essential Criterion 4: The supervisor has the power to impose prudential standards on a } \\
\text { consolidated basis for the banking group. The supervisor uses its power to establish } \\
\text { prudential standards on a consolidated basis to cover such areas as capital adequacy, }\end{array}$ \\
\hline
\end{tabular}


large exposures, exposures to related parties and lending limits. The supervisor collects consolidated financial information for each banking group.

Prudential norms that are applied on a consolidated basis include capital adequacy, legal lending limits (including related party exposures), and asset quality and provisioning. BI requires financial statements to be filed on both a solo and consolidated basis. Regulatory reports on capital adequacy, legal lending limits, asset quality, and provisioning are likewise filed on a solo and consolidated basis, subject to the exclusion of group entities mentioned under EC 1.

Supervision teams have a good understanding of how the bank is managing its risk groupwide and will include the activities of the subsidiary, when and if necessary, in the scope of the on-site examination. In the absence of a specific framework for consolidated supervision, techniques and approaches can differ among the teams.

Essential Criterion 5: The supervisor has arrangements with other relevant supervisors, domestic and cross-border, to receive information on the financial condition and adequacy of risk management and controls of the different entities of the banking group.

Other than an MOU with the deposit insurer, there is no arrangement for information sharing with other relevant domestic supervisors. To deal with this problem the $\mathrm{BI}$ relies on the off-site consolidated reports and where considered necessary on on-site assessments, to understand, monitor, and supervise risk taking in the whole group. BI does not have arrangements with foreign supervisors for an ongoing exchange of information on the foreign operations of Indonesian banks and their subsidiaries. In the absence of both formal and informal arrangements, ongoing information sharing and coordination with the other supervisors (domestic and foreign) is largely ad-hoc.

Essential Criterion 6: The supervisor has the power to limit the range of activities the consolidated group may conduct and the locations in which activities can be conducted; the supervisor uses this power to determine that the activities are properly supervised and that the safety and soundness of the bank are not compromised.

Banks must apply for permission for new acquisitions or investments in the equity of financial entities. The equity investments undertaken by group entities do not come within the purview of $\mathrm{BI}$ regulations.

While the $\mathrm{BI}$ regulations requiring banks to obtain prior approval for selling some products apply at the solo level, these do not apply to the group entities. Thus, the BI may not be well placed to restrict ex-ante the range of activities or locations from which activities may be undertaken by group entities, but is equipped to require compliance ex-post when these activities pose a threat to the soundness of the bank.

Essential Criterion 7: The supervisor determines that management is maintaining proper oversight of the bank's foreign operations, including branches, joint ventures and subsidiaries. The supervisor also determines that banks' policies and processes ensure that the local management of any cross-border operations has the necessary expertise to manage those operations in a safe and sound manner and in compliance with supervisory and regulatory requirements.

Off-site supervisory focus is largely on banks' solo and consolidated financial positions as well as the prudential requirements. The on-site visits to banks tend to focus on certain elements of the domestic operations identified during the course of off-site supervision. Foreign operations of the Indonesian banks receive less supervisory attention, unless BI 
goes on-site to these locations. BI pays limited attention to the oversight of the foreign operations by the bank's management.

$\mathrm{BI}$ has conducted on-site examinations of overseas offices of Indonesian banks such as a money changing company located in Hong Kong. Examinations of overseas operations are mostly conducted as part of the yearly examination. Five of the ten foreign branches of Indonesian banks are in the Cayman Islands. The reasons for maintaining these offices in many cases were not clear. Although gathering of funds is cited as the reason, the branch bookings are mostly small. The total assets of the foreign operations (branches and subsidiaries) range from less than 1 percent to about 9 percent of the group assets of the respective banks.

Essential Criterion 8: The supervisor determines that oversight of a bank's foreign operations by management (of the parent bank or head office and, where relevant, the holding company) includes: (i) information reporting on its foreign operations that is adequate in scope and frequency to manage their overall risk profile and is periodically verified; (ii) assessing in an appropriate manner compliance with internal controls; and (iii) ensuring effective local oversight of foreign operations.

For the purposes of consolidated risk management and supervision, there should be no hindrance in host countries for the parent bank to have access to all the material information from their foreign branches and subsidiaries. Transmission of such information is on the understanding that the parent bank itself undertakes to maintain the confidentiality of the data submitted and to make them available only to the parent supervisory authority.

(Please see description under EC 7)

Indonesian banks are able to have access to all relevant information pertaining to their overseas subsidiaries and branches that is required by $\mathrm{BI}$.

Essential Criterion 9: The home supervisor has the power to require the closing of foreign offices, or to impose limitations on their activities, if:

I. it determines that oversight by the bank and/or supervision by the host supervisor is not adequate relative to the risks the office presents; and/or

I. it cannot gain access to the information required for the exercise of supervision on a consolidated basis.

$\mathrm{BI}$ has the authority to require closure or otherwise impose restrictions or limitations on foreign offices if it believes there are not adequate controls in place or information impediments exist.

Essential Criterion 10: The supervisor confirms that oversight of a bank's foreign operations by management (of the parent bank or head office and, where relevant, the holding company) is particularly close when the foreign activities have a higher risk profile or when the operations are conducted in jurisdictions or under supervisory regimes differing fundamentally from those of the bank's home country.

(Please see description under EC 7 also)

BI does not have a uniform policy in place regarding the supervision of foreign branches of Indonesian banks. The most significant risk for the foreign branches and subsidiaries is counterparty risk especially as it relates to ensuring correspondent banks have robust 


\begin{tabular}{|c|c|}
\hline & $\begin{array}{l}\text { AML procedures in place. BI should develop a policy for supervision of banks' overseas } \\
\text { operations, including foreign branches, and ensure compliance. }\end{array}$ \\
\hline Assessment & Largely Compliant \\
\hline \multirow[t]{11}{*}{ Comments } & $\begin{array}{l}\text { BI has taken steps from an accounting, regulatory and supervisory perspective to improve } \\
\text { consolidated oversight of the banking system. The supervisory team members are fully } \\
\text { knowledgeable on the consolidated risks of each banking organization and design } \\
\text { supervisory exercises aimed at covering the constellation of risks in each financial group. } \\
\text { Consolidated supervision is being accomplished largely by BI taking responsibility for on- } \\
\text { site supervision of the consolidated organization to cover for other financial regulators } \\
\text { where routine robust examinations are not a part of the supervisory process. Lack of } \\
\text { formal arrangements to transfer information between domestic supervisors, combined with } \\
\text { weaknesses in the supervision of overseas branches, is an impediment to effective } \\
\text { consolidated supervision and falls short of addressing adequately the thrust of }\end{array}$ \\
\hline & EC 5. \\
\hline & $\begin{array}{l}\text { While BI has made good progress in exercising consolidated supervision, several areas } \\
\text { where there are gaps or scope for improvement are: }\end{array}$ \\
\hline & $\begin{array}{l}\text { a) Exclusions (cited under EC 1) from the scope of consolidated supervision can } \\
\text { expose the banks to risks that are at present outside the supervisory radar. }\end{array}$ \\
\hline & $\begin{array}{l}\text { b) Regulations on equity participation and the sale of structured products do not } \\
\text { apply to the consolidated bank, thereby providing other channels through which } \\
\text { banks may be impacted by risks from the group entities. }\end{array}$ \\
\hline & $\begin{array}{l}\text { The lack of formal and informal gateways for ongoing information exchange can } \\
\text { be a serious issue. Consolidated supervision is best accomplished on a } \\
\text { relationship basis, and frequent contact with other domestic supervisors and host } \\
\text { supervisors is an important element in building trust among supervisors. }\end{array}$ \\
\hline & $\begin{array}{l}\text { d) With respect to Indonesian banks' overseas branches, there was no specific } \\
\text { framework to determine when and how often these offshore activities should be } \\
\text { examined. The money changing operations of an Indonesian bank were examined } \\
\text { on-site in Hong Kong, but there were far more significant foreign operations that } \\
\text { might have received attention. }\end{array}$ \\
\hline & \\
\hline & \\
\hline & $\begin{array}{l}\text { g) The absence of a specific framework for consolidated supervision can lead to } \\
\text { differing techniques and approaches among the supervisory teams. }\end{array}$ \\
\hline & $\begin{array}{l}\text { BI needs to enhance the scope of consolidation, promote consistency in the application of } \\
\text { consolidated supervision, and develop effective operating arrangements for information } \\
\text { sharing and coordination with the relevant supervisors (domestic and foreign). }\end{array}$ \\
\hline Principle 25 & $\begin{array}{l}\text { Home-host relationships. Cross-border consolidated supervision requires cooperation } \\
\text { and information exchange between home supervisors and the various other supervisors } \\
\text { involved, primarily host banking supervisors. Banking supervisors must require the local } \\
\text { operations of foreign banks to be conducted to the same standards as those required of } \\
\text { domestic institutions. }\end{array}$ \\
\hline \multirow[t]{2}{*}{ Description } & $\begin{array}{l}\text { Essential Criteria } 1 \text { Information to be exchanged by home and host supervisors should } \\
\text { be adequate for their respective roles and responsibilities. }\end{array}$ \\
\hline & $\begin{array}{l}\text { BI has no arrangements in place for information exchange with home supervisors of } \\
\text { systemically relevant foreign financial institutions. For legal reasons, many jurisdictions } \\
\text { can only provide supervisory information to a host country if a formal information exchange } \\
\text { agreement is in place. This could place BI at a significant disadvantage should a home }\end{array}$ \\
\hline
\end{tabular}


supervisor feel it necessary to inform host supervisors of problems developing at the parent bank or concerns about controls.

As foreign banks have a large and growing share of the Indonesian market, BI must develop better procedures for dealing with home country authorities. BI should identify those foreign institutions that pose a systemically relevant threat to the market and arrange a supervisory process that deals adequately with the issue.

Essential Criterion 2 : For material cross-border operations of its banks, the supervisor identifies all other relevant supervisors and establishes informal or formal arrangements (such as memoranda of understanding) for appropriate information sharing, on a confidential basis, on the financial condition and performance of such operations in the home or host country. Where formal cooperation arrangements are agreed, their existence should be communicated to the banks and banking groups affected.

Besides the exchange of information with neighboring supervisors, there are no formal or informal arrangements in place for effective ongoing home to host communication and vice versa.

Essential Criterion 3: The home supervisor provides information to host supervisors, on a timely basis, concerning:

- the overall framework of supervision in which the banking group operates;

- the bank or banking group, to allow a proper perspective of the activities conducted within the host country's borders;

- the specific operations in the host country; and

- $\quad$ where possible and appropriate, significant problems arising in the head office or other parts of the banking group if these are likely to have a material effect on the safety and soundness of subsidiaries or branches in host countries.

A minimum level of information on the bank or banking group will be needed in most circumstances, but the overall frequency and scope of this information will vary depending on the materiality of a bank's or banking group's activities to the financial sector of the host country. In this context, the host supervisor will inform the home supervisor when a local operation is material to the financial sector of the host country.

There is no proper protocol to deal with the home supervisors of systemically relevant foreign bank operations in Indonesia either through branches or locally incorporated subsidiaries.

Essential Criterion 4:The host supervisor provides information to home supervisors, on a timely basis, concerning:

- material or persistent non-compliance with relevant supervisory requirements, such as capital ratios or operational limits, specifically applied to a bank's operations in the host country;

- adverse or potentially adverse developments in the local operations of a bank or banking group regulated by the home supervisor;

- adverse assessments of such qualitative aspects of a bank's operations as risk management and controls at the offices in the host country; and

- any material remedial action it takes regarding the operations of a bank 
regulated by the home supervisor.

A minimum level of information on the bank or banking group, including the overall supervisory framework in which they operate, will be needed in most circumstances, but the overall frequency and scope of this information will vary depending on the materiality of the cross-border operations to the bank or banking group and financial sector of the home country. In this context, the home supervisor will inform the host supervisor when the cross-border operation is material to the bank or banking group and financial sector of the home country

$\mathrm{BI}$ has a policy of informal communication with host supervisors during the conduct of an examination in an overseas jurisdiction. Information will be exchanged on the condition of the local office being examined. Likewise, when a foreign supervisor visits Indonesia to examine a local entity, informal exchanges of information take place.

The recent global events have created cause for concern about the health of some foreign banks operating in Indonesia. BI did take initial steps to determine the degree of the threat posed to local operations and initiated a letter to the home supervisor inquiring about the steps they were taking to deal with the problem. Whether caused by the lack of formal information sharing agreement or the policy of the home supervisor, the response received was less than candid and provided little assistance in answering the larger question of what steps $\mathrm{BI}$ should take to protect local depositors and creditors.

BI needs to take a careful look at its present policy.

Essential Criterion 5: A host supervisor's national laws or regulations require that the cross-border operations of foreign banks are subject to prudential, inspection and regulatory reporting requirements similar to those for domestic banks.

The national laws do not make exceptions for foreign banks. In practice, there is equality of prudential requirements. The sole exception can be the operation of the single presence policy, which does not allow foreign investors to hold a stake in two banks. However, foreign banks are allowed to operate a branch of the parent bank and also hold a controlling stake in a domestic bank.

Essential Criterion 6: Before issuing a license, the host supervisor establishes that no objection (or a statement of no objection) from the home supervisor has been received. For purposes of the licensing process, as well as ongoing supervision of cross-border banking operations in its country, the host supervisor assesses whether the home supervisor practises global consolidated supervision.

$\mathrm{BI}$ licensing procedures require a no-objection letter from home supervisors, and information is requested on the fit and proper qualifications of local management if they are seconded from head office. No formal assessment of whether consolidated supervision is practiced in the home country is undertaken, but most of the offices are from jurisdictions with good supervisory practices that include consolidated supervision.

Essential Criterion 7: Home country supervisors are given on-site access to local offices and subsidiaries of a banking group in order to facilitate their assessment of the group's safety and soundness and compliance with KYC requirements. Home supervisors should inform host supervisors of intended visits to local offices and subsidiaries of banking groups.

Examination rights are permitted if the home country allows Indonesia to examine offices in their jurisdiction. 


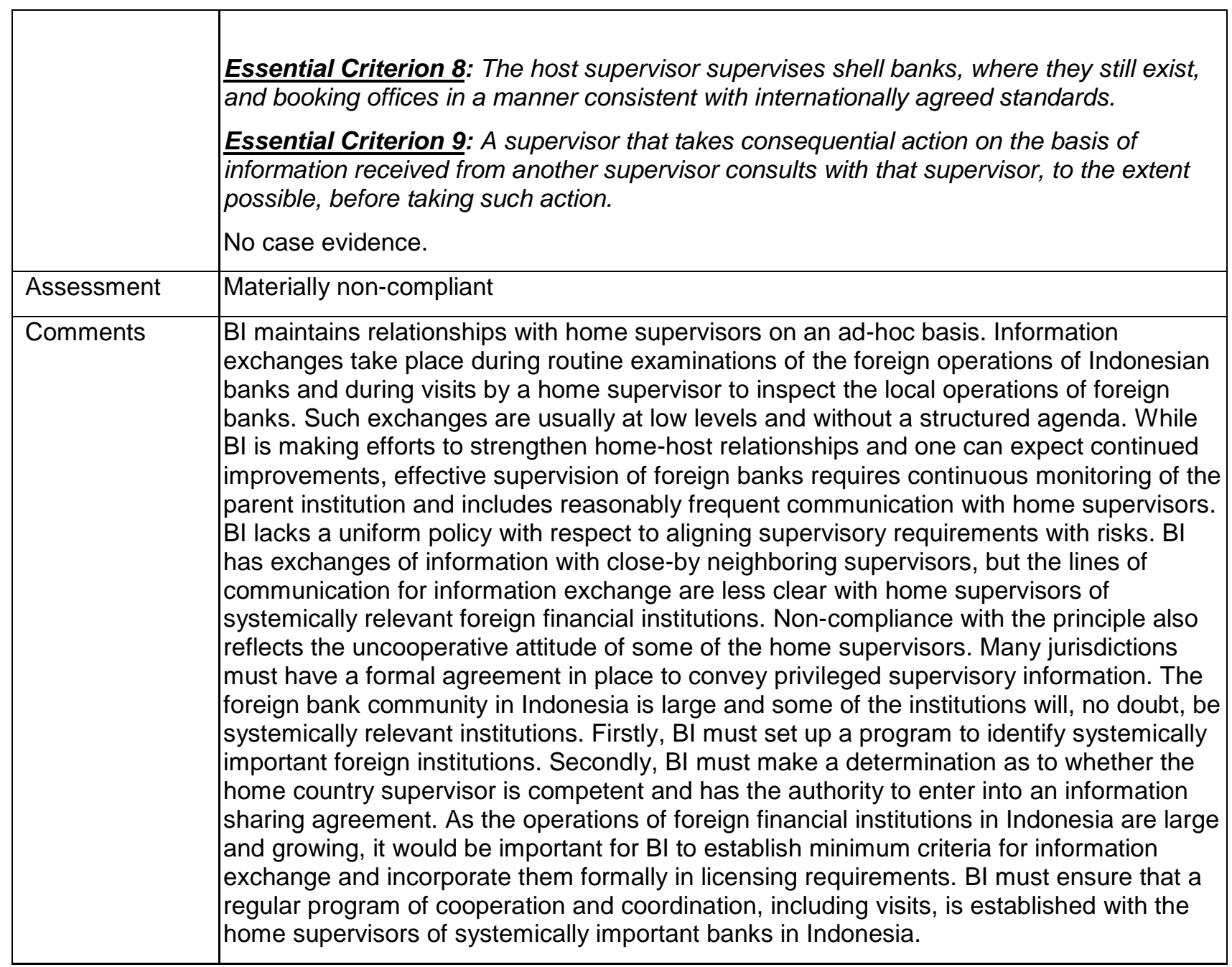

